\title{
Consequences of Postulated Losses of LWR Spent Fuel and Plutonium Shipping Packages at Sea
}

October 1977

Prepared for the

U.S. Department of Energy

under Contract EY-76-C-06-1830 


\title{
NOTICE
}

This report was prepared as an account of work sponsored by the United States Government. Neither the United States nor the Department of Energy, nor any of their employees, nor any of their contractors. subcontractors, or their employees, makes any warranty, express or implied, or assumes any legal liability or tesponsibility for the accuracy, completeness or usefuiness of any information, apparatus, product or process disciosed, or represents that its use would not infringe privately owned rights.

The views, opinions and conclusions contained in this report are those of the contractor and do not necessarily represent those of the United States Government or the United States Department of Energy.

\author{
PACIFIC NORTHWEST LABORATORY \\ operated by \\ BATTELLLE \\ for the \\ UNITED STATES DEPARTMENT OF ENERGY \\ Under Contract EY-76-C-06-1830
}

\author{
Printed in the United 5 tates of America \\ Avaitable trom \\ National Technical Information Service \\ United States Department of Commerce \\ 5285 Port Royal Road \\ Springfield, Virginia 22151
}

Price: Printed Copy 5 ; Microfiche $\$ 3.00$

$\begin{array}{cc}\text { PPages } & \text { NTIS } \\ \text { Selling Price } \\ 001-025 & 54.50 \\ 026-050 & 55.00 \\ 051-075 & 55.50 \\ 076-100 & 56.00 \\ 101-125 & \$ 5.50 \\ 126-150 & 57.00 \\ 151-175 & 57.75 \\ 176-200 & 58.50 \\ 201-225 & \$ 8.75 \\ 126-250 & 59.00 \\ 251-275 & 510.00 \\ 275-300 & 510.25 \\ \end{array}$


by

S. W. Heaberl in

D. A. Baker

C. E. Beyer

J. R. Friley

S. Mandel

P. L. Peterson

F. A. Simonen

October 1977

BATTELLE

Pacific Northwest Laboratories

Richland, Washington 99352 


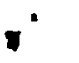




\section{ACKNOWLEDGMENTS}

The authors would like to acknowledge the assistance provided by the following: W. L. Templeton, J. K. Soldat, R. F. Foster and G. R. Schreckhise for their input to the radiological impact sections; J. F. Johnson for his assistance in the package failure area; R. J. Hall and R. E. Rhoads for overall guidance and N. M. Burleigh whose editorial skills have made this document readable. 
$\bullet$

4 


\section{CONTENTS}

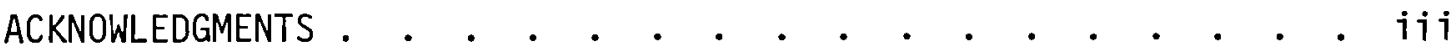

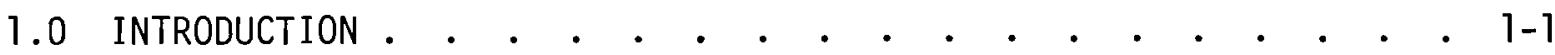

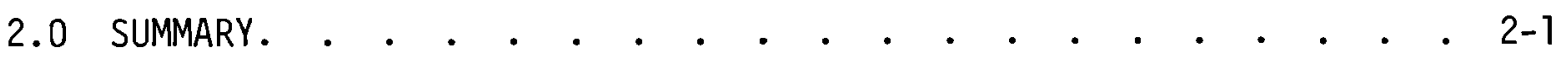

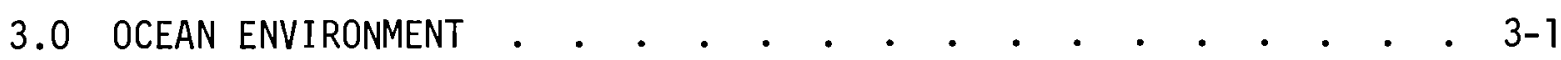

3.1 GEOLOGY AND TOPOGRAPHY OF THE OCEAN FLOOR. . . . . . • . 3-1

\begin{tabular}{l}
3.2 PROPERTIES OF THE OCEAN ENVIRONMENT THAT COULD CONTRIBUTE \\
TO PACKAGE FAILURE \\
\hline
\end{tabular}

3.3 BEHAVIOR OF RADIOACTIVE MATERIAL IN THE OCEAN • • • • • •

4.0 SHIPPING PACKAGES AND POSTULATED LOSS SCENARIOS . • • • • • • 4-

4.1 PLUTONIUM SHIPPING PACKAGE DESCRIPTION. . . . . . . . . 4-1 -

4.2 SPENT FUEL SHIPPING PACKAGE DESCRIPTION • • • • • • • . 4-2

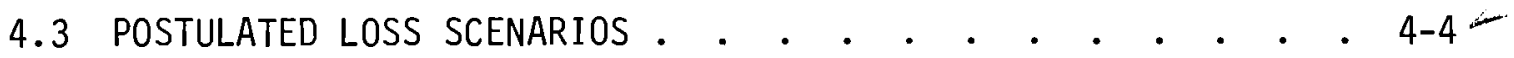

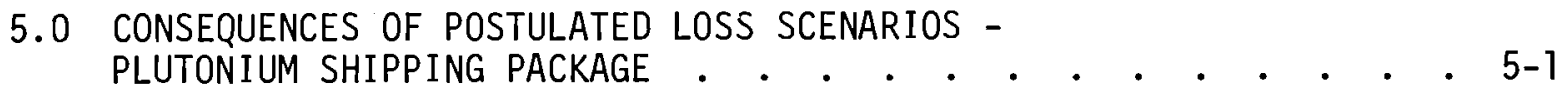

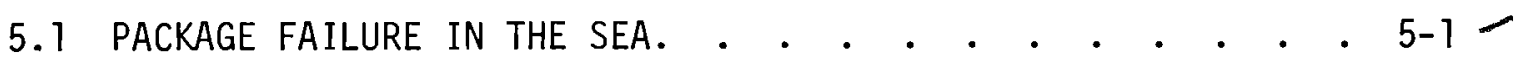

5.1.1 Plutonium Package Failure Thresholds . . . . . . 5-1

5.1 .2 Critical Failure Modes. . . . . . . . . 5-2

5.2 PLUTONIUM RELEASE FROM 6M PACKAGE . • • • • • • • • 5-3

5.3 RADIOLOGICAL IMPACT • • • • • • • • • • • • • • . 5-4

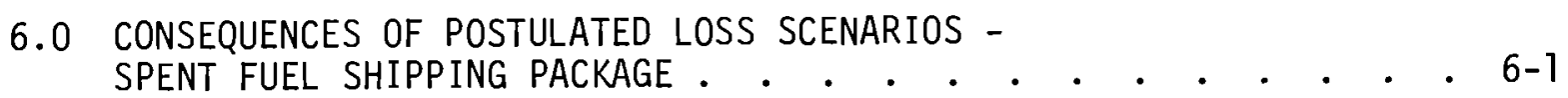

6.1 SPENT FUEL PACKAGE FAILURE THRESHOLDS . . . • . • . • . 6-1

6.1 .1 Failure Threshold of Spent Fuel Casks
by Hydrostatic Pressure . . . . . . . . 6-1

6.1.2 Failure Threshold of Spent Fuel Cask by Corrosion. . 6-2

6.1 .3 Critical Failure Modes. . . . . . . . . . 6-3 
6.2 RADIOACT IVE MATERIAL RELEASES FROM SPENT FUEL PACKAGE. • • 6-5 6.2.1 Immediate Rod Failure . . . . . . . . . 6-6 6.2.2 Delayed Rod Failure. . . . . . . . . . 6-12 6.2.3 Effect of Burial in Marine Sediments . . . . . 6-13

6.3 RADIOLOGICAL IMPACT . . . . . . . . . . . . . 6-13 7.0 OTHER CONSIDERATIONS IN THE LOSS OF PACKAGES AT SEA . . . . . 77.1 LIKELIHOOD OF LOSS . • . . . . . . . . . . . . 7-1 7.2 RECOVERY. . . . . . . . . . . . . . . . . . 7-3 APPENDIX A - FAILURE THRESHOLDS IN THE SEA . . . . . . . . . . . A-1

A. 1 FAILURE THRESHOLDS OF THE 6M PACKAGE BY HYDROSTATIC PRESSURE. . . . . . . . . . . . . . . . . A-1

A.2 FAILURE THRESHOLD OF THE 6M PACKAGE BY CORROSION . . . . A-3

A.3 FAILURE THRESHOLD OF THE SPENT FUEL CASK BY HYDROSTATIC PRESSURE. . . . . . . . . . . . . . A-4

A.3.1 Spent Fuel Cask Seals and Pressure Relief Devices. A-4 A.3.2 Spent fuel Rods . . . . . . . . . . . A-6

A.4 FAILURE THRESHOLD OF SPENT FUEL CASK BY CORROSION • • • . A-9 APPENDIX B - PACKAGE BURIAL IN MARINE SEDIMENT . . . . . . . . . B-1

B. 1 POTENTIAL OF FREE-FALLING SPENT FUEL CASK FOR BURIAL . . . B-1

B.2 THERMAL CONSIDERATIONS OF BURIAL OF SPENT FUEL CASK • • • B-6 APPENDIX C - RADIOACTIVE MATERIAL RELEASE . • • • • • • • . . c C-1

C. 1 RELEASE QUANTITIES FROM PLUTONIUM SHIPPING PACKAGE. . . . c-

C.2 RELEASE QUANTITIES FROM SPENT FUEL CASK . . . . . . . c c-1

C.3 SOLUTION TO THE BOOTH MODEL . . . . . . . . . . . C-10

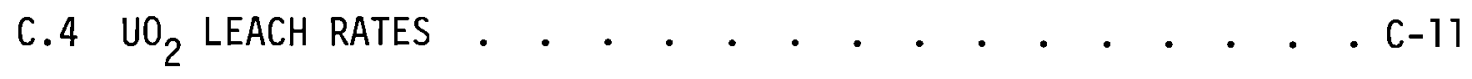
APPENDIX D - DOSE MODELING . . . . . . . . . . . . . . . . D-1 


\section{FIGURES}

3.1 Relief Map of the North Atlantic Ocean Floor . . . . . . 3-2

3.2 Relief Map of the North Pacific Ocean Floor . . . . . . 3-3

3.3 Hydrostatic Pressure versus Ocean Depth . . . . . . . . . 3-5

4.1 6M Container. . . . . . . . . . . . . . . . . . 4-1

4.2 Spent Fuel Cask . . . . . . . . . . . . . . . 4-3

6.1 Release Mechanisms for Fission Products from

Failed Spent Fuel Rod in Ocean . . . . . . . . . . 6-7

$6.2 \mathrm{UO}_{2}$ Fuel Rod . . . . . . . . . . . . . . . $6-8$

B.1 Velocity vs Fall Distance . . . . . . . . . . . B-3

C. 1 Leach Rates of Radioactive Isotopes from an Enriched $\mathrm{UO}_{2}$
Pellet Irradiated to 54,000 MWd/MTM . . . . . . C-11

C.2 Leach Rates of Radioactive Isotopes from an Enriched $\mathrm{UO}_{2}$
Pellet Irradiated to 54,000 MWd/MTM . . . . . . . C-11 



\section{TABLES}

3.1 Typical Ocean Depths along Shipping Lanes . . . . . . . 3-4

4.1 Loss Scenarios . . . . . . . . . . . . . . 4-6

5.1 Critical Failure Modes of Plutonium Package by Loss Scenario. . . . . . . . . . . . . . 5-2

5.2 Estimated Dose from Contaminated Seafood Consumption after Loss of a Single Plutonium Package at Sea . . . . . . . 5-5

6.1 Critical Failure Mode of Spent Fuel Package by Loss Scenario . . 6-4

6.2 Unique Critical Failure Modes - Spent Fuel Package . . . . . 6-5

6.3 Released Fractions of Long-Lived Gaseous and Semi-Volatile Fission Products to Gap and Fuel Surface. . . . . . . . 6-8

6.4 Estimated Dose from Contaminated Seafood Consumption after the Loss at Sea of a Spent Fuel Cask Containing 3.1 MT Uranium . . . . . . . . . . . . . . . 6-15

7.1 Summary of Merchant Ships Totally Lost: 1970 to 1974 . . . . 7-2

7.2 Summary of Merchant Ships Totally Lost and Those Lost through Fire by Size - 1974 . . . . . . . . . . . . 7-3

7.3 Ships Totally Lost 1974 by Nation of Registry . . . . . . . 7-3

7.4 Relative Effectiveness of Recovery of Lost Shipping Containers. . . . . . . . . . . . . . 7-6

A.1 Typical Material Properties and Dimensions for LWR Fuel Rods . . A-6

B. 1 Estimated Burial Depths in Representative Marine Sediments for a 73-MT Cylinder with a $1.5 \mathrm{~m}$ Diameter and a $4.9 \mathrm{~m}$ Length. . . . B-5

C.1 Plutonium Release Quantities. . . . . . . . . . . . C-2

C.2 Radioactive Isotopes Considered in This Study . . . . . . . C-2

C.3 Total Curies Released from Severe Fire . . . . . . . . . C-3

C.4 Leaching Releases after Immediate Failure by Fire - Curies. . C-4

C.5 Total Curies Released from 1000 Year Delayed Failure. . . . . C-7 
C.6 Volatile Releases from $1 \%$ Failed Fuel. . . . . . . . . . C-9

C.7 Cesium Leached from $1 \%$ Failed Rods. . . . . . . . . . C-9

D.1 Nuclide Dependent Parameters Use for Dose Calculation . . . . D-2 



\subsection{INTRODUCTION}

As the use of nuclear power expands throughout the world, the number of shipments of radioactive materials carried in ocean transport will increase. The safety of ocean transport of radioactive materials has not been systematically evaluated. However, accidents involving cargo vessels can be postulated that result in the loss of packages containing radioactive material into the sea. This study provides a preliminary assessment of the potential consequences of some specific loss scenarios involving a large Light Water Reactor spent fuel cask and a plutonium shipping package. In general, the potential consequences of the loss of one of these packages into the ocean are dependent on the damage that the package sustains in the accident prior to the 1oss. Two cases have been chosen for detailed consideration - undamaged packages and packages damaged by fire. These cases were chosen to provide information on a wide range of potential consequences. Other types of preloss damage were not considered.

The properties of the marine environment that could contribute to the failure of packages lost at sea and the behavior of radioactive materials released into the ocean are discussed in Section 3. Package failure mechanisms are postulated in Section 4 and evaluated in Sections 5 and 6.

The radiation dose to man through the marine food chain following release of the contents of a single package into the sea is estimated in Sections 5 and 6 . Other transport mechanisms, such as airborne transfer and material washing ashore, are not included in this study. Details of the analysis are contained in the appendices.

The loss of packages both on the continental shelf and in the deep ocean is considered. The accuracy of the analysis was 1 imited in many instances by the lack of a good data base. In these cases, conservative assumptions were made to permit application of existing data. A complete safety analysis of the marine transport of radioactive materials was beyond the scope of this study. Such an analysis requires detailed consideration of all identifiable accident scenarios including the likelihood of occurrence of events contributing to package failure and the consequences of each accident. Only 
potential consequences of some specific accident scenarios are considered in this study, although some preliminary information on the probability of occurrence of marine accidents is presented to lend perspective to the analysis. 


\subsection{SUMMARY}

This report estimates the potential consequences of the loss of a large spent fuel cask and of a single 6M plutonium shipping package into the sea for two specific accident cases. The radiation dose to man through the marine food chain following the loss of undamaged and fire-damayed packages to the continental sinelf and in the deep ocean have been conservatively estimated.

Two failure mecharisms that could lead to release of radioactive material after loss of packages into the ocean nave been considered. These failure mechanisms are corrosion and hydrostatic pressure. A third possible mechanism is thermal overpressurization following burial in marine sediments which is discussed in Appendix B. It w:S determined that the 6M container could release its contents due to inleakage of sea water caused by hydrostatic pressure for losses both on the continental shelf and in tie deep ocean. No significant differerce was found between fire-damaged and undamaged containers. The other failure mechanisms were determined to be unimportant for $6 \mathrm{M}$ packages.

It was determined that the seals or pressure relief devices on an undamaged spent fuel cask might fail from hydrostatic forces for losses on the continental shelf although some cask designs would retain their integrity at this depth. Most casks would likely fail in the deep ocean. Calculations predict that the fuel rods in the cask would fail from hydrostatic forces only for losses in the deep ocean. Corrosive failure of the fuel rods in casks lost to the continental shelf is estimated to require at least 2,000 years. Severely fire-damaged casks are assumed to begin releasing radioactive material immediately, regardless of loss location.

The population dose to man through the marine food chain following these scenarios has been estimated. The dose estimates are made relating the radioactive material released and the seafood productivity in the region of the release. Doses are based on a gne-yeir consumption of contaminated seafood. (Other assumptions are given in Section 3.3 and Appendix D.) The largest potential doses result from losses of a package on the continental shelf, since this area has the greatest seafood productivity. The loss of a 
single plutonium package on the continental shelf is estimated to produce a population dose commitment of less than 250 man-rem for recycle plutonium. The dose commitment to the average individual is less than one millirem. The calculated dose commitment for the loss of an extremely fire-damaged spent fuel cask on the continental shelf is estimated as 150,000 man-rem. The average individual receives approximately $170 \mathrm{millirem}$ in this case. Doses for losses of undamaged casks to the continental shelf and deep ocean and for loss of a fire-damaged cask to the deep ocean were determined to be several orders of magnitude smaller.

A11 dose calculations have been made in a conservative manner. No credit was taken for several factors that could reduce the potential dose such as restricting fishing in the area of the accident. The technology exists for location and recovery of the packages. A successful recovery operation could considerably reduce the size of some releases and eliminate others almost completely. 


\subsection{OCEAN ENVIRONMENT}

The characteristics of the ocean environment that are important in evaluating the consequences of the loss of radioactive materials in the sea are presented in this section. The geological and topographical features of the ocean floor are discussed in Section 3.1. Section 3.2 describes the hydrostatic forces and corrosion environment experienced by a shipping package lost in the ocean. The behavior of free radioactive material in the ocean and its passage to man through the marine food chain are discussed in Section 3.?

\subsection{GEOLOGY AND TOPOGRAPHY OF THE OCEAN FLOOR}

Relief maps of the North Atlantic and North Pacific ocean floors are presented in Figures 3.1 and 3.2. The oceans are observed to be generally characterized by two depth zones. A relatively shallow shelf surrounds each of the continents. This continental shelf ranges in depth from tidal zones to about 1600 meters, with an average of about 200 meters. Underwater alluvial plains mark the mouths of rivers and there are few significant topographical features.

The continental shelves generally do not extend more than 100 miles beyond coastal ports. The edges of the continental shelf generally fall steeply to depths much greater than 1000 meters. Most of the ocean floor is therefore very deep, averaging 4500 meters. It is marked by mountain ranges and deep trenches but the majority of the deep ocean floor is typified by featureless abyssal plains and rolling abyssal hills.

The physical properties of the ocean floor on the continental shelf may vary widely. Some portions are rocky while areas such as alluvial plains can have unconsolidated sediments over a hundred meters thick. A typical description might be a semirocky plain with unconsolidated sediments on the order of a meter in depth. The deep ocean's floor is less explored than the continental shelf. However, the deep ocean floor can be generally described as having a thick layer of sediments overlying bedrock. The thickness of these sediments is thought to be in the range of hundreds of meters. 


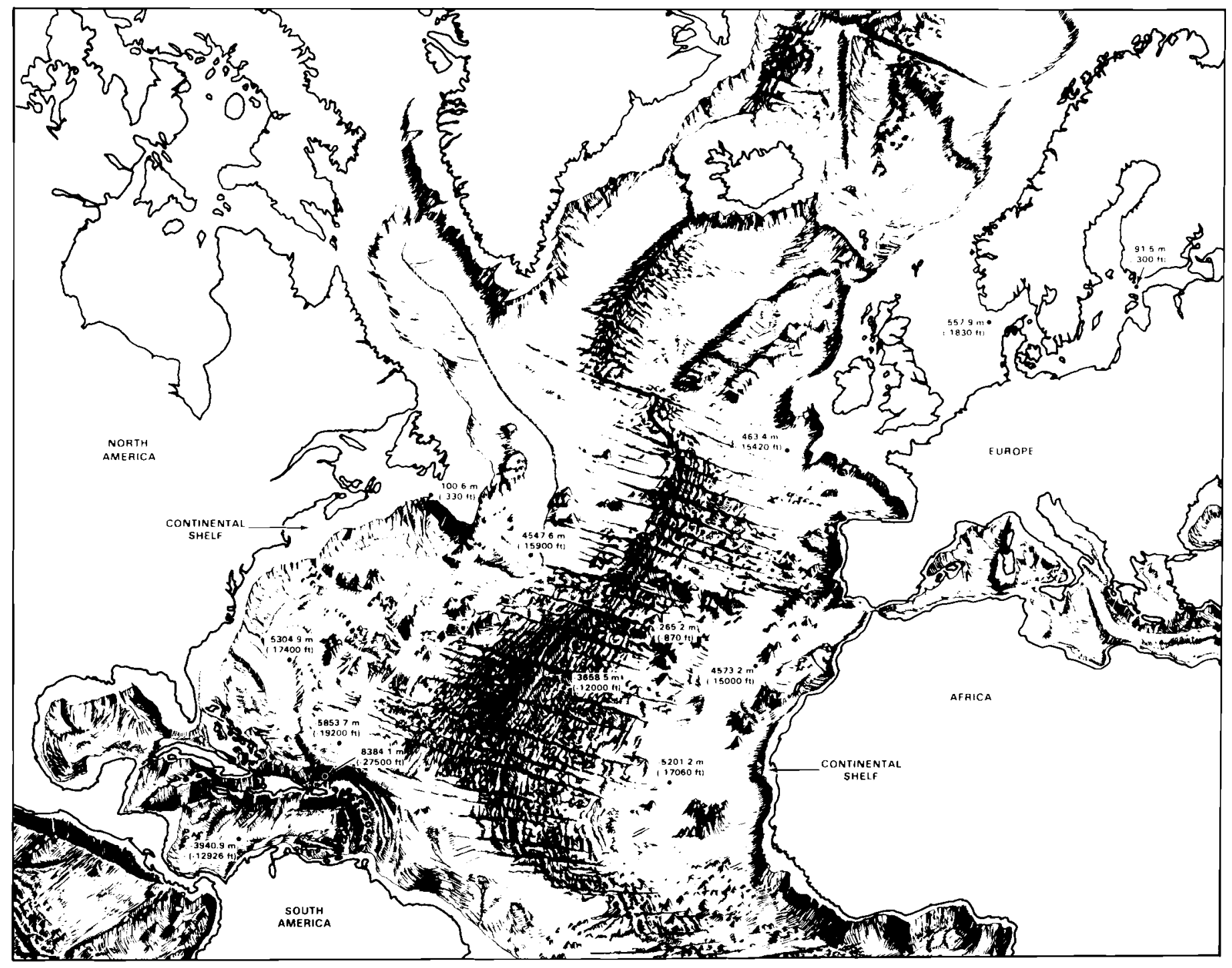

FIGURE 3.1. Relief Map of the North Atlantic Ocean Floor 


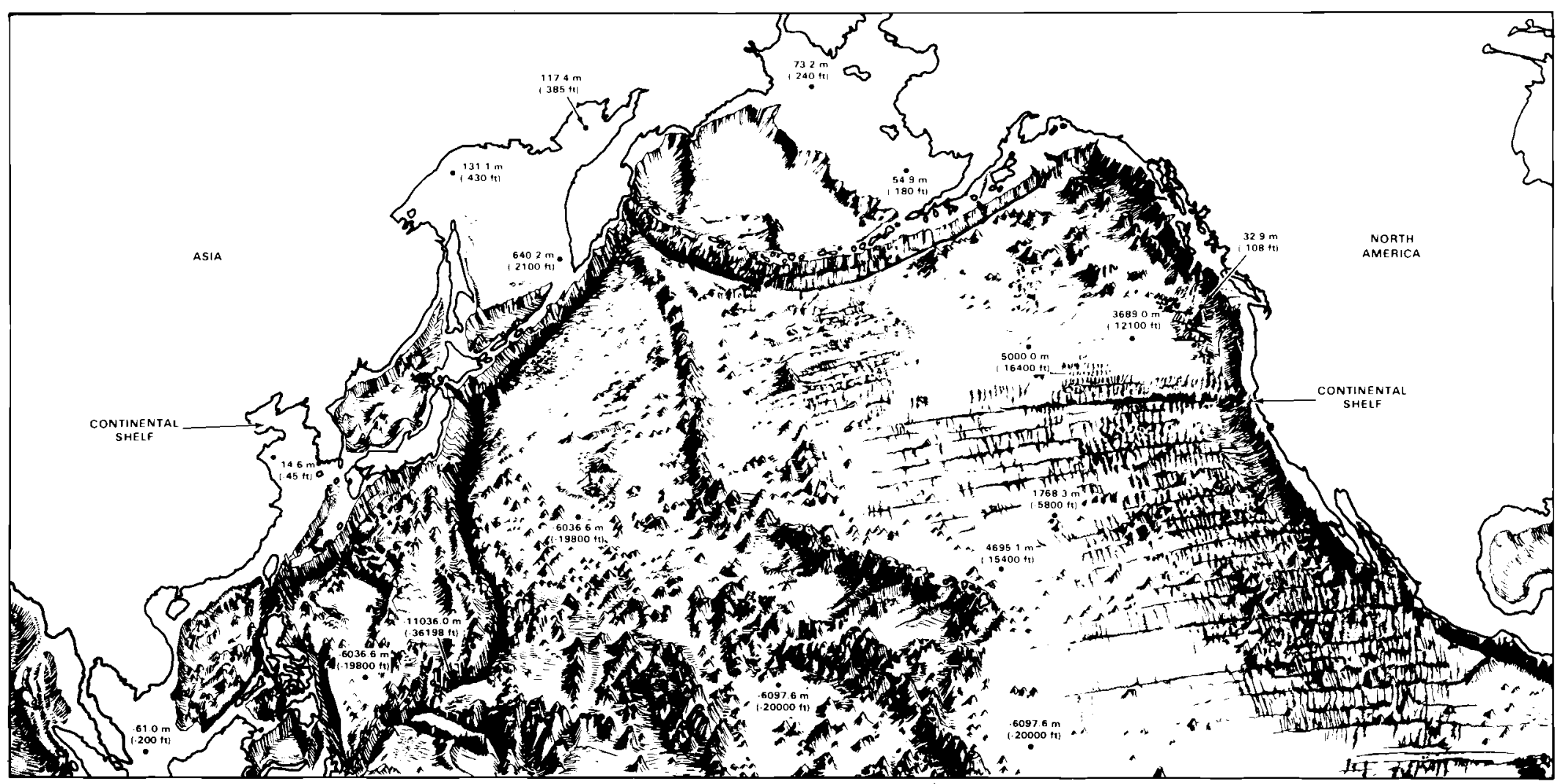

FIGURE 3.2. Relief Map of the North Pacific Ocean Floor 
A profile of water depths encountered along typical intercontinental shipping lanes, such as between the East Coast of the United States and Europe or between the West Coast and Japan is presented in Table 3.1.

TABLE 3.1. Typical Ocean Depths

Along Shipping Lanes

$\begin{array}{lr}\text { Continental Shelf }(<200 \text { meters }) & 5-10 \% \\ 200-3600 \text { meters } & 10-15 \% \\ >3600 \text { meters } & 79-95 \%\end{array}$

For this study, the ocean has been divided into two regions. The first region is the continental shelf, assumed to have a depth of 200 meters. The remainder of the sea is considered to be deep ocean, with a depth in excess of 3600 meters.

\subsection{PROPERTIES OF THE OCEAN ENVIRONMENT THAT COULD CONTRIBUTE TO PACKAGE FAILURE}

Two major mechanisms for inducing failure in a shipping package lost at sea are considered in this study. These mechanisms are hydrostatic pressure and corrosion. Hydrostatic pressure is directly proportional to ocean depth. Pressures range from one atmosphere at the surface to more than 1000 atmospheres in deep ocean trenches. Hydrostatic pressure as a function of depth is shown in Figure 3.3.

Complicated physical processes are involved in corrosion of metals in the marine environment. Corrosion rates have been determined for some metals under particular conditions, but in general these rates may vary with depth, temperature and other properties that depend on the location of the lost package in the ocean. Corrosion rates are discussed in more detail in Appendix A. Generally a rate of $0.1 \mathrm{~mm}$ per year is used for structural or stainless steel and $2.5 \times 10^{-4} \mathrm{~mm}$ per year for zirconium alloys. 


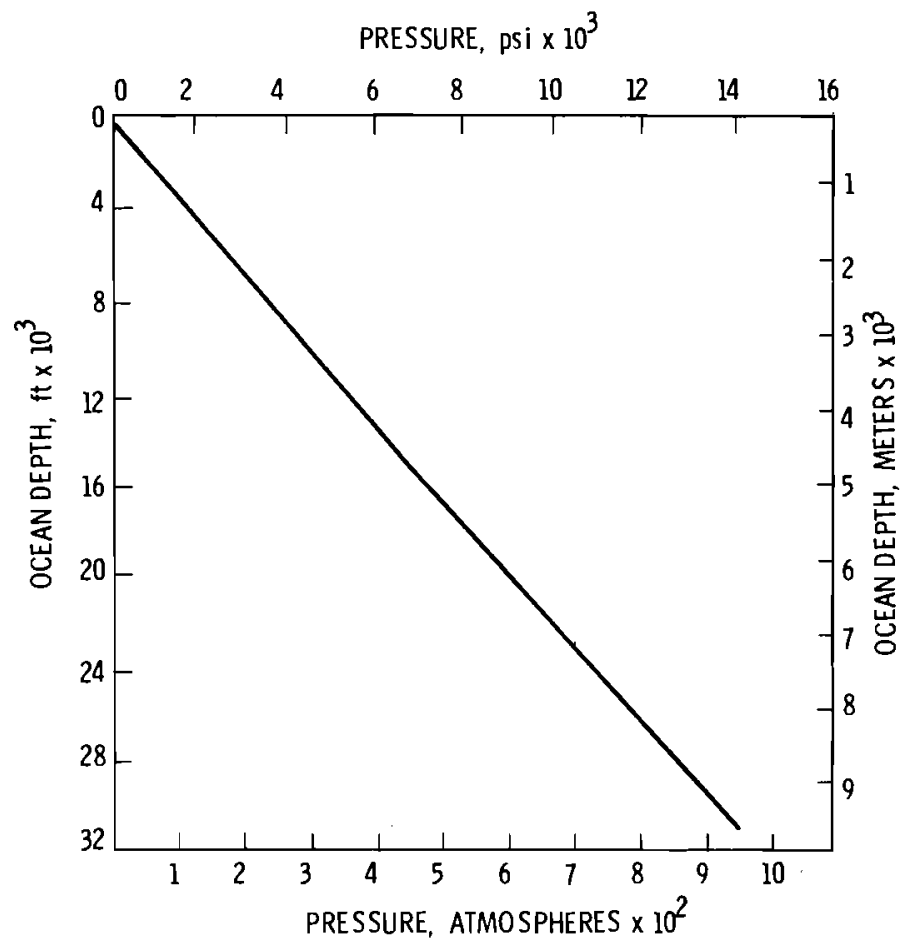

FIGURE 3.3. Hydrostatic Pressure Versus Ocean Depth

\subsection{BEHAVIOR OF RADIOACTIVE MATERIAL IN THE OCEAN}

Radionuclides released into the ocean tend to be dispersed rapidly by the natural mixing of ocean waters. However, biological mechanisms exist in the marine food chain for concentrating some radioactive substances. The primary potential hazard to man following the release of radioactive material into the ocean is through consumption of seafood contaminated with radioactivity. The methodology for estimating the population dose following release of radioactive material in the ocean is discussed in this section. Details of the dose calculation techniques are presented in Appendix $D$.

The population dose from consumption of contaminated seafood was estimated using the following general relationship.

$$
D=U_{p} \sum_{i} C_{i} B_{i}(D F)_{i}
$$


Where the summation is over all radioactive species released and $C_{i}$ is the concentration of a particular radionuclide in the seawater, $B_{i}$ is the biological concentration factor of that nuclide in marine organisms, $U_{p}$ is the average annual consumption of contaminated seafood by the total population and $(D F)_{i}$ is a factor that relates dose to the amount of a radionuclide ingested.

It has been found (see Appendix D) that Equation 3.1 can be expressed in the following way:

$$
D=\frac{P}{2} \sum_{i} Q_{i} B_{i}(D F)_{i}
$$

Where $P$ is the productivity of the contaminated region and $Q_{j}$ is the amount of a particular radionuclide released. Expressed in this way, the dose is independent of the concentration of the radionuclide in seawater. This significantly reduces the complexity of the dose calculations.

The biological concentration factors and dose conversion factors used in this analysis are presented in Appendix D. Seafood production of the oceans of the world varies considerably from region to region depending on the primary production of organic matter. Areas over continental shelves and those where the upwelling of nutrients takes place are regions where the primary production is great and fish and other organisms harvested by man for food are relatively abundant. Seafood production from a typical area of the continental shelf has been estimated to be about $1 \times 10^{-4} \mathrm{~kg} / \mathrm{m}^{3} \mathrm{yr}$. (1) The harvest is assumed to be composed of either $100 \%$ fish or a mixture of seafood consisting of $50 \%$ fish, $25 \%$ crustacea and $25 \%$ molluscs. The edible quantity of seafood available was assumed to be $50 \%$ of the live weight of the harvest.

Areas such as the open ocean are generally much lower in productivity and hence in harvestable fish than the continental shelf. Although some fisheries do extend to the open ocean from the coastal water, it has been estimated that the productivity of these regions is about one thousand times less than the productive areas of the continental shelf. (1) The seafood and fish harvest from these areas is assumed to be $10^{-7} \mathrm{~kg} / \mathrm{m}^{3} \mathrm{yr}$. 
The average dose to a member of the population consuming the seafood harvested from the contaminated region may be estimated if the extent of the contaminated area and the average individual consumption rate of the population are known. For this estimate, the continental shelf region is taken to be a typical coastal fishery extending out $48 \mathrm{~km}$ with a length of $96 \mathrm{~km}$. A 30-meter average depth is assumed for the zone in which seafood is harvested. This results in a fishery with a volume of $1.4 \times 10^{11} \mathrm{~m}^{3}$ yielding $1.4 \times 10^{7} \mathrm{~kg}$ of seafood per year. Using the average U.S. seafood consumption rate of $8 \mathrm{~kg} /$ year and assuming that only 50\% (by weight) of the harvested seafood is edible, approximately 870,000 people consume seafood from this region.

A11 dose estimates made in this study assume that seafood from the contaminated area is consumed for one year and that noncontaminated food is consumed thereafter. Two doses have been calculated. The first is the dose that occurs during the year in which the contaminated seafood is consumed. The 50-year dose commitment resulting from reterition of ingested radionuclides in the body is also calculated. All dose calculations conservatively assume that fishing in the contaminated area is not restricted. It was beyond the scope of this preliminary study to determine the distribution of the dose within the affected population. 
. 


\subsection{SHIPPING PACKAGES AND POSTULATED LOSS SCENARIOS}

In order to simplify the analysis of package failure mechanisms, a specific plutonium shipping package and a generic spent fuel cask design was used in this study. The reference packages are described in this section and the postulated loss scenarios are presented.

\subsection{PLUTONIUM SHIPPING PACKAGE DESCRIPTION}

Plutonium is expected to be shipped in the form of plutonium dioxide. One common package for the shipment of plutonium dioxide is a DOT specification 6M container (see Figure 4.1). There are several different sizes of $6 \mathrm{Ms}$, but this analysis is confined to the $57-\ell$ package. The outer container is typically a $57-\ell$ DOT specification 17c drum. The inner container is steel pipe with an inner diameter of $12.23 \mathrm{~cm}$ and a $0.95 \mathrm{~cm}$ wall thickness (5-in. Sch. 80) closed with a threaded plug. A luting/sealant compound is commonly applied to these threads. The dioxide powder is contained in two sealed No. 8 steel cans which are placed inside the inner container. The inner container is lined with padding to minimize damage to the steel cans during shipment. The inner container is insulated by Celotex Industrial Board with a minimum thickness of $7.6 \mathrm{~cm}$ ( 3 in.). No shielding is provided but may be

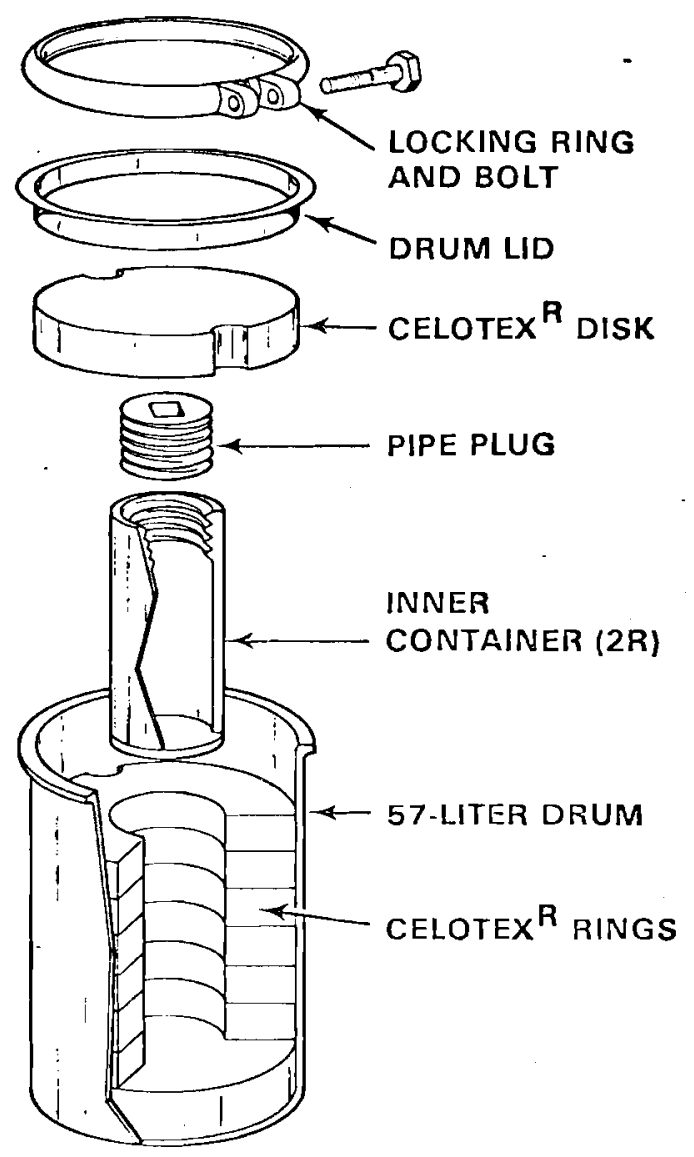
added with the containment vessel when required.

FIGURE 4.1. 6M Container 
The gross weight of a typical loaded 57- $\ell$ 6M package is estimated to be approximately $48 \mathrm{~kg}$. This weight assumes dry insulating material and does not include extra weight that would accompany water logging of the material. If the drum were to leak, the Celotex material is expected to absorb water readily. The $57-\ell$ container will displace $59 \mathrm{~kg}$ of seawater. Packages with dry Celotex insulation will float. If the drum leaks, the water logged Celotex would yield a negatively buoyant package and the $6 \mathrm{M}$ would sink. Packages with added shielding would sink. These observations assume a free package in the sea. Even buoyant packages can be submerged if trapped in a sinking vessel. To determine package failure modes and plutonium release rates, it will be assumed the package is submerged to the ocean floor.

Loss of containers loaded with either high purity plutonium or recycle plutonium has been considered. Research with plutonium fuels can require high purity ${ }^{239} \mathrm{Pu}$. Plutonium recovered from light water reactors has a lower ${ }^{239} \mathrm{Pu}$ content but contains more of the higher mass plutonium isotopes. The $6 \mathrm{M}$ package is allowed to contain $4.5 \mathrm{~kg}$ of $\mathrm{PuO}_{2}$ in the high purity form. Only $2.55 \mathrm{~kg}$ of recycle plutonium is permitted due to the heat generation of the higher mass plutonium isotopes. Section C.l of Appendix $C$ gives the plutonium isotopic mixtures used.

\subsection{SPENT FUEL SHIPPING PACKAGE DESCRIPTION}

Designs have been developed for spent fuel casks with capacities ranging from 1 PWR (or 2 BWR) fuel elements to 12 PWR (or 32 BWR) elements. It is anticipated that economic considerations would favor the use of larger casks with a larger payload to total weight ratio, for sea transport of spent fuel. A large spent fuel cask of the type currently being used to ship spent fuel by rail has been selected as the reference cask for this study.

The reference cask, shown in Figure 4.2 , is a water-cooled cylindrical cask designed to carry 3.1 MT of spent fuel. It has a gross weight of 73 MT. Shielding is provided by water filling the cask cavity, $10 \mathrm{~cm}$ of lead in the cask shell and an exterior water-filled enclosure. Heat is removed from the fuel to the cask cavity walls by natural circulation of the 


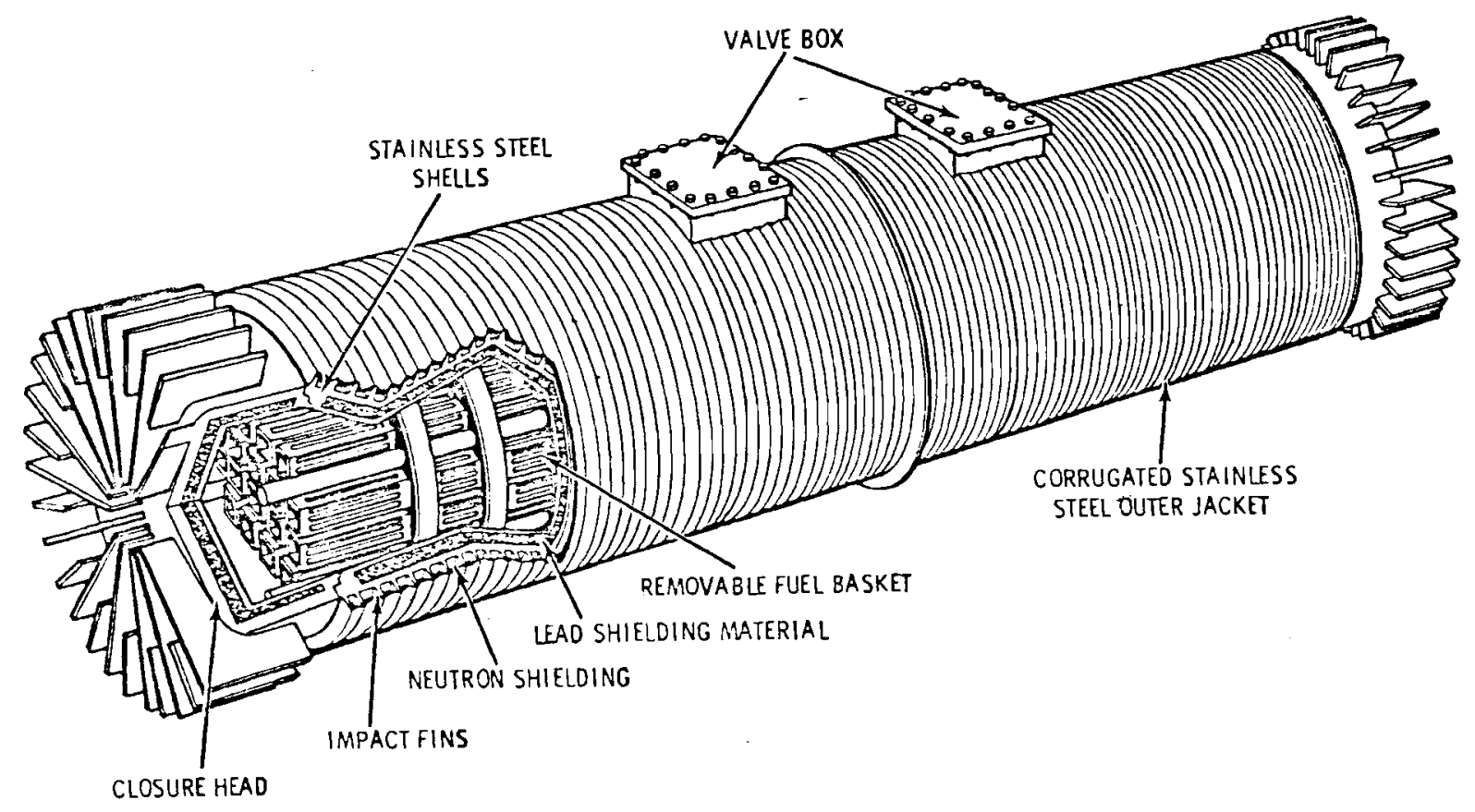

FIGURE 4.2. Spent Fuel Cask

contained water and transmitted through the cask sides and ends by conduction. The outer structure shell of the cask is 3 to $5 \mathrm{~cm}$ thick stainless steel. The inner shell is also stainless steel. The outer shell is surrounded by an annulus of water retained by a corrugated jacket. The corrugated jacket is cooled by two diesel-driven blowers. The cask is designed to be able to remove the decay heat by natural convection if the diesel blowers are damaged in an accident.

The inner cavity of the cask contains removable fuel baskets that facilitate removal and insertion of the fuel bundles and support the bundles during shipment. The cask 1 id is bolted and sealed in place during shipment. One possible design of the reference cask is assumed to have a rupture disc to relieve excess pressure that might build up in the cask cavity. other cask designs use relief valves for this purpose. Since relief valves may make the cask more resistant to failure in the ocean, both cases have been considered in the analysis. 
For this analysis, the cask was assumed to carry 3.1 MTU of PWR fuel with an average exposure of 33,000 MWd/MTU at an initial enrichment of $3.3 \%{ }^{235} U$.

\subsection{POSTULATED LOSS SCENARIOS}

Three items are required to define a loss event. These are, package type, pre-loss damage and location of loss. The two radioactive material packages considered are the plutonium 6M package and the large spent fuel cask. The location of loss is divided into the continental shelf waters (200-m depth) and the deep ocean. The condition of the package prior to loss can greatly affect the release and consequent dose resulting from the loss. For this study, two specific pre-loss conditions were considered. The first is an undamaged package assumed to have its full design integrity. The second is that of a package damaged by a shipboard fire. The fire environment associated with commercial freighters is not well defined. Fires can last from a few minutes to a few days in extreme cases. Perhaps the most extreme case is when a cargo vessel collides with a bulk liquid carrier transporting millions of gallons of highly flammable fuel and both vessels stay together and burn on the surface. A study performed by Sandia Laboratories $(2)$ indicates that the average fire temperature to use for hydrocarbon fires is approximately $1010^{\circ} \mathrm{C}\left(1850^{\circ} \mathrm{F}\right)$. This value will be used throughout this study. Other types of damage (e.g., as might result from two vessels colliding or in a vessel sinking) are not considered.

For this study, it was found that exposure to an extended fire did not appreciably affect the performance of the $6 \mathrm{M}$ container in the ocean environment. Extended exposure to hydrocarbon fires averaging $1010^{\circ} \mathrm{C}\left(1850^{\circ} \mathrm{F}\right)$ is not expected to release the radioactive contents from the container because plutonium dioxide is inert in that temperature range. The inner $2 R$ vesse 1 and cans holding the product would pressurize to approximately 64 psi upon reaching equilibrium with the fire $\left(1010^{\circ} \mathrm{C}\right)$. It is assumed that the inner cans would be overpressurized and rupture before reaching this pressure. The $2 R$ vessel would not rupture. Instead the pressure is expected to slowly relieve past the seal and threads. Leakage of gas from the $2 R$ would not be 
expected to convey the solid plutonium dioxide past the threads. A fire could result in some damage to the sealant and threads, however, this is not considered important for the accident scenarios in this report.

For the spent fuel cask, in addition to the undamaged case, three degrees of fire damage are considered. These are minor, moderate and severe fires. Since a detailed thermal analysis of a spent fuel cask under accident conditions was beyond the scope of this study, no attempt has been made to relate the level of fire damage to the intensity and duration of fire required to produce this damage. The severity of a fire is defined only by the damage it produces. A minor fire is defined as a fire which does not damage the cask. A moderate fire is one that activates the pressure relief devices on the cask. In a severe fire, it is assumed that the relief devices will open, the cooling water will vent and eventual1y the fuel rods will burst. The fire duration is assumed to be sufficient to fail all the fuel rods and drive most of the volatile fission products from the fuel, exposing them to seawater upon immersion. Fires of this duration and intensity are considered to have a very low probability of occurrence and represent a fire condition that would probably not be included in studies of the safety of transporting spent fuel by truck or rail. This case has been considered in this analysis since it is believed to represent the maximum possible pre-loss damage that could occur, and should place an upper bound on the consequences of the loss of a spent fuel cask in the ocean for the loss scenarios considered in this study.

Table 4.1 combines these pre-loss damage conditions with the other two items, defining the loss event to show the loss scenarios that are considered in this study. 
TABLE 4.1 Loss Scenarios

Containment Barriers

Package Type

Location of Loss Pre-loss Damage

Breached Prior to Loss

$6 \mathrm{M}$

Continental Shelf Undamaged

None

$6 \mathrm{M}$

Deep Ocean

Undamaged

None

$6 \mathrm{M}$

Continental Shelf

Fire Damage

None

$6 \mathrm{M}$

Deep Ocean

Fire Damage

None

Spent Fuel Cask Continental Shelf Undamaged None

Spent Fuel Cask Deep Ocean Undamaged None

Spent Fuel Cask Continental Shelf Minor Fire None

Spent Fuel Cask Deep Ocean Minor Fire None

Spent Fuel Cask Continental Shelf Moderate Fire Cask

Spent Fuel Cask Deep Ocean Moderate Fire Cask

Spent Fuel Cask Continental Shelf Severe Fire Cask, Fuel Rods

Spent Fuel Cask Deep Ocean Severe Fire Cask, Fuel Rods 


\subsection{CONSEQUENCES OF POSTULATED LOSS SCENARIOS - PLUTONIUM SHIPPING PACKAGE}

Plutonium package loss scenarios considered in this study were presented in Section 4.3. This section discusses the failure mechanisms for 6M packages in the ocean environment, presents an estimate of the material release rates from the failed package and estimates the radiological impact of the four loss scenarios considered.

\subsection{PACKAGE FAILURE IN THE SEA}

As the package is exposed to the forces of corrosion and hydrostatic pressure, its containment integrity is breached at some level of insult. This level is referred to as the failure threshold of the package. Failure is defined here as loss of containment. The failure thresholds of the packages in the sea are summarized in this section. A more complete analysis of the thresholds is given in Appendix A.

Once thresholds for failure have been established, each loss scenario is examined to determine the most likely mode of failure. This most likely mode is called the critiçal failure mode.

\subsubsection{Plutonium Package Failure Thesholds}

It is calculated that submersion to a depth of approximately 3000 meters $(9840 \mathrm{ft}$ ) would be required to collapse the inner 2R container of the $6 \mathrm{M}$ package. However, it is possible that the $2 R$ could permit limited entry of sea water past the pipe plug threads at pressures encountered on the continental shelf. Both the outer drum and the inner cans are expected to fail at low differential pressures. Thus, sea water could penetrate the vessel and mix with the plutonium dioxide at depths characteristic of the continental shelf. The rate of interchange between the inside of the package and the sea past the threads was not calculated, but is felt to be extremely slow.

In descents to depths greater than the continental shelf, inleakage is expected to equalize pressures, preventing the collapse of the $2 R$ container. Therefore, descents to depths greater than the continental shelf will not result in more severe failures. 
Sea water is expected to enter the outer drum even at shallow depths. This exposes the inner $2 \mathrm{R}$ steel vessel to corrosion. Failure by corrosion of the $2 \mathrm{R}$ vessel is estimated to take 125 years. However, the primary mode of failure for the 6M package is assumed to be pressure-induced leakage. While corrosion will eventually destroy the package, it is expected that the package's containment integrity will be compromised by inleakage in much shorter times.

\section{1 .2 Critical Failure Modes}

As discussed previously, there are several possible ways to fail the shipping package. For each loss event, there is then a single most likely or critical failure mode. Table 5.1 relates each of the original four plutonium package loss scenarios with its critical failure mode. The failure mode of the 6M package is the same for all four loss events considered. This means that although a package may be subjected to different forces in different loss events, it fails the same way. Also included in the table is an indication of the time between the loss and the containment failure. It is important to separate the concepts of failure and release. The failure is the breach of the package containment, while release refers to the passage of the radioactive material through that breach. While the release will begin at the time of failure, it may be a rather slow process. The time spans associated with releases are discussed further in the next section.

\section{TABLE 5.1. Critical Failure Modes of Plutonium Package by Loss Scenario}

\section{Pre-loss Condition \\ Fire Damage \\ Fire Damage Undamaged Undamaged}

\begin{tabular}{l}
$\begin{array}{c}\text { Depth } \\
\text { of Ocean }\end{array}$ \\
\hline Cont. Shelf \\
Deep Ocean \\
Cont. Shelf \\
Deep Ocean
\end{tabular}$$
\text { Lea }
$$$$
\begin{aligned}
& \text { Critical Failure Mode } \\
& \text { Leakage past plug, inner can collapse. } \\
& \text { Leakage past plug, inner can collapse. } \\
& \text { Leakage past plug, inner can collapse. } \\
& \text { Leakage past plug, inner can collapse. }
\end{aligned}
$$

Critical Failure Mode

(1) Note this is time to failure, not time required for release.
Time Between Loss and Failure (a)

Immediate Immediate Immedia te Immedia te 


\subsection{PLUTONIUM RELEASE FROM 6M PACKAGE}

The release of plutonium from the $6 \mathrm{M}$ package is difficult to estimate. It was assumed that sea water will leak past the threads of the $2 R$ container and fail the inner can even at shallow depths. With these containment failures, sea water is mixing with the plutonium dioxide powder. The wet powder in the $2 R$ container must pass through several barriers to reach the marine environment.

As nominal sized particles of oxide, plutonium will not tend to concentrate in the marine food chain. This is because ingested $\mathrm{PuO}_{2}$ will pass through the organism with little retention. The first barrier is then the dissolution of the oxide. The dissolution of $\mathrm{PuO}_{2}$ in sea water has been the subject of much study. Given a large enough volume of water it can be postulated that all the $\mathrm{PuO}_{2}$ within the $6 \mathrm{M}$ package would dissolve within one year ${ }^{(3)}$. However, there are indications that the limiting solubility of $\mathrm{Pu}$ in sea water is in the sub-mg/l range ${ }^{(4)}$. For a package with limited exchange with the sea, this represents a second barrier in that it would be difficult to expose the $\mathrm{PuO}_{2}$ to a sufficient volume of water to achieve complete dissolution. The transport of plutonium from the $6 \mathrm{M}$ into the sea is limited then by $\mathrm{PuO}_{2}$ solubility, water exchange from the $2 \mathrm{R}$ to the sea and/or chemical diffusion of the $\mathrm{PuO}_{2}$ dissolution products from the $2 R$.

To determine the effectiveness of these barriers to plutonium releases, specific knowledge is required about the leak path from the $2 R$, the surrounding environmental conditions and other parameters. These items would be dependent on pre-loss condition, deformation to threads during descent, location of loss, orientation of the package and a host of other variables. Because of these unknown factors, it was not possible to determine quantitatively the release rate from the $6 \mathrm{M}$ package. Lacking this information, it was assumed all of the plutonium in the package was released in a soluble form within the first year for all loss scenarios. The amount of plutonium assumed to be released is given in Table C.1. It is felt this is an over estimation but uncertainties preclude a better estimate. 


\subsection{RADIOLOGICAL IMPACT}

The estimated radiological impact from the postulated release of plutonium from a $6 \mathrm{M}$ shipping package is presented in this section. The impact described is based on the description of the ocean environment discussed in Section 3.3 and on the release amount and rate given in the preceding section. The impact on both man and the marine biota is considered.

In estimating the impact on man, calculations were performed which model the transport of radionuclides through the marine food chain to man. Calculations were made for releases of both low burnup and typical recycle plutonium. Dose calculations were made for harvest of fish only and a mixture of fish and shellfish. The results of these calculations for the two loss scenarios (loss to the continental shelf and loss to the deep ocean) are shown in Table 5.2. Dose and dose commitments are given for the total populations and an average U.S. seafood consuming individual. The dose values are that amount of radiation received from one year's intake during that same year. If no more contaminated seafood is consumed, irradiation of the exposed population from radioisotopes retained in their bodies will continue. The dose commitment is a measure of this irradiation. It assumes one year of intake and a 50-year period for continued irradiation from retained material.

For the low burnup plutonium cases, the dose results mainly from ${ }^{239} \mathrm{Pu}$. The majority of the dose for the recycle cases comes from the ${ }^{241} \mathrm{Pu}$ and ${ }^{241} \mathrm{Am}$. Table 5.2 shows a difference of a factor of 1000 between the continental shelf and deep ocean values. This is a direct scaling from the difference in marine productivity between these two regions. Since the failure modes are the same for both loss scenarios, only the productivity is responsible for the difference in the impact.

The doses from the plutonium package loss scenarios are fairly small, particularly when compared to the average individual's natural background radiation dose of approximately 0.12 rem per year. 
TABLE 5.2. Estimated Dose from Contaminated Seafood Consumption after Loss of a Single Plutonium Package at Sea

Low Burnup $\mathrm{Pu}(\mathrm{a})$
Fish_Seafood $(\mathrm{c})$
Dose

Total

Population:

(man-rem)

Continental

Shelf

$9 \times 10^{-3}$

0.28

$9 \times 10^{-6}$

$2.8 \times 10^{-4}$

0.79

26

Deep Ocean

Average

Individual:

(rem)

Continental

Shelf

$1.0 \times 10^{-8} 3.2 \times 10^{-7} \quad 9.1 \times 10^{-7} \quad 3.0 \times 10^{-5}$

$1.6 \times 10^{-7} 4.3 \times 10^{-6}$

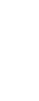

$1.1 \times 10^{-5} 2.7 \times 10^{-4}$

Deep Ocean

Deep Ocean $1.0 \times 10^{-11} 3.2 \times 10^{-10} 9.1 \times 10^{-10} 3.0$

(b) $2.55 \mathrm{~kg} \mathrm{Pu}$ per package with $1.5 \mathrm{wt} \%{ }^{238} \mathrm{Pu}, 58 \mathrm{wt} \%{ }^{239} \mathrm{Pu}, 24$ wt $\%{ }^{240} \mathrm{Pu}, 11 \mathrm{wt} \%{ }^{241} \mathrm{Pu}, 4.9 \mathrm{wt} \%{ }^{242} \mathrm{Pu}, 1.0 \mathrm{wt} \%{ }^{241} \mathrm{Am}$.

(c) Mix of $50 \%$ fish, $25 \%$ crustaceans and $25 \%$ molluscs. 
Insufficient data are available to accurately assess the effects of a plutonium release on the marine biota. A recent review of the available data on the effects of ionizing radiation on aquatic organisms and ecosystems ${ }^{(5)}$ would indicate that acute doses in the order of 100 rad are required to cause mortality to individual organisms; while under chronic exposure, some minor effects could be detected at dose rates in the order of 1 rad/day. Potential effects upon populations of marine biota, rather than individual organisms, are of primary concern. Therefore, dose rates would have to be maintained at the high levels over a large segment of the ocean if they are to affect, for example, mortality, growth, and fecundity rates and ultimately the reproductive success of that biota population.

Under the conditions described, it is unlikely that a release of this kind will have a discernable impact on the ecosystem. Sedentary organisms such as clams and oysters near the point of release may be affected to some extent by the release. An organism such as clam or oyster located approximately one meter "downstream"(a) from the point of an instantaneous release of 200 curies of ${ }^{239} \mathrm{Pu}$ could accumulate a concentration of $4 \times 10^{4} \mathrm{pCi} / \mathrm{g}$ assuming equilibrium is attained within one day. Such a concentration would deliver a dose rate to the mollusc of approximately $10 \mathrm{rad} / \mathrm{d}$. This dose rate probably would not be lethal for these organisms. ${ }^{(5)}$ Organisms such as fish or crabs in the immediate region of the release would not be expected to be irradiated to the same degree since they are mobile and will not necessarily remain in the high concentration area. Even if some of the biota are killed in the immediate area, their loss to the population in terms of reproduction would be insignificant.

(a) At which point the dilution factor would be approximately $25 \mathrm{~s} / \mathrm{m}^{3}$ (SNAP-27 Safety Report. 1968, page B-10). 


\subsection{CONSEQUENCES OF POSTULATED LOSS SCENARIOS - SPENT FUEL SHIPPING PACKAGE}

Eight loss scenarios were given in Section 4.3 for the spent fuel shipping package. This section presents a discussion of package failure mechanisms, estimates material releases and evaluates the radiological impact of those releases.

\subsection{SPENT FUEL PACKAGE FAILURE THRESHOLDS}

After loss to the sea, the package is subjected to the forces of hydrostatic pressure and corrosion. The spent fuel cask has multiple levels of containment that must be considered in the determination of failure thesholds. Details of the failure threshold calculations are given in Appendix $A$.

\subsubsection{Failure Threshold of Spent Fuel Cask by Hydrostatic Pressure}

There are two stages of failure for an intact cask. First is failure of the seals or pressure relief devices, providing a pathway between the fuel rods and the sea. Second is the failure of the fuel rods themselves under external pressure.

The closure of a spent fuel cask includes the closure head seal and pressure relief devices. These are generally designed to withstand an internal pressure of roughly $27 \mathrm{~atm}(400 \mathrm{psi})$. Some pressure relief devices and many types of seals are quite resistant to pressures in the direction opposite to the design differential pressure. However, pressure relief devices such as rupture discs, which act only on differential pressure, are not extremely resistant to failure from external pressurization. It is possible that such a device would activate at an external pressure of $27 \mathrm{~atm}$ (400 psi). This pressure would occur at a depth of $260 \mathrm{~m}(870 \mathrm{ft})$. This implies that at or near the continental shelf $(200 \mathrm{~m})$ leakage into the cask might occur. In shallower waters, it is likely that relief devices would hold and the cask integrity would not be diminished.

It is estimated that if the seal and pressure relief devices did not leak, the cask wal1 would collapse after descending $1670 \mathrm{~m}(5480 \mathrm{ft})$ into the ocean. 
Tests conducted under the Atomic Energy Bureau, Science and Technology Agency, (6) Japan, have indicated that a cask could maintain integrity at an external pressure of $480 \mathrm{~atm}(7100 \mathrm{psi})$. The tests determined the critical pressure for collapse of the cask was between $155 \mathrm{~atm}$ (2280 psi) and $213 \mathrm{~atm}$ (3130 psi). Tests have also been conducted on a pressure equalizing device which would balance internal and external pressures, precluding any pressureinduced failure of the cask. No current casks have such a device.

- Since the cask may or may not leak on the continental shelf, depending on closure design, two continental shelf loss cases will be carried through the analysis. One will assume leakage and the other no leakage. For a11 losses to the deep ocean, leakage into the cask will be assumed.

Once the cask is breached, the fuel rods are exposed to the hydrostatic pressure. The two types of LWRs, pressurized water reactors (PWR) and boiling water reactors (BWR), have somewhat different fuel rods. The BWR rods generally have greater diameters and thicker cladding. Both PWR and BWR fuel rods are sealed hermetically, so failure will occur by collapsing radially inward upon reaching a critical ocean depth. It was assumed that the $\mathrm{UO}_{2}$ fuel pellets are packed tightly in the clad; therefore, the rod would likely fail at the gas-filled plenum at the end of the rod. For the PWR rods, it was calculated that $270 \mathrm{~atm}(4000 \mathrm{psi})$ would be required to cause collapse. This is equivalent to a depth of $2700 \mathrm{~m}(8900 \mathrm{ft})$. The BWR rods were calculated to fail at $310 \mathrm{~atm}(4600 \mathrm{psi})$ or $3100 \mathrm{~m}(10,300 \mathrm{ft})$ depth. Thus, neither the PWR nor

- BWR rods will collapse on the continental shelf but both will fail in the deep ocean.

\subsubsection{Failure Threshold of Spent Fuel Cask by Corrosion}

The wall of the cask presents at least $5 \mathrm{~cm}$ stainless steel as a barrier to corrosion. The mechanisms of corrosion in stainless steel exposed to sea water are very complex. An estimated corrosion rate of $0.1 \mathrm{~mm}(3 \mathrm{mils})$ per year indicates an intact cask would provide some barrier to sea water for at least 500 years.

Initially the interchange of sea water between the interior of the cask and the ocean will be limited to no more than small openings past leaking 
seals or pressure relief devices. This will limit the exposure of the fuel rods to the seawater. Concurrent corrosion attack on the outer stainless steel shell and shielding would tend to expose the entire cask contents more directly to the marine environment after a long period of time.

Corrosion of the Zircaloy fuel clad in the marine environment is difficult to predict because of an almost complete lack of test data. Zirconium and Zircaloys are exceptionally stable in sea water, exhibiting a corrosion resistance similar to titanium, but the resistance to corrosion can be affected significantly by impurities. (7)

The corrosion rates can be estimated from the rates found for titanium alloys by a U.S. Naval Civil Engineering Laboratory ${ }^{(8)}$ test. The NCEL found essentially no visible corrosion on specimens of alloys, which would indicate a rate less than $2.5 \times 10^{-5} \mathrm{~mm}$ per year. Certain isolated areas of unusually rapid corrosion, such as welds, have been observed to corrode at rates of approximately $2.5 \times 10^{-4} \mathrm{~mm}$ per year. Thus, it is possible that corrosion could open very 1 imited weld areas within 2000 years. Other corrosion mechanisms could cause localized failures in less time. General wasting away of the material would not be expected for tens of thousands of years.

In cases where the fuel rods are not failed by extended fire and the cask does not descend to great depths, corrosion is the primary failure mechanism. Massive failure of the fuel rods by this means is expected to take tens of thousands of years.

\subsubsection{Critical Failure Modes}

With the failure thresholds given above, each loss scenario can be examined for its critical, or first to occur, failure mode. Table 6.1 relates each scenario with its critical failure mode. Additional cases to allow for the possible failure or non-failure of the cask at continental shelf depths. It can be seen that many of the failure modes are repeated. The undamaged, minor fire and moderate fire cases for a package lost to the deep ocean are all similiar. In the moderate fire case, the fire causes the failure of the cask containment but if lost to deep water, the cask would be expected to fail anyway. For those cases in which the cask is assumed 
continental shelf depths, all nonsevere fire cases also have a similar failure mode. In the undamaged and minor fire cases where the cask is assumed to be resistant to continental shelf pressures, corrosion of both cask and fuel rods is the common failure mode. The moderate fire case for a pressure resistant cask poses a problem of classification. The moderate fire is defined as activating pressure relief devices. However, many of the devices would reseal after a modest release. Rather than attempt to quantify this partial release, this case will be grouped with those assuming failure of the cask containment on the continental shelf. In the severe fire case, no distinction need be made between continental shelf and deep ocean failure modes, as the fire is assumed to fail the rods before loss.

\section{TABLE 6.1. Critical Failure Mode of Spent Fuel Package by Loss Scenario}

\begin{tabular}{|c|c|c|}
\hline $\begin{array}{l}\text { Pre-loss } \\
\text { Condition }\end{array}$ & $\begin{array}{l}\text { Depth } \\
\text { of Ocean }\end{array}$ & Critical Failure Mode \\
\hline Severe Fire & Cont. Shelf & $\begin{array}{l}\text { Fire induced failure of cask pressure } \\
\text { relief devices and fuel rod failure. }\end{array}$ \\
\hline Severe Fire & Deep Ocean & $\begin{array}{l}\text { Fire induced failure of cask pressure } \\
\text { relief devices and fuel rod failure. }\end{array}$ \\
\hline Moderate Fire & Cont. Shelf & $\begin{array}{l}\text { Fire induced failure of cask pressure } \\
\text { relief devices, corrosion failure of } \\
\text { fuel rods. }\end{array}$ \\
\hline Moderate Fire & Deep Ocean & $\begin{array}{l}\text { Fire induced failure of cask pressure } \\
\text { relief devices, hydrostatic pressure } \\
\text { induced failure of fuel rods. }\end{array}$ \\
\hline \multirow[t]{3}{*}{ Minor Fire } & Cont. Shelf & $\begin{array}{l}\text { Hydrostatic pressure induced failure } \\
\text { of cask seals, corrosion failure of } \\
\text { fuel rods }\end{array}$ \\
\hline & & or \\
\hline & & $\begin{array}{l}\text { corrosion failure of cask, corrosion } \\
\text { failure of fuel rods. }\end{array}$ \\
\hline Minor Fire & Deep Ocean & $\begin{array}{l}\text { Hydrostatic pressure induced failure } \\
\text { of cask seals, and fuel rods. }\end{array}$ \\
\hline \multirow[t]{3}{*}{ Undamaged } & Cont. Shelf & $\begin{array}{l}\text { Hydrostatic pressure induced failure } \\
\text { of cask seals, corrosion failure of } \\
\text { fuel rods }\end{array}$ \\
\hline & & or \\
\hline & & $\begin{array}{l}\text { corrosion failure of cask, corrosion } \\
\text { failure of fuel rods. }\end{array}$ \\
\hline Undamaged & Deep Ocean & $\begin{array}{l}\text { Hydrostatic pressure induced failure } \\
\text { of cask seals and fuel rods. }\end{array}$ \\
\hline
\end{tabular}


Table 6.2 reduces the original eight loss scenarios into five with different failure modes or loss locations. Also included in the table is an indication of the time between the loss and the containment failure. It is important to separate the concepts of failure and release. The failure is the breach of the package containment, while release refers to the passage of the radioactive material through that breach. While the release will begin at the time of failure, it may be a rather slow process. The time spans associated with releases are discussed further in the next section.

\section{TABLE 6.2. Unique Critical Failure Modes - Spent Fuel Package}

\begin{tabular}{|c|c|c|}
\hline Loss Events with Common Failure Mode & Critical Failure Mode & Time Between Loss and Failure ${ }^{(a)}$ \\
\hline $\begin{array}{l}\text { Severe Fire, Cask Lost to } \\
\text { Cont. Shelf }\end{array}$ & $\begin{array}{l}\text { Fire induced failure } \\
\text { of cask pressure } \\
\text { relief devices and } \\
\text { fuel rods }\end{array}$ & Immediate \\
\hline Severe Fire, Cask Lost to Deep Ocean & $\begin{array}{l}\text { Fire induced failure } \\
\text { of cask pressure } \\
\text { relief devices and } \\
\text { fuel rods }\end{array}$ & Immediate \\
\hline $\begin{array}{l}\text { Nonsevere Fire, Cask Lost to } \\
\text { Cont. Shelf - Cask not resistant } \\
\text { to pressure }\end{array}$ & $\begin{array}{l}\text { Hydrostatic pressure } \\
\text { induced cask failure, } \\
\text { fuel rod failure by } \\
\text { corrosion }\end{array}$ & $\begin{array}{l}\sim 1,000-10,000 \text { years for fuel } \\
\text { rod failure (cask barrier fail- } \\
\text { ure - immediate) }\end{array}$ \\
\hline $\begin{array}{l}\text { Nonsevere Fire, Cask Lost to } \\
\text { Cont. Shelf - Cask resistant to } \\
\text { pressure }\end{array}$ & $\begin{array}{l}\text { Corrosion failure of } \\
\text { cask, corrosion fail- } \\
\text { ure of fuel rods }\end{array}$ & $\begin{array}{l}\text { } 500 \text { yr for cask failure, } 1,000- \\
10,000 \text { years for fuel rod } \\
\text { failure }\end{array}$ \\
\hline $\begin{array}{l}\text { Nonsevere Fire, Cask Lost to Deep } \\
\text { Ocean }\end{array}$ & $\begin{array}{l}\text { Hydrostatic pressure } \\
\text { induced failure of } \\
\text { cask seals and fuel } \\
\text { rods }\end{array}$ & Immed ia te \\
\hline
\end{tabular}

\subsection{RADIOACTIVE MATERIAL RELEASES FROM SPENT FUEL PACKAGE}

The magnitude of the consequences of a spent fuel package failure in the ocean will depend on the amount and duration of the radioactive releases which in turn are dependent on the mode of package failure. The release rates and quantities which correspond to specific failure modes are discussed in this section. In some cases a lack of data or other limitations have made it 
necessary to make conservative assumptions in calculating the releases. In those cases the release information presented is believed to place an upper bound on the amount of material released.

The computer code ORIGIN ${ }^{(9)}$ was used to estimate the quantity of the radioactive isotopes present within the fuel at various times following the accident. The fuel was assumed to have been discharged from the reactor 150 days prior to the accident. The cask is further assumed to contain 3.1 MT of uranium irradiated to 33,000 MWd/MTM burnup. The radioactive isotopes and release amounts are shown in Appendix C.

The release of radioactive fission products from $\mathrm{UO}_{2}$ fuel rods in the event of a shipping cask accident at sea has been examined for the two time-tofailure modes:

1. An immediate failure of the rods resulting in immediate release of the semi-volatile fission products and exposure of the fuel to the sea environment.

2. The 1000-year delayed rod failure and release as a result of corrosion failure of the fuel rods.

An additional time consideration is the time before the cask is breached. The contaminated cooling water and fraction of pre-shipment failed fuel account for another release source. Again two times are considered, immediate and delayed. These will be treated as subsets of the time to rod failure cases.

\subsubsection{Immediate Rod Failure}

As shown in Table 6.2, immediate fuel rod failure will result from either a severe fire or by hydrostatic pressure from cask loss in the deep ocean. Fission product releases resulting from immediate rod failure have been separated into two release modes:

- thermally activated diffusion from the $\mathrm{UO}_{2}$ matrix, and

- leaching of the $\mathrm{UO}_{2}$ with sea water.

A graphic illustration of these two release modes is shown in Figure 6.1. 
It is likely that much of the volatiles released during a severe fire will plate out on cooler surfaces such as the cask or ship's structure. This has no effect on the release term, however. Since it has

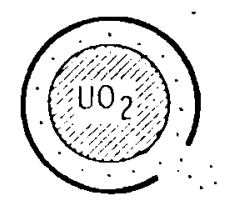

RAPID

Washout of Volatiles in Gap and Plenum

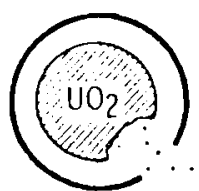

HUNDREDS OF YEARS

Leaching of Fission Products from Ceramic $\mathrm{UO}_{2}$ Fue 1 been assumed that the vessel sinks following the fire, this plated out material will be washed off into

FIGURE 6.1. Release Mechanisms for Fission Products from Failed Spent Fuel Rod in the Ocean the sea.

\subsubsection{Thermally Activated Diffusion}

Thermally activated diffusion is an important release mechanism during in-reactor operation. The relatively high temperatures within a commercial operating fuel rod $\left(400-2000^{\circ} \mathrm{C}\right)$ act as a driving force for fission product diffusion out of the fuel matrix into the rod void volume (i.e., plenum plus the fuel-to-clad gap). (See Figures 6.1 and 6.2.) The fractional releases of the gaseous and semi-volatile fission products during normal commercial reactor operation have been taken from the WASH-1400 report ${ }^{(10)}$ and given in the first part of Table 6.3. The release fractions presented here are for the fission products present after the cooling off period which is allowed for the fuel prior to shipping.

These release fractions represent the total amount of the respective fission products that exist in the gap as a gas and/or as a compound on the surface of the fuel. The largest radiological contributor of these elements is cesium. Recent evidence from the literature $(11,12)$ has suggested that a large portion of the cesium in the gap may exist as a compound of either cesium uranate or cesium molybdate on the surface of the hypostoichiometric $\mathrm{UO}_{2}$ fuel. LWR fuel is typically very close to stoichiometric as fabricated, and during irradiation becomes slightly hypostoichiometric. 
Even though the cesium may not exist as a volatile in the gap for the nonfire case with rod temperatures relatively low, it will still be easily accessible to the sea water in the event of a rod failure. Because of this and the high chemical reactivity of cesium, it is likely that any compound of cesium on the surface of the fuel will be washed away by the sea water within a relatively short amount of time $(<1$ year). Consequently, for this analysis we will assume that those elements present in the rod gap and fuel surface from diffusion will be released to the sea environment immediately following rod failure. The noble fission gases are assumed to be released to the atmosphere. (a)

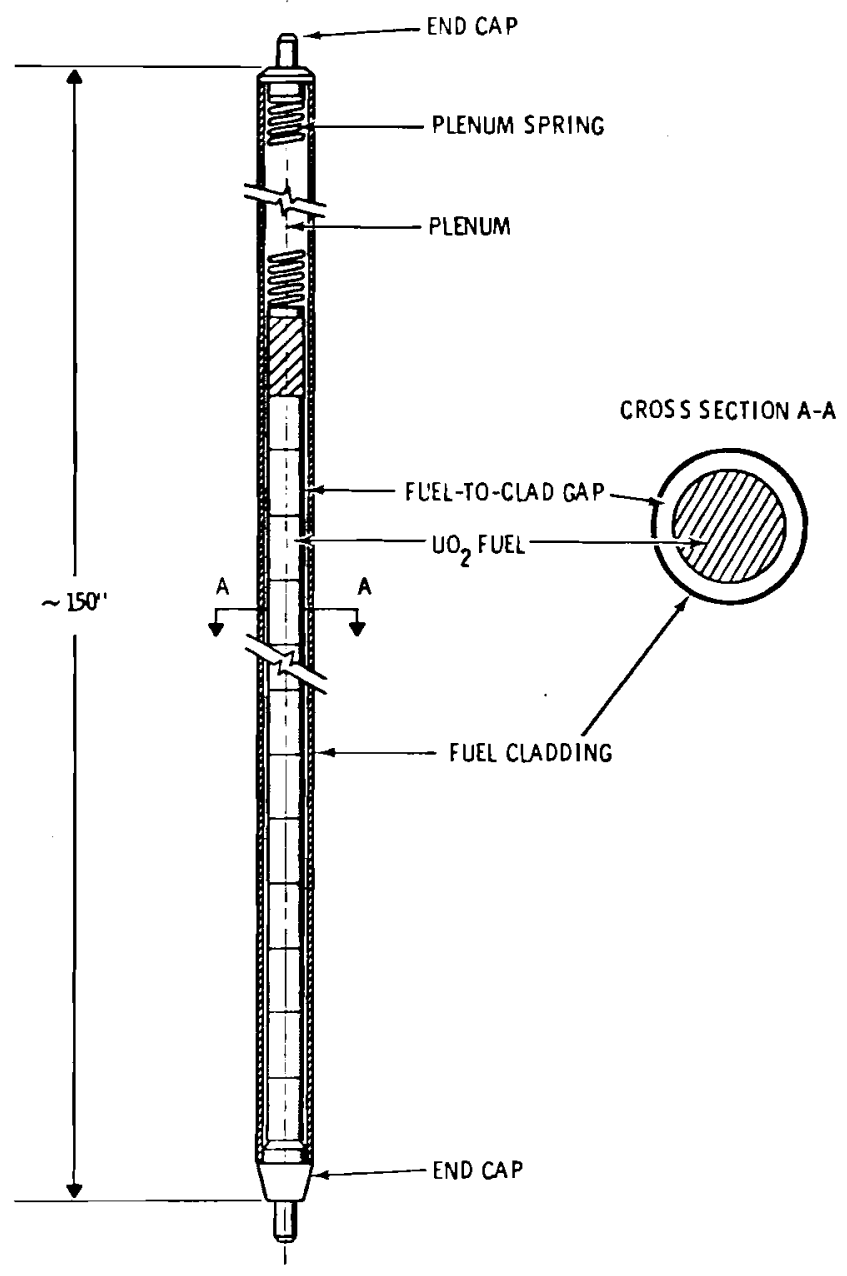

FIGURE 6.2. $\mathrm{UO}_{2}$ Fuel Rod

$\begin{array}{lcc}\begin{array}{c}\text { Elemental } \\ \text { Fission Product }\end{array} & \begin{array}{c}\text { In-Reactor (a) } \\ \text { Release Fraction }\end{array} & \begin{array}{c}\text { Release Fraction } \\ \text { from Cask Fire }\end{array} \\ \mathrm{Sr}, \mathrm{Ba} & 0.01 & (\mathrm{~b}) \\ \mathrm{Te}, \mathrm{Se}, \mathrm{Sb} & 0.10 & (\mathrm{~b}) \\ \mathrm{Xe}, \mathrm{Kr} & 0.08 & (\mathrm{~b}) \\ \mathrm{I} & 0.10 & 0.62 \\ \mathrm{Cs} & 0.15 & 0.89 \\ & & \\ \text { (a) Taken from Reference 10. } & \\ \text { (b) Release fractions not significant. }\end{array}$

(a) The environmental effects of these gases in the atmosphere have not been treated in this study since we are concerned only with those isotopes that enter the marine food chain. 
Thermally activated diffusion is also a very important release mechanism during the $1010^{\circ} \mathrm{C}\left(1850^{\circ} \mathrm{F}\right)$ severe fire. The fuel may reach a nearly uniform temperature of $1090^{\circ} \mathrm{C}\left(2000^{\circ} \mathrm{F}\right)$. At this temperature cesium uranate is expected to disassociate. A fuel rod experiences similiar thermal conditions during a Loss-of-Coolant-Accident (LOCA) with the fuel rod reaching a nearly isothermal temperature of $2000-2200^{\circ} \mathrm{F}$. However, a successfully terminated LOCA is at these temperatures for only a very short period of time (on the order of seconds) in comparison to the possible length of the severe fire at sea (several hours to days). Lorenz and Parker $(13,14)$ measured fission product releases during a simulated LOCA and subsequent rod failure. Their results showed small fractional releases for cesium $(<1 \%)$ and other fission products. However, the rods in their simulated LOCA test were at or above $2000^{\circ} \mathrm{F}$ for less than 150 seconds. In addition, the cesium most likely existed as a nonvolatile compound (such as cesium uranate) prior to the transient. Carl Johnson (Argonne National Laboratory) is currently examining the chemical form of cesium at various temperatures and different fuel conditions. His preliminary results indicate that cesium uranate begins to disassociate above $600^{\circ} \mathrm{C}$. Other cesium compounds such as $\mathrm{Cs}_{2} \mathrm{O}, \mathrm{CsO}_{2}, \mathrm{Cs}_{2} \mathrm{O}_{2}$ vaporize or disassociate at lower temperatures. (15) Consequently, since diffusion and the disassociation of any cesium compounds are rate controlled processes, short term release results are not applicable to the long times at temperatures in this analysis.

Since only a small amount of the fission products were released from the fuel during in-reactor operation, there is a large amount left in the fuel for potential release during the severe fire. To calculate the releases as a result of the fire, we have utilized Booth's $(16)$ model for the release of longlived isotopes, Parker's ${ }^{(17)}$ estimates of the diffusion parameters, and assumed a uniform fuel temperature of $1090^{\circ} \mathrm{C}\left(2000^{\circ} \mathrm{F}\right)$. The resulting diffusion based release fractions are 0.89 for cesium and 0.62 for iodine (Table 6.3). The remaining semivolatiles are relatively immobile at this temperature and their release is insignificant. (Even if the other semi-volatiles were released, their radiological impact is insignificant compared to the cesium release.) The solution to Booth's release model and Parker's estimates of the diffusion parameters are given in Appendix C, Section C.3. 
In addition to thermally activated diffusion, a possible second mechanism that may affect fission product releases during the severe fire is the oxidation by air of the $\mathrm{UO}_{2}$ surface to $\mathrm{U}_{3} \mathrm{O}_{8}$ following rod failure. This reaction is exothermic and may enhance the release of the gaseous and semi-volatile fission products. Parker, et al., have heated small fragments of irradiated $\mathrm{UO}_{2}$ (0.1-0.2 g) to $500-1200^{\circ} \mathrm{C}$ in flowing air for 215 - and 90-min intervals. These tests showed that above $800^{\circ} \mathrm{C}$ the amount released was strongly dependent on time. This is not surprising since both diffusion and the reaction are a thermally activated rate process. A comparison of similar $\mathrm{UO}_{2}$ specimens heated in flowing helium does not show any significant difference, considering the uncertainty in the data, from those heated in air. Furthermore, the fuel surface-to-volume ratio exposed by rod failure in a cask accident will be much smaller than the fuel fragments in Parker's tests. Because of this and the lack of oxidation release data for the long time periods experienced in the severe fire, we will only consider releases due to thermal diffusion during the severe fire.

The total release of volatile fission products for the fire case is obtained by inclusion of both release from in-reactor operation, and cesium and iodine release from fire. These quantities are shown in Table C.3, Appendix C. No hold up of fission products is considered once they are released from the fuel. The clad and cask temperatures are at high enough temperature to prevent plate out on these surfaces; however, once they escape the cask they can plate out on the cooler areas of the ship in addition to falling into the sea. The assumption of no hold up may be a conservative assumption or realistic depending on the amount of plate out and how fast the sea water leaches the fission products from the ship's surface once the ship sinks. For example, if cesium (the largest radiological contributor) were leached away in less than five years, its radiological effect would be essentially the same as if it were released immediately to the sea.

The volatile releases from Table C. 3 have also been used for the case of hydrostatic pressure failure in the deep ocean. This was done to reduce the number of calculations. These releases should not be considered a realistic 
estimate for hydrostatic failure of the rods but rather a conservative upper limit (because cesium release from the fire is included).

\subsubsection{Leaching}

Once the $\mathrm{UO}_{2}$ fuel comes in contact with the sea water, due to fuel rod failure by fire, hydrostatic failure or corrosion, it will be susceptible to leaching and thus, gradually released to the sea environment (Figure 6.1). The leach rates of the fuel will be a function of two phenomena: 1) the effect of ocean currents and 2) chemical leaching. The effect of ocean current on the leach rates will most likely be minimal since the fuel will be encased by two containments, the cask and the fuel cladding, and will not be directly exposed to the currents. In addition, the failures in the cask and the cladding will be relatively small (e.g., seal failures in the cask and cracks in the cladding), further reducing any effect of currents. As a result, we will address only the effects of chemical leaching.

The time span it takes for the $\mathrm{UO}_{2}$ to be consumed by leaching, conservatively assumed to be 450 years, has been divided into several time periods. To get a total radioactive release from leaching, the amount released during the first year and at subsequent 50-year intervals is calculated and numerically integrated over the 450-year time span. These values are given in Table C.4, Appendix $C$. The data and assumptions used to obtain the values in Table C.4 are presented in Appendix C, Section C.4.

The total radiological release from immediate failure is then calculated to be the sum of volatile releases from diffusion (in-reactor plus fire releases) and those from leaching over the 450-year time span (Table C.3). This total is released for calculational purposes during a one-year period to evaluate the total biological dose.

Since all of the rods are assumed to fail immediately in this case, the additional releases associated with immediate cask failure need not be considered. The two terms of the immediate cask failure release are those from the fraction of rods which are failed at time of shipment and the contaminated cooling water. The former is included in the assumption of a 11 rods failed and the latter is small by comparison. 


\subsubsection{Delayed Rod Failure}

The delayed failure occurs in the scenarios consisting of a nonsevere fire and subsequent loss of the cask to the continental shelf. In some cases, as shown in Table 6.2, the cask is assumed to fail immediately due to hydrostatic pressure for this case but the fuel rods will take at least 1000 years for failure. Failure of the cask will allow the ingress of sea water. Assuming that $1 \%$ of the fuel rods discharged from the reactor were failed prior to shipment, the volatile fission products within these failed rods will be washed out to the sea. The semi-volatile releases are calculated from $1 \%$ of the in-reactor release fractions in Table 6.3 and the fission products present within the cask. Since the fuel is not subject to temperatures higher than that experienced in reactor operation, no additional volatiles are driven from the fuel matrix. These values are given in Table C.5, Appendix C.

The fuel from the $1 \%$ failed rods will also be subjected to leaching by the sea water. The releases from leaching are calculated in a similar manner as described for the immediate failure mode except that cesium leaching is proportionately greater for the $1 \%$ failed fuel in this case. This is because the fuel has not been subjected to a severe fire to drive the cesium out as a volatile. The cesium release values for leaching are given in Table C.6, Appendix $C$. The releases from leaching of the remaining isotopes are just $1 \%$ of the values given in Table C.4 and these are given in Table C.7, Appendix C.

As noted above, the remaining fuel rods are assumed to fail in 1000 years due to corrosion. It is further assumed that after failure, the fuel and its contents will be immediately released to the sea environment, neglecting the time it takes to be leached by the sea. This simplifies the calculational effort considerably and does not add a significant amount of conservatism. This is because only the very long-lived isotopes are left after 1000 years and their decay during leaching is not significant. The releases from the 1000 -year failure are then added to the volatile and leaching releases from the $1 \%$ defected rods (Table C.7) to get a total release for the delayed failure. Again, for the radiological impact calculation it is assumed that the total 
amount is released in a single year. This allows a simpler dose calculation and results in approximately an equivalent total population dose. (See Appendix D, page D-2.)

For those cases in which the cask is assumed to be resistant to the continental shelf pressures, the failure of both the cask and the fuel rods is delayed. The total time to failure is taken as 1000 years. The release values are treated the same as those above with the $1 \%$ immediate failure values subtracted. These values are presented in the delayed failure column in Table C.7.

\subsubsection{Effect of Burial in Marine Sediments}

The mechanics of burial of the shipping package in marine sediments is discussed in Appendix B. As is pointed out in that section, the composition of marine sediments varies widely. Likewise, the depth of burial of a falling package also varies. If a package were to bury itself significantly under the sediments, an additional barrier to material releases would be created.

Barriers to material transport would take two forms. The first is absorption of the nuclides by the sediment. The second, which is the rate of physical transport or diffusion through the sediments, can be relatively slow. If the thickness of the covering sediment is great enough, the release rates can approach the radioactive decay rates. (18) This would lead to a significant reduction in the radioactive material released to the marine food chain.

The release values given in Appendix $C$ which are used in the determination of doses in the next section do not take entrainment of radioactive material by marine sediments into account. The values assume free dispersal into the sea after release from the inner containment structures. The severe fire release case is an upper bound and would overestimate the release from a buried spent fuel cask which might fail due to overheating.

\subsection{RADIOLOGICAL IMPACT}

To estimate the radiological impact of the five postulated loss scenarios, release quantity estimates and a biological model are required. The release estimates were given in the preceding section and the characteristics of the ocean environment given in Section 3.3. With these, the impact on marine biota and man can be estimated. 
Calculations were made which model the transport of radionuclides through the marine food chain to man. Calculations were made for each of the five scenarios. The results are given in Table 6.4. Dose and dose commitments are given for the total population and for the average U.S. seafood consuming individual. The dose values are a measure of the radiation received from one year's intake during the same year. Even if no additional contaminated seafood is consumed, there is a certain amount of radioactive material which will be retained by those exposed. This retained material results in a continuing radiation exposure. The dose commitment values give the total irradiation for a 50-year period for the one year's worth of consumption.

The dose derived from the spent fuel cask scenario with severe fire is almost entirely due to ${ }^{134} \mathrm{Cs}$ and ${ }^{137} \mathrm{Cs}$ and is delivered primarily from the initial release in the first year. The remaining release over the next 450 years results in little additional dose.

Since the biological half life of cesium in the body is about 100 days, the 50-year dose commitment is only a little larger than the dose during the uptake period. The dose from a fuel cask which started to leak after 1000 years in the ocean (continental shelf, nonsevere fire scenario) would be primarily from ${ }^{240} \mathrm{Pu}$ and ${ }^{241} \mathrm{Am}$. Since these nuclides have a very large effective half life in the body (170 and 49 years, respectively), the 50-year dose commitments are considerably larger than the dose received during the year of intake.

The deep ocean values are scaled from the case of an extended fire on the continental shelf. The scaling is based on the difference of seafood productivity by a factor of 1000 between the continental shelf and deep ocean. There are further reducing factors. Some of the deep ocean releases occur at great depths. The transport of radionuclides from these depths into man's environment is very slow. Dispersion and decay would reduce their impact. In all but the extended fire case, high temperatures do not exist prior to loss to drive semi-volatiles to the gap. This further reduces the material release rate and consequently the dose. 
TABLE 6.4. Estimated Dose from Contaminated Seafood Consumption after the Loss at Sea of a Spent Fuel Cask Containing 3.1 MT Uranium

Total Population

\begin{tabular}{|c|c|c|c|c|c|}
\hline \multirow[b]{2}{*}{ Location of Loss } & \multirow[b]{2}{*}{ Pre-Loss Damage } & \multicolumn{2}{|c|}{$\begin{array}{c}\text { Dose } \\
\text { (man-rem) }\end{array}$} & \multicolumn{2}{|c|}{$\begin{array}{l}\text { Dose Commitment } \\
\text { (man-rem) }\end{array}$} \\
\hline & & Fish & Sea food $(a)$ & Fish & Sea food $(a)$ \\
\hline Continental shelf & $\begin{array}{l}\text { Undamaged, minor fire, moderate } \\
\text { fire, cask not pressure resis- } \\
\text { tant }(b)\end{array}$ & 150 & 160 & 270 & 1000 \\
\hline Continental shelf & $\begin{array}{l}\text { Undamaged, minor fire, cask pres- } \\
\text { sure resistant }\end{array}$ & $\sim 2$ & $\sim 15$ & $\sim 35$ & $\sim 765$ \\
\hline Continental shelf & Severe fire & $8.9 \times 10^{4}$ & $8.7 \times 10^{4}$ & $1.5 \times 10^{5}$ & $1.5 \times 10^{5}$ \\
\hline Deep ocean & Undamaged, minor fire, moderate fire & $<150$ & $<150$ & $<150$ & $<150$ \\
\hline Deep ocean & Severe fire & $<150$ & $<150$ & $<150$ & $<150$ \\
\hline \multicolumn{6}{|c|}{ Average Individual } \\
\hline \multirow[b]{2}{*}{ Location of Loss } & \multirow[b]{2}{*}{ Pre-Loss Damage } & \multicolumn{2}{|c|}{$\begin{array}{c}\text { Dose } \\
\text { (man-rem) }\end{array}$} & \multicolumn{2}{|c|}{$\begin{array}{c}\text { Dose Commitment } \\
\text { (man-rem) }\end{array}$} \\
\hline & & Fish & Seafood (a) & Fish & Seafood (a) \\
\hline Continental shelf & $\begin{array}{l}\text { Undamaged, minor fire, moderate } \\
\text { fire, cask not pressure resis- } \\
\text { tant }\end{array}$ & $1.7 \times 10^{-4}$ & $1.8 \times 10^{-4}$ & $3.1 \times 10^{-4}$ & $1.1 \times 10^{-3}$ \\
\hline Continental shelf & $\begin{array}{l}\text { Undamaged, minor fire, cask pres- } \\
\text { sure resistant }\end{array}$ & $\sim 2.0 \times 10^{-6}$ & $\sim 2.0 \times 10^{-5}$ & $\sim .0 \times 10^{-5}$ & $\sim 9.0 \times 10^{-4}$ \\
\hline Continental shelf & Severe fire & $1.0 \times 10^{-1}$ & $1.0 \times 10^{-1}$ & $1.7 \times 10^{-1}$ & $1.7 \times 10^{-1}$ \\
\hline Deep ocean & Undamaged, minor fire, moderate fire & $<1.7 \times 10^{-4}$ & $<1.7 \times 10^{-4}$ & $<1.7 \times 10^{-4}$ & $<1.7 \times 10^{-4}$ \\
\hline Deep ocean & Severe fire & $<1 . .7 \times 10^{-4}$ & $<1.7 \times 10^{-4}$ & $<1.7 \times 10^{-4}$ & $<1.7 \times 10^{-4}$ \\
\hline
\end{tabular}

(a) Mix of $50 \%$ fish, $25 \%$ crustaces, and $25 \%$ molluscs.

(b) Include initial 1\% failed fuel ( 150 man-rem dose and 2235 man-rem dose commitment for either fish or seafood) and eventual release from corrosion failure of fuel rods. 
The worst case examined is the extended fire followed by the loss to the continental shelf. This results in a population dose of $1.5 \times 10^{5}$ man-rem. Some $60 \%$ of this dose commitment is incurred in the first year. The average individual dose is 0.17 rem. This is only a little more than the annual dose received from average natural background radiation.

As in the plutonium case (see Section 5.3), the postulated losses are unlikely to have any serious impact on the marine ecosystem. It is important to realize that in the case of biota the concern is for populations, so that individual mortality or morbidity is not of interest except as it affects the population. Even if some of the biota are killed in the immediate area, their loss to the population from a reproductive success point of view, will be insignificant. A comparable field situation, for example, is in the vicinity of the radioactive discharge from the BNFL chemical reprocessing plant on the north-east Irish Sea, where dose rates have a maximum value of perhaps 0.6 $\mathrm{rad} /$ day. At this level of exposure, examination of the stocks of the bottom living plaice, Pleuonectes platessa, over seven years, provide no evidence that there has been any adverse effect on this stock. ${ }^{(5)}$ 


\subsection{OTHER CONSIDERATIONS IN THE LOSS OF PACKAGES AT SEA}

The consequence calculations presented in the previous sections can be placed in better perspective by investigating the probability of sinking a large cargo vessel and the possibility of recovering a radioactive material shipping package lost into the sea. These two issues are explored in this section.

\subsection{LIKELIHOOD OF LOSS}

The likelihood of losing a radioactive material shipping container at sea can be investigated by examining the frequency of the loss of large cargo vessels. These numbers will be directly related if the reasonable assumption is made that the shipping container is well secured to the vessel so that the vessel must suffer severe damage or sink before the package can be lost into the sea.

The summary of world-wide vessel losses presented in Table 7.1 was obtained from Lloyd's Register of Shipping. The probability of vessel loss per vessel year, per GRT ${ }^{(a)}$ year, and per vessel kilometer is given in the table. Loss of the vessel is defined as either sinking or damage severe enough to cause the vessel to be scrapped. To estimate the probability of loss per vessel kilometer, it is assumed that each vessel travels $96,000 \mathrm{~km}$ per year.

A more detailed examination of the 1974 summary yields several interesting observations. Of the 311 vessels lost, 86 were fishing vessels. Only 23 lost vessels were over 9,000 gross metric tons and 161 were under 450 gross metric tons. This would indicate that the smaller vessels tend to bias the vessel loss probabilities. A comparison of loss probabilities by vessel year and by GRT year confirms this.

A vessel of 1000 tons or more would probably be required to ship a spent fuel cask. It is likely that plutonium shipments, while not requiring a large vessel from a capacity standpoint, would also be shipped on a large vessel. Table 7.2 shows the total number of vessels lost and those lost through fire by (a) Million gross metric tons. 
size for 1974. Unfortunately data giving the number of vessels in service by size is not available. Therefore, the probability of loss by vessel size can not be calculated. As mentioned before, the data available indicite that the probability of loss for all vessels is biased by a predominance of loss of smaller vessels. If then the probabilities for all vessels are applied to vessels large enough to carry nuclear materials, the results will be conservative.

The number of vessels lost by nation of registry makes an interesting comparison of loss, as demonstrated in Table 7.3. This may reflect the maritime regulations of the nations of registry. If so, it would indicate that a well certified vessel and crew can significantly reduce the probability of loss.

The significance of the loss probabilities can be shown by a simple example. If a nuclear material carrying vessel makes five round trips across the Pacific in a year, its total travel will be approximately $96,000 \mathrm{~km}$. Based on the Lloyd's data, the probability of loss on any round trip is $1 \times 10^{-3}$ and the probability of a severe fire per round trip is $2 \times 10^{-4}$. Again, this data is biased high with small vessels.

TABLE 7.1. Summary of Merchant Ships Totally Lost:

1970 to 1974

\begin{tabular}{|c|c|c|c|c|c|c|c|}
\hline \multirow[b]{2}{*}{ Year } & \multicolumn{2}{|c|}{ In Service } & \multicolumn{2}{|c|}{ Totally Lost } & \multirow{2}{*}{$\begin{array}{l}\text { Probability of } \\
\text { Loss/Vessel Year }\end{array}$} & \multirow{2}{*}{$\begin{array}{l}\text { Probability of } \\
\text { Loss/GRT(a) Year }\end{array}$} & \multirow{2}{*}{$\begin{array}{l}\text { Probability of } \\
\text { Loss/Vessel } \mathrm{km}\end{array}$} \\
\hline & No. & GRT(a) & No. & GRT(a) & & & \\
\hline 970 & 52,444 & 206 & 352 & 0.55 & $6.7 \times 10^{-3}$ & $2.68 \times 10^{-3}$ & $7.0 \times 10^{-8}$ \\
\hline 971 & 55,041 & 225 & 377 & 0.93 & $6.9 \times 10^{-3}$ & $4.17 \times 10^{-3}$ & $7.1 \times 10^{-8}$ \\
\hline 1972 & 57,391 & 244 & 371 & 0.86 & $6.5 \times 10^{-3}$ & $3.54 \times 10^{-3}$ & $6.8 \times 10^{-8}$ \\
\hline 1973 & 59,606 & 264 & 363 & 0.84 & $6.1 \times 10^{-3}$ & $3.17 \times 10^{-3}$ & $6.4 \times 10^{-8}$ \\
\hline 1974 & 61,194 & 283 & 311 & 0.79 & $5.1 \times 10^{-3}$ & $2.79 \times 10^{-3}$ & $5.3 \times 10^{-8}$ \\
\hline
\end{tabular}

(a) MitTion gross metric tons 
TABLE 7.2. Summary of Merchant Ships Totally Lost

and Those Lost through Fire by Size - 1974

\begin{tabular}{|c|c|c|c|c|c|c|c|c|c|c|c|c|}
\hline How Lost & $\begin{array}{l}\overline{90} \\
\text { to } \\
450 \\
\end{array}$ & $\begin{array}{l}450 \\
\text { to } \\
900 \\
\end{array}$ & $\begin{array}{c}900 \\
\text { to } \\
1,800 \\
\end{array}$ & $\begin{array}{c}1,800 \\
\text { to } \\
3,600 \\
\end{array}$ & $\begin{array}{r}3,600 \\
\text { to } \\
4,500 \\
\end{array}$ & $\begin{array}{r}\mathrm{Me} \\
4,500 \\
\text { to } \\
7,200 \\
\end{array}$ & $\begin{array}{c}\text { ric Tor } \\
7,200 \\
\text { to } \\
9,000\end{array}$ & $\begin{array}{c}\text { Gross } \\
9,000 \\
\text { to } \\
14,000 \\
\end{array}$ & $\begin{array}{c}14,000 \\
\text { to } \\
18,000 \\
\end{array}$ & $\begin{array}{c}18,000 \\
\text { to } \\
27,000 \\
\end{array}$ & $\begin{array}{c}27,000 \\
\text { and above } \\
\end{array}$ & Total \\
\hline Lost by Fire & 18 & 8 & 5 & 8 & 3 & 1 & 1 & 4 & 1 & 1 & 1 & 51 \\
\hline Total Lost & 161 & 35 & 26 & 35 & 14 & 9 & 8 & 12 & 4 & 3 & 4 & 311 \\
\hline
\end{tabular}

TABLE 7.3. Ships Totally Lost 1974 by Nation of Registry

\begin{tabular}{|c|c|c|c|c|}
\hline Flag & Number & $\begin{array}{l}\text { Metric } \\
\text { Tons } \\
\text { Gross } \\
\end{array}$ & $\begin{array}{l}\text { Percentage } \\
\text { of Nation's } \\
\text { Ships } \\
\end{array}$ & $\begin{array}{l}\text { Percentage } \\
\text { of Nation's } \\
\text { Gross Tons } \\
\end{array}$ \\
\hline Cyprus & 18 & 47,200 & 2.49 & 1.53 \\
\hline Singapore & 7 & 37,000 & 1.37 & 1.42 \\
\hline $\begin{array}{l}\text { Fed. Rep. of } \\
\text { Germany }\end{array}$ & 19 & 108,200 & 0.72 & 0.55 \\
\hline U.S.A. & 16 & 36,700 & 0.39 & 0.28 \\
\hline U.K. & 15 & 23,300 & 0.42 & 0.08 \\
\hline
\end{tabular}

\subsection{RECOVERY}

The biological effects given in the earlier sections assume the shipping containers are lost without recovery. This need not be the case. Depending on the conditions of the loss event, an expeditious recovery effort could significantly mitigate ecological damage.

Technology currently exists that allows location and recovery of large objects from almost any point on the ocean floor. Miniature submarines known as Deep Submergence Vehicles have been developed which have greatly enhanced our capabilities on the ocean floor. A partial list of these vessels, with operational depths, would include BEAVER MARK IV $(610 \mathrm{~m})$, PISCES VI $(2000 \mathrm{~m})$, ALVIN $(3700 \mathrm{~m})$, and TRIESTE II $(11,000 \mathrm{~m})$. Remote searching equipment and large scale recovery vessels have made similar advances. There are several examples of the application of this technology. 
In 1963, the nuclear submarine THRESHER sank in 2590 meters $(8500 \mathrm{ft})$ of water. After the vessel was located, sediment samples and debris were collected froln the area. A nuclear weapon lost in 610 meters $(2000 \mathrm{ft})$ of water near Palomares, Spain was located and recovered. Two deep submergence vehicles, the ALVIN and ALUMINANT, were employed in the search.

The location of the nuclear submarine SCORPION lost in 1968 was more difficult. The date of her sinking is uncertain within an 8-day period. The last radio transmission received from the SCORPION came from near the Azores. A search was conducted along the expected course of the vessel, beginning at that point. Five months after the sinking, the $i l l$ fated craft was located in 3050 meters $(10,000 \mathrm{ft})$ of water 400 miles southwest of the Azores. The Navy research ship MIZAR located the SCORPION using a deep sea television and camera array towed slowly just above the ocean floor.

The recent survey ${ }^{(19)}$ of radioactive waste disposal sites further demonstrates the effectiveness and flexibility of submersible vehicles. The unmanned CURV III vehicle was used at the Pacific Farallon Islands site at depths as great as $1700 \mathrm{~m}(5580 \mathrm{ft})$ to locate and survey the condition of 210- $\ell$ radioactive waste containers dumped there between 1946 and 1965 . The CURV III is equipped with television cameras, a $35 \mathrm{~mm}$ camera, a $120^{\circ}$ scarning sonar system capable of detecting a 55-gal drum at $400 \mathrm{~m}$, and a manipulating arm.

The ALVIN was used at the Atlantic radioactive waste dumpsite which was located at a depth of $2800 \mathrm{~m}(9190 \mathrm{ft})$. This three-man craft has a television camera, two externally mounted $35 \mathrm{~mm}$ cameras, a sonar system capable of detecting a 55-gal drum at a horizontal distance of $350 \mathrm{~m}$, and a highly sophisticated manipulating arm.

In conducting this survey, the approximate location of the dumpsite was known but a search had to be made for the exact location and individual waste drums found. This search was successful in both the Atlantic and Pacific sites. Individual drums were inspected and samples of the ocean floor material taken. Analyses of these samples were able to detect plutonium in amounts less than $1 \mathrm{pCi} / \mathrm{kg}$ of sediments and ${ }^{137} \mathrm{Cs}$ on the order of $10 \mathrm{pCi} / \mathrm{kg}$. 
In 1976, the Office of Radiation Programs of the U.S. Environmental Protection Agency actually recovered a $300-\ell(500 \mathrm{~kg})$ radioactive waste container from a depth of $2800 \mathrm{~m}$ to study the corrosion rate of the metal drum and the degradation and leach rates of the concrete matrix. ${ }^{(20)}$ This is the first example of such a package recovery being made, but it clearly indicates that the technology for recovering waste packages in the deep sea presently exists.

A more dramatic example is the reported partial recovery of a Russian submarine by the GLOMAR EXPLORER. This recovery was made from a depth of 5500 meters $(18,000 \mathrm{ft})$. This demonstrates that given sufficient time and money few losses to the sea would be irrecoverable. The difficulty encountered in recovery is dependent on water depth and how precisely the point of sinking is known. It is reasonable to assume that given minimal information a lost ship could be located. Several methods could be employed to expedite location. Satellite navigation and continuous communication could fix the loss point to within tenths of a mile. Sonar beacons on the shipping containers would also speed location.

There are two special cases which could increase the difficulty of location and recovery. Both are based on the unlikely possibility that the package is separated from the ship. The first is the possibility of a package being covered by marine sediments. Since a great deal of undersea location is done by visual detection the camouflage provided by any covering would magnify the problem of location. (a)

Another special case is the possibility of a floating 6M container. Separation of package from the ship would increase the area to be searched and decrease the size of the object of the search. This case is not considered to be very likely. First of all the plutonium package will likely be stored below deck. The accident which causes the loss must somehow set the package free onto the ocean. Then the package must float. A 6M container with waterlogged fiberboard will sink. The difficulty arises in the time required to (a)The potential burial depths discussed in Appendix B could make location
and recovery very difficult. 
sufficiently waterlog the fiberboard. It is reasonable to assume the outer drum of the 6M container leaks. However, just how long it takes for the fiberboard to absorb enough water to sink the package and how far the package drifts in that time is difficult to determine. It is not incredible that a $6 \mathrm{M}$ container could float long enough to be washed ashore.

The expense of recovery is dependent on the depth and weight of the lost item. A large recovery operation might be required to raise a spent fuel cask from the deep ocean. A 6M container might be recovered from shallow water by a small DSV vesse1. Other factors would complicate recovery. If the container is within a sunken ship, removing the container would be difficult. Special care would be required if the container were leaking its contents.

The mitigation of biological effects is dependent on the loss events. If the release is immediate, recovery is pointless. If, however, the loss event is slow or release does not occur until after many years, recovery could significantly reduce the damage. Table 7.4 below suggests the relative effectiveness of recovery on each loss event.

\section{TABLE 7.4. Relative Effectiveness of Recovery} of Lost Shipping Containers

\begin{tabular}{|c|c|c|c|}
\hline Container & Pre-Loss Damage & Lost To & $\begin{array}{l}\text { Impact Mitigation } \\
\text { by Recovery }\end{array}$ \\
\hline Cask & None - Moderate Fire & Deep Ocean & Some \\
\hline Cask & None - Moderate Fire & Cont. Shelf & Significant \\
\hline Cask & Severe Fire & Deep Ocean & Little \\
\hline Cask & Severe Fire & Cont. Shelf & Little \\
\hline $6 M$ & & Deep Ocean & Potential \\
\hline $6 M$ & & Cont. Shelf & Potential \\
\hline
\end{tabular}

It should be pointed out that while in the estimation of doses it was assumed all the plutonium in a lost 6M container is released in a single year, this is probably not the case. It is likely that the release could be slow enough that prompt recovery could have a significant mitigating effect. The 
effect of burial of a spent fuel cask in marine sediments is also an interesting, if unlikely, case. It is possible that such burial would bring a relatively quick thermal-induced failure of the fuel rods. The resulting effect would be partially offset by entrainment of the radioactive material in the sediments. However, what the trade off is and how effective recovery would be is unknown.

Table 7.4 simply portrays the relative gain by removing the lost package from the ocean floor. That removal process itself is not considered. It is assumed that precautions would be taken during the recovery operation to prevent increasing the dispersal of radioactive materials. 
• 


\section{REFERENCES}

1. Hempe1, G., "Productivity of the Oceans", Journal of the Fisheries Research Board of Canada, Vol. 30, No. 12, part 2, December 1973.

2. Clarke, R. K., J. T. Foley, W. F. Hartman and D. W. Larson, Severities of Transportation Accidents, SLA 74-0001, Sandia Laboratories, A1buquerque, NM, July 1976.

3. Patterson, Nelson, Matlack, The Dissolution of ${ }^{238} \mathrm{Pu}$ in Environmental and Biological Systems, LA-5624, 1974.

4. Lai and Goya, "Radioactivity Release from Radionuclide Powder Sources Part III Release from Plutonium Metal to Seawater", USNRDL-TR-1050, 1966.

5. IAEA, "Effects of Ionizing Radiation on Aquatic Organism and Ecosystems", IAEA, No. 172, Vienna, 1976.

6. Terado, 0., et a1., "Collapse Test of a Model Shipping Cask Under High External Pressure", IAEA, Vienna, 1976.

7. Butler, G., and H. C. K. Ison, Corrosion and Its Prevention in Water, Reinhold Publishing Corporation, New York, NY, 1966.

8. Reihart, F., "Corrosion of Materials in Hydrospace", U.S. Naval Civil Engineering Laboratory, Technical Report R-504.

9. Bel1, M. J., "ORIGEN - The ORNL Isotope Generation and Depletion Code", ORNL-4628, Oak Ridge National Laboratory, Oak Ridge, TN, May 1973.

10. Ritzman, R. L., et al., Release of Radioactivity in Reactor Accidents, WASH-1400 (NUREG-75/014) Appendix VII, Reactor Safety Study, October 1975 .

11. Lambert, J. D. B., L. A. Niemark and R. V. Strain, "Failure Mechanism in Mixed Oxide Fuel Elements", ANS Transaction, 17, p. 193-194, 1973.

12. Johnson, Irving, and Carl Johnson, "Migration of Cesium and Molybdenum in Irradiated Oxide Fuels", IAEA Symposium, Vienna, p. 21-25, 0ctober 1974.

13. Lorenz, R. A., D. 0. Hobson, G. W. Parker, "Final Report on the First Fuel Rod Failure Transient Test of a Zircaloy-Clad Fuel Rod Cluster in TREAT", Oak Ridge National Laboratory, ORNL-4635, March 1971.

14. Osborne, M. F., and G. W. Parker, "Rupture Tests of Irradiated Fuel Rods", in Nuclear Safety Program Annual Progress Report, for period ending December 31, 1970, ORNL-4647, May 1971. 
15. Lorenz, R. A., et a1., Behavior of Iodine, Methyl Iodide, Cesium 0xide and Cesium Iodine in Steam and Argon, ORNL/NUREG/TM-25.

16. Booth, A. H., A Method of Calculating Fission Gas Diffusion from UO Fuel and Its Application to the X-2-F Loop Test, CRDC-721, 1957.

17. Parker, G. W., "Calculation of Gap Release of Radioactive Fission Products", WASH-1400 (NUREG-75/014) Appendix C of Appendix VII, Reactor Safety Study, October 1975.

18. "High-level Radioactive Waste Management Alternatives - Seabed Disposal", BNWL-1900, Battelle, Pacific Northwest Laboratories, Richland, WA, May 1974.

19. Dyer, R. S., "Environmental Surveys of Two Deep Sea Radioactive Waste Disposal Sites Using Submersibles", International Symposium on the Management of Radioactive Waste from the Nuclear Fuel Cycle IAEA-SM207165, March 1976.

20. "ALVIN Participates in Retrieval of Radioactive Waste Container", Woods Hole Notes, Vol. 8, No. 3, October 1976. 


\section{FAILURE THRESHOLDS IN THE SEA}

Sections 5.1 and 6.1 discussed the failure thresholds of the packages to the forces of corrosion and hydrostatic pressure. This appendix presents the details of the analysis giving these thresholds.

\section{A.1 FAILURE THRESHOLD OF THE 6M PACKAGE BY HYDROSTATIC PRESSURE}

Analysis of the $6 \mathrm{M}$ container was 1 imited to the inner $2 R$ containment vessel shown in Figure 4.1. It was assumed that the outer drum would buckle and permit leakage part the lid at only a few atmospheres of hydrostatic pressure. One end of the inner container is sealed with a pipe plug. It is very difficult to determine the leak-tightness of this plug. In standard piping applications, such plugs are capable of withstanding very high pressures. The sealing action of the plug is limited in the inner container application by the difficulties encountered in obtaining a leak-tight fit while assembling the container. However, for the first analysis, it was assumed that the inner container was adequately sealed to prevent flow and an estimate made for the vessel collapse pressure. The dimensions used for the inner container were $12.23 \mathrm{~cm} \mathrm{ID}, 0.95 \mathrm{~cm}$ wall thickness ( 5 in. Schedule 80 ) steel pipe approximately $30.48 \mathrm{~cm}$ (12 in.) long. The inner vessel was treated as thick-walled cylinder. The buckling or collapse of this cylinder will most likely be caused by yielding the fibers. The expression below was used to calculate the critical pressure at the yield point.

$$
P_{y \cdot p \cdot}=\frac{t}{R} \frac{\sigma_{y \cdot p \cdot}}{1+4 \frac{\sigma_{y} \cdot p \cdot \frac{R^{2}}{E}}{t^{2}}}
$$


where:

$$
\begin{aligned}
P_{y \cdot p_{.}} & =\text {critical pressure at yield point } \\
t & =\text { vessel wall thickness } \\
\mathrm{R} & =\text { radius } \\
\sigma_{y \cdot P_{.}} & \text {yield point stress } \\
\dot{E} & =\text { modulus of elasticity }
\end{aligned}
$$

Another approach was analyzed by utilizing a special case of Lame's equations for thick-walled cylinders as shown below:

$$
P_{L a}=\frac{\sigma_{y} \cdot p \cdot\left(O D^{2}-I D^{2}\right)}{20 D^{2}}
$$

where:

$$
\begin{aligned}
P_{L a} & =\text { critical pressure using Lame's equation } \\
O D & =\text { Outside Diameter } \\
I D & =\text { Inside Diameter }
\end{aligned}
$$

The following estimated range was obtained for the collapse pressures:

$$
\begin{aligned}
P_{y . p .} & =286.1 \mathrm{~atm}(4205 \mathrm{psi}) \text { using Equation A.1 } \\
P_{\text {La }} & =308 \mathrm{~atm}(4526 \mathrm{psi}) \text { using Equation A.2 }
\end{aligned}
$$

Neglecting internal cavity gas pressure, the range of ocean depths corresponding to the pressures above lies between approximately 2835 meters $(9300 \mathrm{ft})$ and 3071 meters $(10,000 \mathrm{ft})$.

However, collapse of the $2 R$ vessel walls is not expected to be the normal failure mode for this package. At low external pressure the $2 \mathrm{R}$ container would probably experience limited entry of sea water (or pressure equilization) would probably be high enough to prevent collapse of the containment vessel. The inner cans containing the plutonium dioxide would collapse under a very low differential pressure (less than 2 atmospheres). Thus, sea water would probably penetrate the inner vessel past the seal and threads at depths encountered on the continental shelf $(200 \mathrm{~m})$. The pressure would collapse the inner cans, and allow the sea water to mix with the plutonium oxide. 


\section{A.2 FAILURE THRESHOLD OF THE 6M PACKAGE BY CORROSION}

The 6M container is shown in Figure 4.1. The outer drum is constructed of 18 gauge steel. The inner $2 R$ container is expected to be a $12.7 \mathrm{~cm}$ (5 in.) diam Schedule 80 steel pipe [wall thickness $0.9525 \mathrm{~cm}(0.375$ in.)]. The welded end cap is $1.27 \mathrm{~cm}$ ( 0.5 in.) thick steel plate and a threaded pipe plug approximately $3.302 \mathrm{~cm}(1.3 \mathrm{in}$.) long closes the vessel. The contents of the $6 \mathrm{M}$ do not generate significant heat; therefore, the entire assembly is assumed to remain at the ambient sea water temperature while submerged. Upon submergence, the outer steel drum would presumably buckle at less than two atmospheres hydrostatic pressure. The Celotex insulation would presumably remain essentially in place around the $2 R$ inner containment vessel.

The results of many investigations around the world in surface sea water show that after a short initial exposure, the corrosion rates for structural steels is between $0.08 \mathrm{~mm}(3 \mathrm{mils})$ and $0.13 \mathrm{~mm}$ ( $5 \mathrm{mils}$ ) per year. (1) Exposure tests by the U.S. Naval Civil Engineering Laboratory in water depths to approximately 1829 meters $(6000 \mathrm{ft})$ indicate that virtually all common steels corrode uniformly at rates below those encountered in near-surface waters. Therefore, it is assumed that the $6 M$ inner container will corrode at a uniform rate of $0.08 \mathrm{~mm}$ per year on either the continental shelf or at great ocean depths.

Water leaking past the seal is assumed to have corroded the inner cans away long before the $2 R$ vessel fails. The predicted life of the vessel before failure by corrosion is simply the thickness divided by the rate of $0.08 \mathrm{~mm}$ per year. In the case of a $12.7-\mathrm{cm}(5-\mathrm{in}$.$) diam Schedule 80$ pipe, the expected life is $0.9525 \mathrm{~cm}(0.375 \mathrm{in.}) \div 0.008 \mathrm{~cm}(0.003$ in.)/year, or 125 years. Modes of corrosion other than general wasting, such as pitting and crevice corrosion, are not commonly encountered in carbon steels and are not expected in the case of the $6 \mathrm{M}$ container. Unusual oceanographic conditions or marine fouling could accelerate the corrosion rate. However, this is not expected to be significant.

Even at accelerated rates corrosion is not expected to be the primary mode of failure for the $6 \mathrm{M}$ package. As discussed earlier, leakage into the 
inner container is likely to occur at even shallow depths. While corrosion will eventually destroy the package, its containment function will long before have been subverted.

\section{A.3 FAILURE THRESHOLD OF THE SPENT FUEL CASK BY HYDROSTATIC PRESSURE}

There are two stages of failure by hydrostatic pressure of an intact cask. The first is the failure of the cask itself as a pressure vessel. This is expected to take the form of failure of the pressure relief devices or leakage around the cask closure seals. The second stage of failure is the ultimate collapse of the individual fuel rods.

\section{A.3.1 Spent Fuel Cask Seals and Pressure Relief Devices}

Presșure relief devices are provided on typical spent fuel casks to limit internal pressure. If this pressure reaches a certain value, the pressure relief devices on the cask will vent. Pressure relief devices are usually rupture disks or relief valves. The rupture disks and some of the relief valves operate on a differential pressure. That is, when the pressure on one side exceeds that on the other by a preset amount, they vent. This implies that if the set point is 27.2 atm (400 psi), an external pressure which exceeds the inner pressure by 27.2 atm would be required to fail such pressure relief devices.

0ther types of relief valves operate differently. Some may be highly resistant to external pressures. Closure seals are also of different types. Many of these are quite resistant to external pressures while others are less resistant. Another factor is fire damage. Organic seals in particular may be sensitive to heat and be damaged in fire.

With the variety of closure seals and pressure relief devices, it is not possible to define a "typical" failure threshold for a "typical" spent fuel cask. Therefore, two possible cases were considered. The first case is a cask with a rupture disk set to 27.2 atm (400 psi) with low internal pressure (for instance cooled by immersion in cool sea water). Rupture disks are not precise devices so it is assumed that at an external pressure 
of $27.2 \mathrm{~atm}$ (400 psi) it fails. This would occur at a depth of 260 meters $(870 \mathrm{ft})$ which implies a failure near the continental shelf depth of 200 meters.

The second case is that of a cask with pressure resistant closure seals and relief devices. If we assume the closure seals and pressure relief devices hold, the cask wall itself will finally succumb when the hydrostatic pressure is great enough. A calculation was made to estimate the failure threshold of a typical cask. The following are the values assumed in the evaluation of the performance of a stainless steel spent fuel cask:

$$
\begin{aligned}
& u \text { (Poissions ratio })=0.3 \\
& E\left(\text { modulus of elasticity) }=1.97 \times 10^{6} \mathrm{~atm}\left(29 \times 10^{6} \mathrm{psi}\right)\right. \\
& \sigma_{y . p .} \text { (yield point stress of stainless steel) }=2449.7 \mathrm{~atm} \\
& (36,000 \mathrm{psi})
\end{aligned}
$$

$$
\begin{aligned}
& \text { Length of Cask }=431.8 \mathrm{~cm}(170 \mathrm{in.}) \\
& O D=127 \mathrm{~cm}(50 \text { in.) } \\
& t(\text { wa } 11 \text { thickness })=3.81 \mathrm{~cm}(1.5 \mathrm{in.}) \\
& I D=119.38 \mathrm{~cm}(47 \text { in.) } \\
& R=61.60 \mathrm{~cm}(24.25 \text { in.) }
\end{aligned}
$$

The critical presslire based on the modulus of elasticity $\left(P_{\mathrm{cr} . \mathrm{E}}\right)$ was found to be acceptable in estimating the cask's collapse pressure.

$$
P_{c r . E}=\frac{E t^{3}}{4\left(1-u^{2}\right) R^{3}}
$$

This approach implies that the cask can be treated as a thin-walled cylinder. The resulting cask collapse pressure value obtained from the above equation is $128.3 \mathrm{~atm}$ (1885 psi). An additional allowance of $20 \%$ was estimated to accommodate for any possible stiffening effects produced by the lead or uranium shielding. An additional allowance was made for a possible $13.6 \mathrm{~atm}$ (200 psi) internal pressure. Therefore, it is estimated that the cask will collapse when it experiences an external hydrostatic pressure of $167.6 \mathrm{~atm}$ (2463 psi) as it descends through the ocean depths. 
The corresponding ocean depth at which point the cask could fail is approximately 1672 meters $(5485 \mathrm{ft})$. In this case the cask would not fail on the continental shelf but would fail in the deep ocean.

\section{A.3.2 Spent Fuel Rods}

We can assume from the above that for depths either at or below the continental shelf the cask can be flooded with sea water. This means the fuel rods within the cask are exposed to the ocean's hydrostatic pressure. Failure thresholds for two types of light water reactor fuel subjected to this pressure were calculated.

The two types of reactor fuel considered are the Pressurized Water Reactor (PWR) fuel and the Boiling Water Reactor (BWR) fuel. Both types of fuel rods are similar in that they are long thin tubes of Zircaloy packed with uranium.

The Zircaloy tubing which surrounds the pellets is referred to as the cladding. At one end of the tube is a void space or plenum to allow for gasses generated in the fission process. Generally the BWR rods have a greater diameter and clad thickness. Typical material properties and dimensions for LWR fuel rods are shown in Table A.1.

\section{TABLE A. 1. Typical Material Properties and} Dimensions for LWR Fuel Rods

$$
\begin{aligned}
& \mu \text { (Poissions ratio) } \\
& E \text { (modulus of elasticity of Zircaloy \#4) } \\
& \sigma_{Y . P .} \text { (yield stress for Zircaloy \#4) } \\
& \sigma_{\text {P.L. }} \text { (proportional 1 imit) }
\end{aligned}
$$

$$
\begin{aligned}
= & 0.33 \\
= & 0.6805 \times 10^{6} \mathrm{~atm} \\
& \left(10 \times 10^{6} \mathrm{ps} i\right) \\
= & 4082.8 \mathrm{~atm} \\
& (60,000 \mathrm{ps} \mathrm{i}) \\
= & 2858 \mathrm{~atm} \\
& (42,000 \mathrm{psi})
\end{aligned}
$$

PWR

BWR 
The fuel rods will probably fail by collapsing inward about the diameter at the upper or gas-filled end. This collapse is a form of an inward buckling of a circular tube. The following equation, utilized to determine a critical pressure to fail the rod, is based primarily on the material's modulus of elasticity.

$$
P_{\text {C.r.E }}=\frac{E}{4\left(1-\mu^{2}\right)} \frac{t^{3}}{R}
$$

The above equation may be used as long as the corresponding compressive stress in the tube generated by $P_{C . r . E}$ is less than the proportional limit of the material.

$$
\sigma_{P . L .}>\sigma_{\operatorname{tmax}}=\frac{2 \times P_{C \cdot r . E}(O D)^{2}}{O D^{2}-I D^{2}}
$$

where:

$$
\sigma_{\text {tmax }}=\text { maximum tangential fiber stress. }
$$

Whenever the calculated value for $\sigma_{\text {tmax }}$ exceeds the elastic limit, the true critical pressure will be less than that obtained for "P ${ }_{\text {C.r.E. }}$. For those cases when the obtained $P_{\text {c.r.E }}$ produced " $\sigma_{\text {tmax }}$ " values exceeding the proportional limit, the following equations were utilized to calculate an external critical collapse pressure.

1) Assume that the fuel rods acquired an ellipticity $\left(u_{0}\right)=0.0051 \mathrm{~cm}(0.002$ in. $)$
(a) $P_{Y . P .}=\frac{\sigma_{Y . P .}\left[O D^{2}-1 D^{2}\right]}{2 \times O D^{2}}$ $P_{y \cdot p .}$

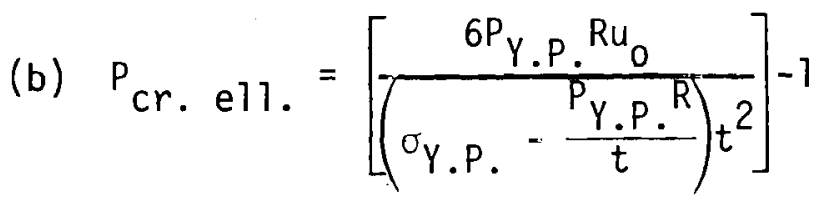


The critical pressure based on the modulus of elasticity $\left(P_{c r . E}\right)$ was first used to calculate an external collapsing pressure for the fuel rods. This would be the differential pressure (between the outside and inside of the clad) across the fuel rod wall. A 238.2 atm (3500 psi) differential collapse pressure was calculated as the critical pressure for the PWR fuel rod. This pressure was further checked to determine if it would produce a maximum tangential fiber stress $\left(\sigma_{\text {tmax }}\right)$ below the proportional limit, which it did.

$$
\sigma_{P . L .}>\frac{2(0 D)^{2} P_{C r . E}}{\left[0 D^{2}-I D^{2}\right]}
$$

or

$$
\sigma_{\text {P.L. }}>\frac{2(O D)^{2} E}{\left[O D^{2}-I D^{2}\right] 4\left(1-u^{2}\right)} \frac{t^{3}}{R}
$$

The calculations indicate a relatively high confidence level for a differential pressure near $238.2 \mathrm{~atm}(3500 \mathrm{psi})$ as being the critical collapse pressure for the PWR fuel rod.

It was further approximated that the internal gas pressure of the PWR fuel rod in an operating reactor is at 68 atm $(1000 \mathrm{ps} i)$ and $315.5^{\circ} \mathrm{C}\left(600^{\circ} \mathrm{F}\right)$. At the time the tube collapses it was assumed that the internal gas temperature was $37.8^{\circ} \mathrm{C}\left(100^{\circ} \mathrm{F}\right)$. A constant volume process $\mathrm{P}_{1} / \mathrm{T}_{1}=\mathrm{P}_{2} / \mathrm{T}_{2}=\mathrm{C}$ was used to determine that $36.1 \mathrm{~atm}$ (530 psi) is the approximate internal gas pressure of the PWR fuel rod at the time it collapses. By combining both pressures, $238.2 \mathrm{~atm}+36.1 \mathrm{~atm}=274.2 \mathrm{~atm}(3500 \mathrm{psi}+530 \mathrm{psi}=4030 \mathrm{psi})$, $274.2 \mathrm{~atm}$ (4030 psi) was the calculated pressure to collapse the PWR fuel rod. It is estimated that the PWR fuel rod would collapse at $2734 \mathrm{~m}(8970 \mathrm{ft}$ ) below sea level.

The BWR fuel rod is more complex to analyze. The external critical collapse pressure based on the modulus of elasticity $\left(P_{\mathrm{Cr} . E}\right)$ produced a maximum tangential fiber stress $\left(\sigma_{\text {tmax }}\right.$ ) which exceeded the proportional limit. On closer examination the clad thickness for the BWR rod is greater than is normally defined as truly a thin-walled cylinder, yet the clad does not quite react like a thick-walled cylinder. The approach used to approximate the 
collapse pressure of the BWR fuel rod is to first estimate an external pressure which would produce a maximum tangential fiber yield stress. The clad was considered to have an out-of-roundness of $0.0051 \mathrm{~cm}(0.002 \mathrm{in}$ ) (a value which has been substantiated through actual experience). A critical pressure based on tube ellipticity and external pressures producing fiber yield stresses was used to estimate a critical collapse pressure for the BWR fuel rod.

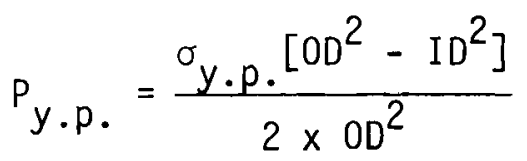

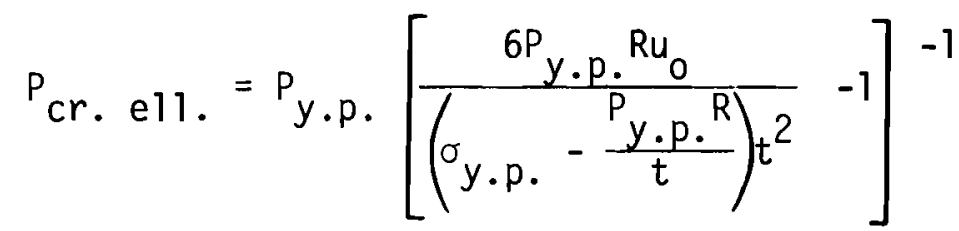

The above equations estimated that the differential collapse pressure for the BWR fuel rod is $306.2 \mathrm{~atm}$ (4500 psi). During reactor operation, the internal gas pressure is approximately $17 \mathrm{~atm}(250 \mathrm{psi})$ at $315.6^{\circ} \mathrm{C}\left(600^{\circ} \mathrm{F}\right)$. During rod failure, it is again assumed that the gas temperature is $37.8^{\circ} \mathrm{C}\left(100^{\circ} \mathrm{F}\right)$. By utilizing the equations for a constant volume process, the gas pressure during failure is estimated to be about $8.85 \mathrm{~atm}(130 \mathrm{psi})$.

By combining both pressures, it is estimated that the static ocean pressure which would collapse the BWR fuel rod is $315.1 \mathrm{~atm}$ (4630 psi). The equation derived for predicting ocean depth vs. ocean static pressure set the collapse of the BWR fuel tube at $3142 \mathrm{~m}(10,310 \mathrm{ft})$.

\section{A.4 FAILURE THRESHOLD OF SPENT FUEL CASK BY CORROSION}

If the fuel rods are not failed by a severe fire or lost to crushing ocean depths, corrosion becomes the primary failure mode. Corrosion when compared to fire-induced rupture of hydrostatic collapse is a very slow process. However, it will occur, albeit slowly, at all ocean depths.

Initial interchange of the sea water from the ocean and the interior of the cask will be 1 imited to small openings past the leaking seals. Concurrent corrosion attack on the outer stainless steel shell and shielding would expose the cask contents more directly to the marine environment after a long period of time. 
The mechanisms of corrosion in stainless steel exposed to sea water are very complex. Pitting and crevice types of corrosion would predominate as compared to carbon steels which generally tend toward uniform corrosion. Review of U.S. Naval Civil Engineering Laboratory immersion tests (1) of stainless steels in deep water $\sim 1524 \mathrm{~m}$ ( $\sim 5000 \mathrm{ft}$ ) indicate an overall corrosion rate for types 304 or 316 stainless steels would average approximately $0.08 \mathrm{~mm}$ ( 3 mils) per year. The mechanisms would be a combination of pitting and crevice corrosion. Combining the thickness of the inner and outer stainless steels in a typical spent fuel cask $5.1-6.35 \mathrm{~cm}(2-2-1 / 2 \mathrm{in}$.), the cask could be expected to provide some barrier against seawater intrusion for 650-850 years. During the period of resistance, the openings would enlarge to some extent and local attack might provide a several-fold increase in area for seawater intrusion. The corrosion rate above is based on the assumption that the stainless steel shell is very nearly at the ambient seawater temperature. The effects of elevated temperature are unknown.

The corrosion of the Zircaloy fuel clad does not depend on the prior corrosion of the stainless steel shel1. Leakage of sea water into the cask is expected even at continental shelf depths.

Corrosion of the Zircaloy fuel clad in the marine environment is difficult to predict because of an almost complete lack of test data. Zirconium and Zircaloys are exceptionally stable in sea water, exhibiting a corrosion resistance similar to titanium, but the resistance to corrosion can be markedly affected by impurities. (2) Zircaloys, such as Zircaloy-4 have superior corrosion resistance at elevated temperatures. Corrosion mechanisms leading to accelerated rates locally, such as pitting and crevice corrosion, may occur on the clad and should eventually be tested in a real or simulated marine environment.

Since data on zirconium are scarce, corrosion rates for the similar titanium are used. The NCEL tests $(1)$ found essentially no visible corrosion on specimens of titanium alloys. This would indicate a rate less than $2.5 \times 10^{-5} \mathrm{~mm}(0.001 \mathrm{mil})$ per year. Certain weld areas corroded at rates 
of approximately $2.5 \times 10^{-4}(0.01 \mathrm{mil})$ per year. Thus, corrosion might be expected to open very limited weld areas within 2000-3000 years. 0ther corrosion mechanisms could cause localized failures in less time. General wasting away of the material would not be expected for tens of thousands of years. 


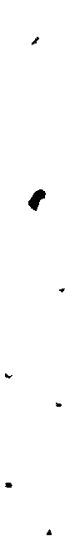

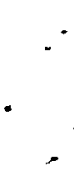

- 


\section{REFERENCES}

1. Reihart, F., Corrosion of Materials in Hydrospace, U. S. Naval Civil Engineering Laboratory, Technical Report R-504.

2. Butler, G., and H. C. K. Ison, "Corrosion and Its Prevention in Water", Reinhold Publishing Corporation, New York, NY, 1966. 
APPENDIX B

\section{PACKAGE BURIAL IN MARINE SEDIMENT}

The ocean floor generally has a covering of some depth of unconsolidated material. The depth may be a thousand feet in the deep oceans, a few feet on the continental shelf or hundreds of feet in alluvial deposits. This section considers the possibility and consequences of the burial of a free-falling shipping package in these sediments.

Given a suitable depth of sediment, there are two pre-conditions for selfburial of a shipping package. These are that the package fall free of the ship and that the package have sufficient negative buoyancy to allow it to generate a large momentum at impact. It is considered unlikely that a shipping package would be thrown from a ship considering the secure tie-down systems that would be used and the fact that the package may be carried in below deck storage. Only a free-falling spent fuel cask could generate sufficient momentum to bury itself in marine sediments. The possibility of burying a free-falling 6M package in sediments was not considered since the package would not have sufficient negative buoyancy to achieve the required impact velocity.

\section{B.1 POTENTIAL OF FREE-FALLING SPENT FUEL CASK FOR BURIAL}

During free fall, the forces acting on a free-falling cask consist of a gravitational force, a buoyant force, and a drag force. The impact velocity of the cask on the ocean floor can be determined from estimates of these forces. The derivation below assumes that the cask is a smooth-surfaced right circular cylinder. The surface projections such as cooling fins would tend to increase drag; thus the calculations are somewhat conservative. Assuming that the cask does not tumble during free-fall, the drag force is proportional to the square of the instantaneous velocity. 


$$
\begin{aligned}
& F_{\text {total }}=\text { weight }+ \text { buoyant force }+ \text { drag force } \\
& m \frac{d V}{d t}=m g-I R^{2} L \rho g-C_{D} A \frac{V^{2}}{2} \\
& m=\text { mass of cask }=72,640 \mathrm{~kg}(160,000 \mathrm{lb}) \\
& g=\text { acceleration of gravity }=9.81 \mathrm{~m} / \mathrm{s}^{2}\left(32 \mathrm{ft} / \mathrm{sec}^{2}\right) \\
& L=\text { cask length }=4.9 \mathrm{~m}(16 \mathrm{ft}) \\
& \rho=\text { density of sea water }=1030 \mathrm{~kg} / \mathrm{m}^{3}\left(\frac{641 \mathrm{~b}}{\mathrm{ft}^{3}}\right) \\
& R=\text { cask radius }=0.76 \mathrm{~m}(2.5 \mathrm{ft}) \\
& A=\text { cask cross sectiona } 1 \text { area normal to } \mathrm{flow} . \quad \Pi R^{2} \text { for axial } \\
& \quad \text { fall; } 2 R L \text { for side fal1 } \\
& V=\text { cask velocity } \mathrm{m} / \mathrm{sec} \\
& C_{D}=\text { Drag coefficient } 0.881 \text { for axial fall; } 0.355 \text { for side fall } 1 \\
& t=\text { time (sec) }
\end{aligned}
$$$$
\text { Equation (B.1) is of the form of Riccati's equation. (1) Assuming zero }
$$
initial velocity, the solution for velocity and fall distance as functions of time are:

$$
\begin{aligned}
& v=\frac{a_{1}}{a_{2}} \frac{\sinh \left(a_{1} a_{2} t\right)}{\cosh \left(a_{1} a_{2} t\right)} \\
& s=\frac{1}{a_{2}} \ln \left[\cosh \left(\sqrt{a_{1} a_{2}} t\right)\right] \\
& s=f a 11 \text { distance } \\
& a_{1}=g\left[1-\frac{A L \rho}{m}\right] \\
& a_{2}=\frac{C_{D \rho} A}{2 m}
\end{aligned}
$$

Solutions for equation (B.2) for both the axial and side fall configurations are shown in Figure B.1. 


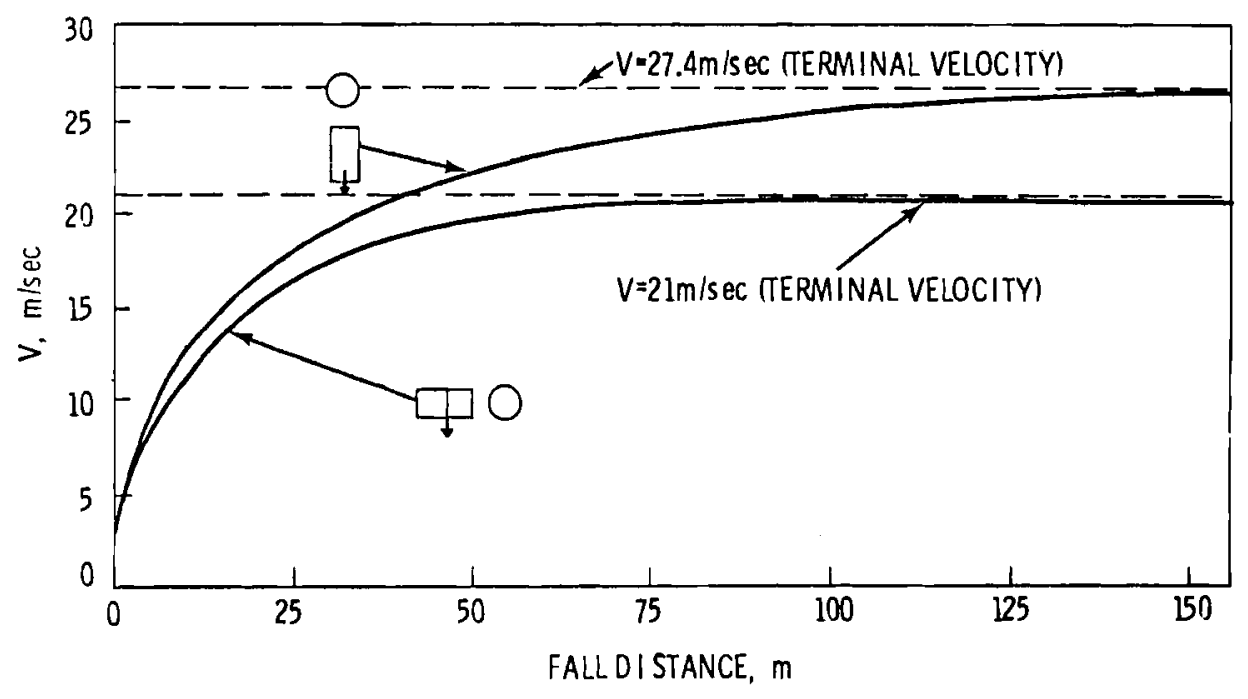

FIGURE B.1. Velocity vs Fall Distance $-72,640 \mathrm{~kg}$ $1.52 \mathrm{~m}$ Dia $\times 4.9 \mathrm{~m}$ (80 Ton - $5 \mathrm{ft} \times 16 \mathrm{ft}$ ) Cylinder in Sea Water

For the axial or end drop orientation, the terminal velocity is $27.5 \mathrm{~m} / \mathrm{sec}$ $(90.0 \mathrm{ft} / \mathrm{sec})$. This velocity is reached after a depth of about $122 \mathrm{~m}(400 \mathrm{ft})$. For the side fall orientation, the terminal velocity is $21 \mathrm{~m} / \mathrm{sec}(70 \mathrm{ft} / \mathrm{sec})$ which is reached at a depth of $61 \mathrm{~m}(200 \mathrm{ft})$.

Further detailed studies are required to establish the most likely cask orientation at impact. The side orientation is known to be the stable drop orientation for ideal cylinders for a wide range of conditions. However, for actual casks the location of the center of mass may differ from that of an ideal cylinder. Also, the cask design may have external structures which may function as fins or control surfaces and force the cask into an end-on orientation. While for specific casks the side orientation in free fall could be established by detailed studies, for conservatism an end-on orientation has been assumed in this analysis.

Burial depths were calculated for a range of representative marine sediments and for a limiting case of dry sand as well. Both the end and the side drop orientations were considered. The results for the range of sediment parameters and analytical assumptions show that a free fall to depths of a 
hundred meters will result in complete burial of a cask. The predicted burial depths range from about one cask diameter for a very firm media such as dry sand to over a hundred meters for very weak marine sediments.

The predictions of burial depths in marine sediments was based on the methodology and sediment characteristics given in Reference 2. Burial depth was based on the Poncelet penetration equation, which for soils takes the form

$$
\begin{aligned}
& m \frac{d V}{d t}=s N_{C} A_{F}-\delta_{a} s A_{s}-1 / 2 \rho C_{D} A_{F} V^{2} \\
& m=\text { mass of projectile } 72,640 \mathrm{~kg}(160,000 \text { 1b) } \\
& s=\text { dynamic sediment shear strength (from Reference 2) } \\
& t=\operatorname{time}(\mathrm{sec}) \\
& v=\text { velocity of projectile } \mathrm{m} / \mathrm{s} \text { with initial values of } 27.4 \mathrm{~m} / \mathrm{sec} \\
& (90 \mathrm{ft} / \mathrm{sec}) \text { for axial fall, } 21 \mathrm{~m} / \mathrm{sec}(70 \mathrm{ft} / \mathrm{sec}) \text { for side fall } \\
& N_{c} \text { = bearing capacicy factor (known function of soil friction } \\
& \text { angle) } \\
& \delta_{a}=\text { adhesion reduction factor } 0.2 \\
& A_{S}=\text { side area of projectile } 7.43 \mathrm{~m}^{2}\left(80 \mathrm{ft}^{2}\right) \\
& A_{F}=\text { frontal area of projectile }=1.82 \mathrm{~m}^{2}\left(19.6 \mathrm{ft}^{2}\right) \\
& \rho=\text { mass bulk density of sediment }=1700 \mathrm{~kg} / \mathrm{m}^{3}\left(106 \mathrm{lb} / \mathrm{ft}^{3}\right) \\
& C_{D}=\operatorname{drag} \text { coefficient }(0.88 \text { for axial fall, } 0.35 \text { for side fall) }
\end{aligned}
$$

In this equation, penetration resistance is expressed as a combination of static shear and inertial drag resistance. In the analysis, terms were added to account for forces due to the cask weight and buoyancy which evidently were not considered in Reference 2 . This equation was integrated numerically with a starting value of $V$ as the terminal velocity for free fall in water.

A sediment density of $1700 \mathrm{~kg} / \mathrm{m}^{3}\left(106 \mathrm{lb} / \mathrm{ft}^{3}\right)$ was assumed. Dynamic shear strength values for sediments were taken from Reference 2 . Precise values of bearing capacity factor $\left(\mathrm{N}_{\mathrm{C}}\right)$ were difficult to define. However, data in References 3 and 4 indicate that for the weak sediments of primary interest here 
the soil friction angle should not exceed 20 degrees. This bounds $\left(N_{C}\right)$ to be in the range of 5.7 to about 25 . Analyses were performed for these limiting values of $\mathrm{N}_{\mathrm{C}}$.

Table B.1 gives predicted burial depths for a range of marine sediments. The analyses accounted for variations in sediment properties with depth as given in Reference 2 . The greatest burial depths are predicted for the end drop condition in the weaker sediments.

TABLE B.1. Estimated Burial Depths in Representative Marine Sediments for a 73-MT Cylinder with a $1.5 \mathrm{~m}$ Diameter and a $4.9 \mathrm{~m}$ Length

\begin{tabular}{|c|c|c|}
\hline Sediment Type & $\begin{array}{c}\text { Depth of Cask } \\
\text { End Drop } \\
\end{array}$ & $\begin{array}{l}\text { Penetration } \\
\text { Side Drop } \\
\end{array}$ \\
\hline $\begin{array}{l}\text { Very Weak Sediment } \\
\text { Mississippi Delta }\end{array}$ & $\begin{array}{l}82-146 \mathrm{~m} \\
(270-480 \mathrm{ft})\end{array}$ & $\begin{array}{l}24-76 \mathrm{~m} \\
(80-250 \mathrm{ft})\end{array}$ \\
\hline $\begin{array}{l}\text { Typical Normally Consolidated } \\
\text { Cohesive Marine Sediment-130th } \\
\text { Pelogic and Terrigenous }\end{array}$ & $\begin{array}{l}15-30 \mathrm{~m} \\
(50-100 \mathrm{ft})\end{array}$ & $\begin{array}{l}4.6-14 \mathrm{~m} \\
(15-45 \mathrm{ft})\end{array}$ \\
\hline $\begin{array}{l}\text { California Continental } \\
\text { Borderland }\end{array}$ & $\begin{array}{l}11-21 \mathrm{~m} \\
(35-70 \mathrm{ft})\end{array}$ & $\begin{array}{l}3.0-9.1 \mathrm{~m} \\
(10-30 \mathrm{ft})\end{array}$ \\
\hline
\end{tabular}

Notes: 1. Impact speed for side drop $21 \mathrm{~m} / \mathrm{sec}$ attaining terminal velocity at a depth of about $61 \mathrm{~m}$.

2. Impact speed for end drop $27.4 \mathrm{~m} / \mathrm{sec}$ attaining terminal velocity at a depth of about $122 \mathrm{~m}$.

3. Range of cask penetration depths corresponds to values of $\mathrm{Nc}=5.7$ to 25 .

However, even for a side drop onto the most firm of the sediments considered, the predicted burial depth is greater than one diameter for the most conservative value of $\mathrm{N}_{\mathrm{C}}$.

In an independent evaluation, penetration data for spherical projectiles into dry sand were applied. This media can be considered as an upper limit for penetration resistance for marine sediments. In the analyses the cylinder parameters were used to define a sphere of equivalent mass and frontal area. Predicted penetration depths were $4.3 \mathrm{~m}(14 \mathrm{ft})$ for the end impact condition 
and $1.5 \mathrm{~m}(5 \mathrm{ft})$ for the side impact condition. These predictions are based in curves given in Reference 5 , which summarizes test data from various sources.

\section{B.2 THERMAL CONSIDERATIONS OF BURIAL OF SPENT FUEL CASK}

From the results of Section B.1.2, it is apparent that if the conditions of a free faliing cask, sufficient fali distance and adequate sediment depth are met, a falling cask will be buried in sediment to a depth of at least several cask diameters. In this state, it is uniikely that a significant surface area of the cask will be exposed directly to sea water. This precludes heat removal by free convection. It is feit therefore that heat removal will occur primarily by vaporization of sea water and to a lesser degree by conduction through the sediments.

Approximate quantitative information regarding the conduction and vaporization modes of heat removal was obtained for the following set of conditions:

$$
\begin{aligned}
Q= & \text { total heat rate of cask }=90 \mathrm{~kW}=\left(307,350 \frac{\mathrm{Btu}}{\mathrm{hr}}\right) \\
\mathrm{h}= & \text { depth of cask below sea leve }=200 \text { meters, }(656 \mathrm{ft}) \\
\mathrm{L}= & \text { cask length }=4.9 \mathrm{~m}(16 \mathrm{ft}) \\
\mathrm{D}= & \text { cask diameter }=1.5 \mathrm{~m}(5 \mathrm{ft}) \\
\mathrm{K}= & \text { sediment conductivity }=1.34 \mathrm{~W}^{2} \mathrm{~m}^{2}{ }^{\circ} \mathrm{K}\left(0.237 \frac{\mathrm{Btu}}{\mathrm{hr} \mathrm{ft}^{\circ} \mathrm{F}}\right) \text { Reference } 6 \\
\mathrm{~h}_{\mathrm{fg}}= & \text { heat of vaporization of sea water a a depth of } 200 \text { meters } \\
\quad=448 \mathrm{~kg} \text { cal } / \mathrm{kg}(806 \mathrm{Btu} / 1 \mathrm{bm}) & \\
T \mathrm{TW}= & \text { ambient water temperature }=4^{\circ} \mathrm{C}\left(40^{\circ} \mathrm{F}\right) \\
& \text { Tc: Outer wa } 11 \text { cask temperature }
\end{aligned}
$$

For a horizontal cask buried at least several diameters deep, the steady state heat removal rate by conduction has been approximated by the following equations from Reference 7.

$$
\begin{aligned}
& q=\frac{2 \pi K L}{\ln \left(L^{2} / D\right)}(T C-T w) \\
& q=1.952 \mathrm{~kW}\left(6661 \frac{\mathrm{Btu}}{\mathrm{HR}}\right)
\end{aligned}
$$




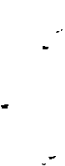


This is only about two percent of the presumed heat load. However, it should be emphasized that initial heat transfer rates (before the surrounding sediment becomes heated) could be considerably greater than this steady state value.

Heat removal by vaporization of sea water must be based upon the assumption that transport of sea water to the cask surface is possible. The amount of coolant required can be determined from the cask heat load and the heat of vaporation of water at the cask depth (200 meters).

$$
\begin{aligned}
\text { coolant flowrate } & =\frac{90 \mathrm{~kW}}{448 \mathrm{~kg} \mathrm{cal} / \mathrm{kg}}=\frac{77,400 \mathrm{cal} / \mathrm{hr}}{448 \mathrm{~kg} \mathrm{cal} / \mathrm{kg}} \\
& =173 \frac{\mathrm{kg}}{\mathrm{hr}}=168 \frac{\ell}{\mathrm{hr}}\left(5.9 \frac{\mathrm{ft}^{3}}{\mathrm{hr}}\right)
\end{aligned}
$$

Immediately after impact, transport of water to the cask surface would be available through the entrance path formed by the cask. If this path becomes blocked, then seepage through the sediment would provide the only supply of water. This seepage rate in turn would depend on sediment permeability and the amount of seepage retardation caused by vapor pressure buildup in the cask vicinity. It seems likely that for tightly packed clay-like sediment, cask temperatures would eventually become excessive.

In summary, if the thermal conductivity of the sediments is low, sufficient heat could not be removed by this mechanism. Heat removed would depend on seepage of water through the sediments to the cask. If the diffusion of water was too slow, sufficient heat could not be removed by either mechanism. This would result in high temperatures which could fail both the cask and the fuel pins. 


\section{REFERENCES}

1. Cunningham, W. J., Introduction to Nonlinear Ana lyses, McGraw-Hil1 Book Company, New York, NY, 1958.

2. Schneider, K. J., and A. M. Platt, (editors), "High-level Radioactive Waste Management A1ternatives - Volume 3", BNWL-1900, Battelle, Pacific Northwest Laboratories, Richland, WA, May 1974.

3. Sowers, G. B., and G. F. Sowers, Introductory Soil Mechanics and Foundations, 3rd edition, MacMillan, New York, NY, 1970.

4. Zeevaert, "Foundation Engineering for Difficult Subsoil Conditions", Van Nostrand Reinhold, New York, NY, 1973.

5. Kornhauser, M., Structural Effects of Impact, Spartan, Baltimore, MD, 1964.

6. Shepard, F. P., Submarine Geology, 2nd edition, Harper and Row, publishers, New York, NY, 1963.

7. Rohsenow, W. M., and J. P. Hartnett, Handbook of Heat Transfer, McGrawHil1, New York, NY, 1973. 
APPENDIX C

\section{RADIOACTIVE MATERIAL RELEASE}

\section{1 RELEASE QUANTITIES FROM PLUTONIUM SHIPPING PACKAGE}

For the plutonium shipping package there is only one release mode and it is assumed that the entire contents are released during the first year. Two loadings for the package have been considered. The first is a low burnup case containing $4.5 \mathrm{~kg}$ of $\mathrm{PuO}_{2}$. The plutonium isotopic mixtures are $95 \mathrm{wt} \%{ }^{239} \mathrm{Pu}$ and $5 \mathrm{wt} \%{ }^{240} \mathrm{Pu}$. The second loading is typical recycle plutonium having $1.5 w t \%{ }^{238} \mathrm{Pu}, 58 w t \%{ }^{239} \mathrm{Pu}, 24 w t \%{ }^{240} \mathrm{Pu}, 11 \mathrm{wt} \%{ }^{241} \mathrm{Pu}, 4.9 \mathrm{wt} \%{ }^{242} \mathrm{Pu}$ and $1.0 \mathrm{wt} \%{ }^{241} \mathrm{Am}$. Because of the heat generation of this higher burnup plutonium, only $2.55 \mathrm{~kg} \mathrm{Pu}$ is allowed in a single package. Table C.1 gives the weight and curies released for each loading.

\section{C.2 RELEASE QUANTITIES FROM SPENT FUEL CASK}

The radioactive isotopes considered in this analysis are listed in Table C.2. As detailed in Section 6.2.1, the radioactive releases from immediate failure have been divided into two release modes. These are the volatile releases from diffusion (in-reactor and fire) and those releases from leaching of the $\mathrm{UO}_{2}$ fuel by sea water. Table C. 3 gives each of these release quantities plus the total of these two which represents the total radioactive releases as a result of immediate failure by fire. Table C. 4 gives the leaching releases (for immediate failure) calculated at various time periods and then numerically summed to get a total integrated release.

The radioactive releases from the 1000-year delayed failure have been divided into three release segments. The releases from $99 \%$ of the fuel rods failing after 1000 years and the volatile and leaching releases from $1 \%$ of the fuel rods which were failed prior to the loss of the cask at sea. Each of these release quantities are given in Table C.5, plus the total of the three, which represents the total radioactive releases as a result of a delayed failure (non-pressure resistant cask) on the continental shelf. The case of delayed cask failure (pressure resistant cask) can be taken from 
tne delayed failure column of Table C.5 which assumes immediate cask failure. The semi-volatile and cesium leaching releases (discussed in Section 6.2.2) are also given individually in Tables C.6 and C.7, respectively.

TABLE C.1. Plutonium Release Quantities

\begin{tabular}{|c|c|c|c|}
\hline Loading & Isotope & Weight (grams) & Curies \\
\hline $4.5 \mathrm{~kg} \mathrm{PuO} 2$ & ${ }^{239} \mathrm{Pu}$ & 3770 & 232 \\
\hline Low Burnup & ${ }^{240} \mathrm{Pu}$ & 198 & 43 \\
\hline $2.55 \mathrm{~kg} \mathrm{Pu}$ & ${ }^{238} \mathrm{Pu}$ & 38 & 647 \\
\hline Typical Recycle & ${ }^{239} \mathrm{Pu}$ & 1479 & 91 \\
\hline & ${ }^{240} \mathrm{Pu}$ & 612 & 134 \\
\hline & ${ }^{241} \mathrm{Pu}$ & 281 & 28,160 \\
\hline & ${ }^{242} \mathrm{Pu}$ & 125 & 0.5 \\
\hline & ${ }^{241} \mathrm{Am}$ & 25 & 86 \\
\hline
\end{tabular}

TABLE C.2. Radioactive Isotopes Considered in This Study

\begin{tabular}{|c|c|c|c|c|}
\hline $3_{H}$ & $110 m_{A g}$ & ${ }^{136} \mathrm{Cs}$ & ${ }^{156} \mathrm{Eu}$ & ${ }^{239} \mathrm{Pu}$ \\
\hline${ }^{79} \mathrm{Se}$ & ${ }^{123} \mathrm{Sn}$ & ${ }^{137} \mathrm{Cs}$ & ${ }^{160} \mathrm{~Tb}$ & ${ }^{240} \mathrm{Pu}$ \\
\hline $85_{\mathrm{Kr}}$ & ${ }^{126} \mathrm{Sn}$ & $140_{\mathrm{Ba}}$ & $166 \mathrm{~m}_{\mathrm{HO}}$ & $241 \mathrm{Pu}$ \\
\hline${ }^{87} \mathrm{Rb}$ & ${ }^{124}{ }_{S b}$ & $140_{\mathrm{La}}$ & ${ }^{233} \mathrm{~Pa}$ & ${ }^{242} \mathrm{Pu}$ \\
\hline${ }^{89} \mathrm{Sr}$ & ${ }^{125} \mathrm{Sb}$ & ${ }^{144} \mathrm{Ce}$ & $232_{U}$ & $241_{\mathrm{Am}}$ \\
\hline${ }^{90} \mathrm{Sr}$ & ${ }^{126}{ }_{S b}$ & ${ }^{143} \mathrm{Pr}$ & $233_{U}$ & ${ }^{242 m_{A n}}$ \\
\hline $90_{\gamma}$ & $125 \mathrm{~m}_{\mathrm{Te}}$ & ${ }^{144} \mathrm{Pr}$ & $234_{U}$ & ${ }^{243} \mathrm{Am}$ \\
\hline $91_{Y}$ & $127 \mathrm{~m}_{\mathrm{T} \epsilon}$ & $147_{\mathrm{Nd}}$ & $235_{U}$ & ${ }^{242} \mathrm{~cm}$ \\
\hline${ }^{93} \mathrm{Zr}$ & ${ }^{127} \mathrm{Te}$ & ${ }^{147} \mathrm{Pm}$ & $236_{U}$ & ${ }^{243} \mathrm{Cm}$ \\
\hline $93 m_{N b}$ & $129 \mathrm{~m}_{\mathrm{Te}}$ & $148 m_{\mathrm{Pm}}$ & $237_{U}$ & ${ }^{244} \mathrm{Cm}$ \\
\hline${ }^{95} \mathrm{Nb}$ & ${ }^{129} \mathrm{Te}$ & ${ }^{148} 8_{\mathrm{Pm}}$ & $238_{U}$ & ${ }^{245} \mathrm{Cm}$ \\
\hline${ }^{99} \mathrm{TC}$ & ${ }^{129} \mathrm{I}$ & ${ }^{152} \mathrm{Eu}$ & ${ }^{237} \mathrm{~Np}$ & ${ }^{246} \mathrm{~cm}$ \\
\hline${ }^{103} \mathrm{Ru}$ & ${ }^{134} \mathrm{Cs}$ & $154_{\mathrm{Eu}}$ & ${ }^{239} \mathrm{~Np}$ & ${ }^{247} \mathrm{Cm}$ \\
\hline$S_{B u}$ & ${ }^{135} \mathrm{Cs}$ & ${ }^{155_{E u}}$ & ${ }^{238} \mathrm{Pu}$ & ${ }^{0}$ \\
\hline
\end{tabular}


TABLE C.3. Total Curies Released from Severe Fire

\begin{tabular}{|c|c|c|c|}
\hline Isotope & $\begin{array}{c}\text { Semi-Volatile Release } \\
\text { from Diffusion } \\
\text { (in-reactor }+ \text { fire) } \\
\end{array}$ & $\begin{array}{l}\text { Release by } \mathrm{UO}_{2} \\
\text { Leaching } \\
\text { with Sed Water } \\
\end{array}$ & $\begin{array}{c}\text { Total } \\
\text { (curies) }\end{array}$ \\
\hline $3_{H}$ & $1.57 \times 10^{3}$ & -- & $1.57 \times 10^{3}$ \\
\hline${ }^{79} \mathrm{Se}$ & 0.13 & 1.24 & 1.37 \\
\hline${ }^{87} \mathrm{Rb}$ & $9 \times 10^{-6}$ & $6.1 \times 10^{-5}$ & $7.04 \times 10^{-5}$ \\
\hline${ }^{89} \mathrm{Sr}$ & $3.02 \times 10^{3}$ & 319 & $3.33 \times 10^{3}$ \\
\hline${ }^{90} \mathrm{Sr}$ & $2.4 \times 10^{3}$ & $3.59 \times 10^{4}$ & $3.84 \times 10^{4}$ \\
\hline $90_{Y}$ & -- & $3.59 \times 10^{4}$ & $3.59 \times 10^{4}$ \\
\hline${ }^{91}{ }_{Y}$ & -. & 784 & $7.84 \times 10^{2}$ \\
\hline${ }^{93} \mathrm{Zr}$ & -- & 5.90 & 5.90 \\
\hline $93 m_{\mathrm{Nb}}$ & -- & 5.33 & 5.33 \\
\hline${ }^{95} \mathrm{Zr}$ & -- & $8.35 \times 10^{3}$ & $8.35 \times 10^{3}$ \\
\hline${ }^{95} \mathrm{Nb}$ & -- & $1.62 \times 10^{4}$ & $1.62 \times 10^{4}$ \\
\hline${ }^{99}$ ic & -- & 44.3 & 44.3 \\
\hline${ }^{103_{\mathrm{Ru}}}$ & -. & $2.21 \times 10^{3}$ & $2.21 \times 10^{3}$ \\
\hline${ }^{106} \mathrm{Ru}$ & -- & $6.63 \times 10^{4}$ & $6.63 \times 10^{4}$ \\
\hline${ }^{107} \mathrm{Pd}$ & -- & 0.35 & $3.50 \times 10^{-1}$ \\
\hline $110 \mathrm{~m}_{\mathrm{Ag}}$ & -. & 32.6 & $3.26 \times 10^{1}$ \\
\hline${ }^{124} \mathrm{Sb}$ & 26.4 & 2.5 & 28.9 \\
\hline${ }^{125} \mathrm{Sb}$ & $2.48 \times 10^{3}$ & $1.89 \times 10^{3}$ & $4.37 \times 10^{3}$ \\
\hline${ }^{126} \mathrm{Sb}$ & 0.2 & 1.69 & 1.89 \\
\hline${ }^{126} \mathrm{Sn}$ & -. & 1.70 & 1.70 \\
\hline $125 \mathrm{~m}_{\mathrm{Te}}$ & 998 & 781 & $1.78 \times 10^{3}$ \\
\hline${ }^{127} \mathrm{Te}$ & $1.88 \times 10^{3}$ & 318 & $2.20 \times 10^{3}$ \\
\hline $127 \mathrm{~m}_{\mathrm{Te}}$ & $1.91 \times 10^{3}$ & 321 & $2.23 \times 10^{3}$ \\
\hline${ }^{129} \mathrm{Te}$ & $1.30 \times 10^{3}$ & 108 & $1.41 \times 10^{3}$ \\
\hline${ }^{129 m} \mathrm{Te}$ & $2.03 \times 10^{3}$ & 169 & $2.20 \times 10^{3}$ \\
\hline${ }^{129}$ I & 0.073 & 0.116 & $1.89 \times 10^{-7}$ \\
\hline${ }^{134} \mathrm{Cs}$ & $5.93 \times 10^{5}$ & $5.23 \times 10^{3}$ & $5.98 \times 10^{5}$ \\
\hline${ }^{135} \mathrm{Cs}$ & 0.79 & 0.098 & $8.88 \times 10^{-1}$ \\
\hline${ }^{136} \mathrm{cs}$ & 56.56 & 0.51 & 57.1 \\
\hline${ }^{137} \mathrm{Cs}$ & $2.95 \times 10^{5}$ & $6.09 \times 10^{3}$ & $3.01 \times 10^{5}$ \\
\hline $140 \mathrm{Ba}$ & 13.4 & 10.6 & 24.0 \\
\hline${ }^{140} \mathrm{La}$ & $\cdots$ & 12.2 & 12.2 \\
\hline${ }^{141} \mathrm{Ce}$ & -. & $1.40 \times 10^{3}$ & $1.40 \times 10^{3}$ \\
\hline${ }^{144} \mathrm{Ce}$ & -- & $1.05 \times 10^{3}$ & $1.05 \times 10^{5}$ \\
\hline $144 \mathrm{Pr}$ & -- & $1.05 \times 10^{3}$ & $1.05 \times 10^{5}$ \\
\hline${ }^{147} \mathrm{Nd}$ & - & 1.25 & 1.25 \\
\hline${ }^{147} \mathrm{Pm}$ & .. & $2.27 \times 10^{4}$ & $2.27 \times 10^{4}$ \\
\hline $148 m_{\mathrm{Pm}}$ & -- & 10.1 & 10.1 \\
\hline $148 \mathrm{Pm}$ & - & 0.79 & 0.79 \\
\hline${ }^{152} \mathrm{Eu}$ & -- & 3.91 & 3.91 \\
\hline $154 \mathrm{Eu}$ & -- & $2.46 \times 10^{3}$ & $2.46 \times 10^{3}$ \\
\hline $155_{\mathrm{EU}}$ & -- & $1.33 \times 10^{3}$ & $1.33 \times 10^{3}$ \\
\hline${ }^{156} \mathrm{Eu}$ & -- & 5.39 & 5.39 \\
\hline $160_{\mathrm{Tb}}$ &.- & 10 & 10 \\
\hline $238_{\mathrm{pu}}$ & - & $3.39 \times 10^{3}$ & $3.39 \times 10^{3}$ \\
\hline${ }^{239} \mathrm{Pu}$ & -- & $1.02 \times 10^{3}$ & $1.02 \times 10^{3}$ \\
\hline${ }^{240} \mathrm{Pu}$ & - & $1.48 \times 10^{3}$ & $1.48 \times 10^{3}$ \\
\hline${ }^{241} \mathrm{Pu}$ & -- & $3.27 \times 10^{4}$ & $3.27 \times 10^{4}$ \\
\hline${ }^{242} \mathrm{Pu}$ & -. & 4.31 & 4.31 \\
\hline${ }^{241}{ }_{\mathrm{Am}}$ & -- & $8.54 \times 10^{3}$ & $8.54 \times 10^{3}$ \\
\hline${ }^{242 m_{A m}}$ & -- & 14.94 & 14.94 \\
\hline $243_{\mathrm{Am}}$ & - & 56.6 & 56.6 \\
\hline${ }^{242} \mathrm{~cm}$ & -- & $1.05 \times 10^{3}$ & $1.05 \times 10^{3}$ \\
\hline${ }^{243} \mathrm{~cm}$ & -- & 1.53 & 1.53 \\
\hline${ }^{244} \mathrm{Cm}$ & -. & 877 & 877 \\
\hline${ }^{245} \mathrm{Cm}$ & -. & 1.11 & 1.11 \\
\hline${ }^{246} \mathrm{Cm}$ & -- & 0.22 & 0.22 \\
\hline${ }^{247} \mathrm{Cm}$ & -- & -. & -- \\
\hline${ }^{232} \mathrm{U}$ & -- & 0.014 & 0.014 \\
\hline $233_{U}$ & -- & -- & .. \\
\hline $234 \mathrm{U}$ & .. & 4.67 & 4.67 \\
\hline $235 \mathrm{U}$ & -. & -- & -- \\
\hline $236 u$ & -- & 0.90 & 0.90 \\
\hline $237_{U}$ & -- & 0.82 & 0.82 \\
\hline $238_{U}$ & -- & 0.97 & 0.97 \\
\hline${ }^{23} \mathrm{~Pa}_{\mathrm{Pa}}$ & -- & 1.63 & 1.63 \\
\hline${ }^{237} \mathrm{NP}$ & $\cdots$ & 1.63 & 1.63 \\
\hline${ }^{239} \mathrm{~Np}$ & -- & 56.6 & 56.6 \\
\hline
\end{tabular}


TABLE C.4. Leaching Releases after Immediate Failure by Fire - Curies

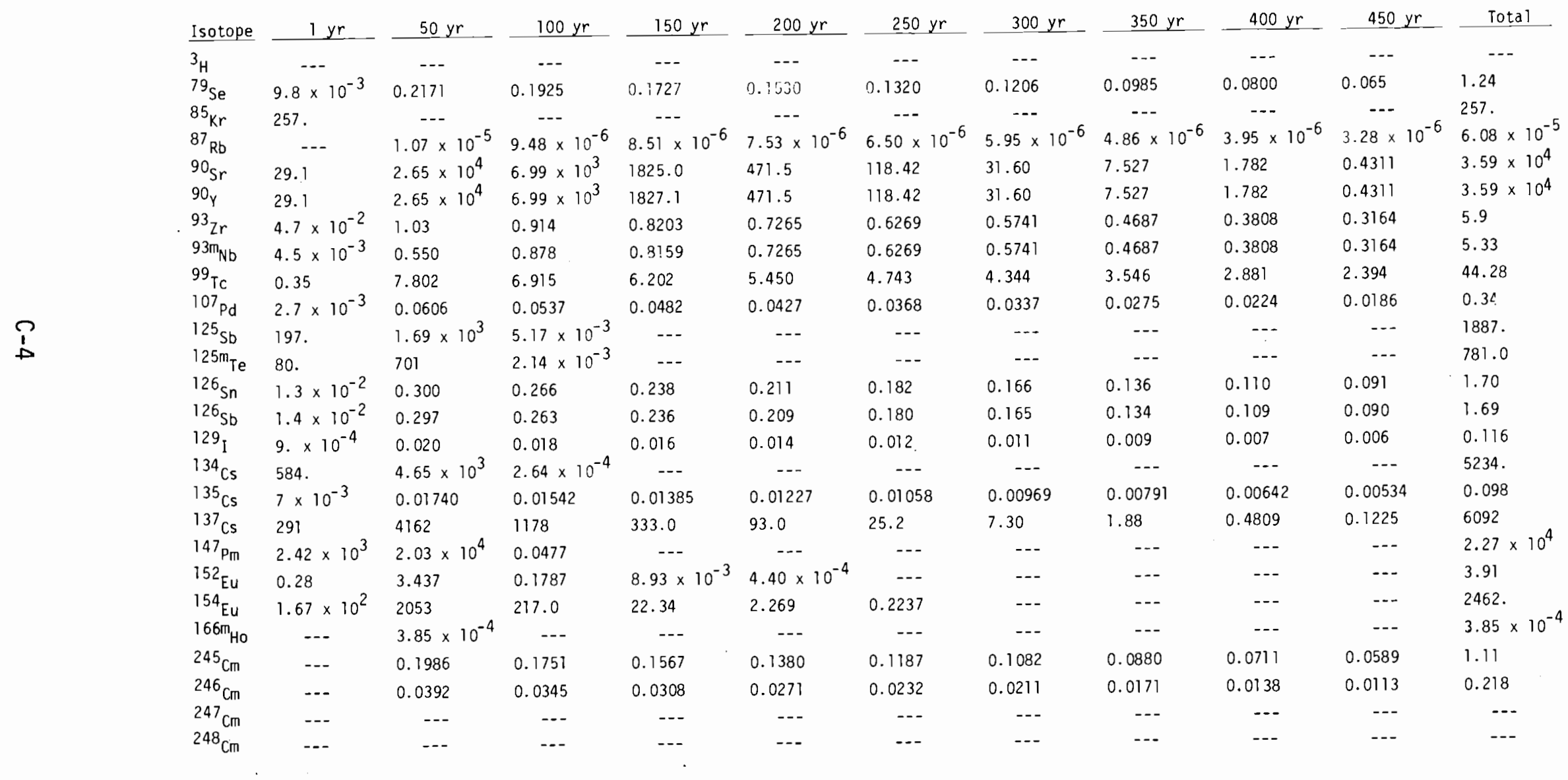




\section{TABLE C.4. Leaching Releases after Immediate Failure by Fire - Curies (cont'd)}

\begin{tabular}{|c|c|c|c|c|c|c|c|c|c|c|c|}
\hline Isotope. & $1 \mathrm{yr}$ & $50 \mathrm{yr}$ & $100 \mathrm{yr}$ & $150 \mathrm{yr}$ & $200 \mathrm{yr}$ & $250 \mathrm{yr}$ & $300 \mathrm{yr}$ & $350 \mathrm{yr}$ & $400 \mathrm{yr}$ & $450 \mathrm{yr}$ & Total \\
\hline${ }^{89} \mathrm{Sr}$ & 114. & 204.5 & -.. & $\cdots$ & $\cdots$ & $-\cdot$ & -.- & --- & $\ldots$ & --- & 319. \\
\hline $911_{\gamma}$ & 189. & 594.7 & --- & $\ldots$ & $\ldots$ & -.. & $\ldots$ & --- & ... & -.. & 784. \\
\hline${ }^{95} \mathrm{zr}$ & 6817. & 1541.3 & ... & ... & ... & ... & ... & ... & ... & --- & 8352. \\
\hline $95 \mathrm{Nb}$ & $1.28 \times 10^{4}$ & 3410.0 & -.. & -.. & -.- & -.. & -.- & $\ldots-$ & --- &.-- & $1.62 \times 10^{4}$ \\
\hline${ }^{103} \mathrm{Ru}$ & 2173. & 40.37 & -- & $\cdots$ & -.- & --- & -.. & -- & --- & -- & 2214. \\
\hline${ }^{106} \mathrm{Ru}$ & $1.01 \times 10^{4}$ & $56.2 \times 10^{3}$ & -.- & --- & -- & $\ldots$ & $\ldots$ & --- & --- & --- & $6.6 \times 10^{4}$ \\
\hline $110 \mathrm{~m}_{\mathrm{Ag}}$ & 6.4 & 26.22 & -.- & --- &.-- & ... & -.. & --- & -.- & -- & 32.6 \\
\hline $124_{5 b}$ & 2.2 & 0.3437 & -.- & ... & ..- & -.. & ... & ... & -.- & ... & 2.5 \\
\hline $127 \mathrm{~m}_{\mathrm{Te}}$ & 156.8 & 164.5 & -.- & -.- & ... & $\ldots$ & -.. & ..- & $\therefore$ & $\ldots$ & 321. \\
\hline${ }^{127} \mathrm{Te}$ & 155.1 & 162.59 & $\ldots$ & -- & --- & -.. & --- & $\ldots$ & --- & -- & 318. \\
\hline${ }^{129 \mathrm{~m}_{\mathrm{Te}}}$ & 167.6 & 1.048 & -.- & -.. & ... & $\ldots$ & -.- & ... & ..- & ... & 169. \\
\hline${ }^{129} \mathrm{Te}$ & 107.3 & 0.6711 & $\cdots$ & $\ldots$ &.-- & $\cdots$ & --- & $\ldots$ & ... & -- & 108. \\
\hline $136 \mathrm{cs}$ & 0.51 & -.. & $\cdots$ & -- &.-- & $\ldots$ &.- & -- & -.. & $\ldots$ & 0.51 \\
\hline${ }^{140} \mathrm{Ba}$ & 10.6 & ... & ... & -.- & -.. & $\ldots$ & -.. & $\ldots$ & -.. & ... & 10.6 \\
\hline $140_{\text {La }}$ & 12.2 & --- & -.. & ... & $\ldots$ & --- & -.. & $\ldots$ & $\ldots$ &.-- & 12.2 \\
\hline${ }^{141} \mathrm{Ce}$ & $1.40 \times 10^{3}$ & -.- & --- &.-- & -.. & -.. & -.. & -.- & -.- &.-- & $1.40 \times 10^{3}$ \\
\hline${ }^{144} \mathrm{Ce}$ & $1.90 \times 10^{4}$ & $86.2 \times 10^{4}$ & -.- & --. & ... & ... & -.. & ... & ... & -.- & $1.05 \times 10^{5}$ \\
\hline $144 \mathrm{pr}$ & $1.90 \times 10^{4}$ & $86.2 \times 10^{4}$ &.-- & $\ldots$ & -- & $\cdots$ & $\cdots$ & $\ldots$ & $\ldots$ & -- & $1.05 \times 10^{5}$ \\
\hline${ }^{147} \mathrm{Nd}$ & 1.25 & --- & $\ldots$ & -- & $\ldots$ & -- & $\ldots$ & -- & $\ldots$ & -- & 1.25 \\
\hline${ }^{14} 48_{P_{m}}$ & 0.79 & .. & $\ldots$ & $\ldots$ & -.- & -.- & -.- & ... & ... & ... & 0,79 \\
\hline $148 \mathrm{~m}_{\mathrm{P}_{\mathrm{m}}}$ & 9.8 & 0.2619 & -.. &.-- & --- & -.. & $\cdots$ & $\ldots$ & $\ldots$ & $\cdots$ & 10.1 \\
\hline${ }^{155} \mathrm{Eu}$ & 155.5 & 1175.8 & --- & $\ldots$ & -- & $\ldots$ & --- & -- & --- & $\ldots$ & $1.33 \times 10^{3}$ \\
\hline${ }^{156_{\mathrm{Eu}}}$ & 5.39 & -.- & -.- & ... & ..- & $\ldots$ & $\ldots$ & ..- & -.- & $\ldots$ & 5.39 \\
\hline${ }^{160} \mathrm{~Tb}$ & 7.5 & 2.5 & ... & --- & -.- & $\ldots$ & -.- & -.- & -.- & ..- & 10. \\
\hline $233_{\mathrm{Pa}}$ & $8.4 \times 10^{-3}$ & 0.2084 & 0.2104 & 0.2109 & 0.2049 & 0.1911 & 0.1871 & 0.1619 & 0.1384 & 0.1204 & 1.634 \\
\hline $232 u$ & $2 \times 10^{-4}$ & $6.93 \times 10^{-3}$ & $3.79 \times 10^{-3}$ & $1.86 \times 10^{-3}$ & $9.91 \times 10^{-4}$ & -.- & -.- & ... & -.- & ... & 0.014 \\
\hline
\end{tabular}


TABLE C.4. Leaching Releases after Immediate Failure by Fire - Curies (cont'd)

\begin{tabular}{|c|c|c|c|c|c|c|c|c|c|c|c|}
\hline Isotope & $1 \mathrm{yr}$ & $50 \mathrm{yr}$ & $100 \mathrm{yr}$ & $\therefore 150 \mathrm{yr}$ & $200 \mathrm{yr}$ & $250 \mathrm{yr}$ & $300 \mathrm{yr}$ & $350 \mathrm{yr}$ & $400 \mathrm{yr}$ & $450 \mathrm{yr}$ & Total \\
\hline $233 \mathrm{U}$ & $\ldots$ & $6.66 \times 10^{-5}$ & --- & -- & --- & --- & -- &.- & --- & -- & $6.66 \times 10^{-5}$ \\
\hline $234_{U}$ & $1.9 \times 10^{-2}$ & 0.5947 & 0.6432 & 0.6467 & 0.6150 & 0.5539 & 0.5225 & 0.4365 & 0.3587 & 0.2996 & 4.671 \\
\hline $235 \mathrm{U}$ & .. & $\cdots$ & -- & ... &.-- & --- & $\ldots$ & --- & --- & --- & -- \\
\hline $236_{U}$ & $7.1 \times 10^{-3}$ & 0.1577 & 0.1402 & 0.1263 & 0.1119 & 0.0969 & 0.0890 & 0.0729 & 0.0592 & 0.0494 & 0.904 \\
\hline $237 \mathrm{U}$ & $6.7 \times 10^{-2}$ & 0.7477 & 0.0665 & 0.0057 & -- & -- & -- & --- & -- & $\cdots$ & 0.82 \\
\hline $238 \mathrm{U}$ & $7.8 \times 10^{-3}$ & 0.1713 & 0.1519 & 0.1363 & 0.1207 & 0.1042 & 0.0954 & 0.0779 & 0.0633 & 0.0526 & 0.974 \\
\hline $237 \mathrm{~Np}$ & $3.4 \times 10^{-3}$ & 0.2084 & 0.2104 & 0.2109 & 0.2049 & 0.1911 & 0.1871 & 0.1619 & 0.1384 & 0.1204 & 1.634 \\
\hline${ }^{239} \mathrm{~Np}$ & 0.44 & 8.898 & 8.898 & 7.986 & 7.034 & 6.037 & 5.499 & 4.464 & 3.607 & 2.996 & 56.61 \\
\hline${ }^{238} \mathrm{Pu}$ & $\ldots$ & 1358.5 & 824.54 & 502.14 & 301.37 & 176.46 & 109.67 & 60.88 & 33.65 & 18.98 & 3386 \\
\hline${ }^{239} \mathrm{Pu}$ & -- & 180.59 & 160.07 & 143.22 & 126.85 & 109.13 & 99.95 & 81.34 & 66.09 & 54.74 & 1022 \\
\hline${ }^{240} \mathrm{Pu}$ & $\cdots$ & 263.52 & 232.61 & 207.89 & 182.97 & 157.23 & 143.09 & 116.31 & 94.10 & 77.67 & 1475 \\
\hline${ }^{241} \mathrm{Pu}$ & 38.8 & $29.8 \times 10^{3}$ & 2651.3 & 229.61 & 19.68 & 1.743 & 0.2520 & 0.0994 & 0.0722 & 0.0591 & $32.7 \times 10^{3}$ \\
\hline${ }^{242} \mathrm{Pu}$ & $\ldots$ & 0.7584 & 0.6722 & 0.6033 & 0.5343 & 0.4611 & 0.4223 & 0.3447 & 0.2801 & 0.2327 & 4.31 \\
\hline $241_{\mathrm{Am}}$ & $\cdots$ & 1740.5 & 1566.9 & 1310.7 & 1072.5 & 855.8 & 723.04 & 543.12 & 409.05 & 313.04 & 8535 \\
\hline$\underset{A m}{242 m}$ & --- & 4.621 & 3.27 & 2.33 & 1.645 & 1.129 & 0.8248 & 0.534 & 0.34 & 0.23 & 14.94 \\
\hline${ }^{242} \mathrm{Am}$ & --- & 4.62 & 3.27 & 2.33 & 1.64 & 1.13 & 0.82 & 0.54 & 0.34 & 0.23 & 14.94 \\
\hline${ }^{243} \mathrm{Am}$ & -- & 10.09 & 8.898 & 7.986 & 7.034 & 6.037 & 5.499 & 4.464 & 3.607 & 2.996 & 56.6 \\
\hline${ }^{242} \mathrm{Cm}$ & -- & 1043.8 & 2.679 & 1.697 & 1.195 & 0.8226 & 0.5985 & 0.3894 & 0.2519 & 0.1666 & 1051.6 \\
\hline${ }^{243} \mathrm{Cm}$ & -- & 1.315 & 0.1356 & 0.0616 & 0.0185 & -- & --- & -- & -- & -- & $i .53$ \\
\hline${ }^{244} \mathrm{Cm}$ & --- & 758.4 & 102.64 & 13.571 & 1.772 & 0.2247 & 0.0305 & $\cdots$ & --- & -- & 876.6 \\
\hline
\end{tabular}




\section{TABLE C-5. Total Curies Released from 1000 Year Delayed Failure}

\begin{tabular}{|c|c|c|c|c|}
\hline Isotope & $\begin{array}{l}\text { Volatile Releases from } \\
\text { Initial 1) Faled Fue) } \\
\text { (Curies) }\end{array}$ & $\begin{array}{l}\text { Release by Leaching } \\
\text { Initial l\% Failed Fuel } \\
\text { (Curies). }\end{array}$ & $\begin{array}{c}\text { Releases from } 1000 \text { year } \\
\text { Delayed Failure (99\% of Fuel) } \\
\text { (Curies) }\end{array}$ & $\begin{array}{c}\text { Tota } 1 \\
\text { (Curies) } \\
\end{array}$ \\
\hline $3_{H}$ & 15.7 & -- & -- & 15.7 \\
\hline${ }^{79} \mathrm{Se}$ & $1.3 \times 10^{-3}$ & $1.2 \times 10^{-2}$ & 1.22 & 1.23 \\
\hline${ }^{87} \mathrm{Rb}$ & -- & -- & $6.1 \times 10^{-5}$ & $6.1 \times 10^{-5}$ \\
\hline${ }^{89} \mathrm{Sr}$ & 30.1 & 3.19 & -- & 33.3 \\
\hline${ }^{90} \mathrm{Sr}$ & 23.8 & 359 & $4.65 \times 10^{-6}$ & 383 \\
\hline $90_{Y}$ & -- & 359 & $4.65 \times 10^{-6}$ & 359 \\
\hline $91_{Y}$ & -- & 7.84 & -- & 7.84 \\
\hline${ }^{93} 2 r$ & -- & $5.9 \times 10^{-2}$ & 5.86 & 5.9 \\
\hline $93 \mathrm{~m}_{\mathrm{Nb}}$ & -- & $5.34 \times 10^{-2}$ & 5.86 & 5.9 \\
\hline${ }^{95} 2 r$ & -- & 83.5 & -- & 83.5 \\
\hline${ }^{95} \mathrm{Nb}$ & -- & 162 & -- & 162 \\
\hline${ }^{99} \mathrm{TC}$ & -- & 0.45 & 44.3 & 44.8 \\
\hline${ }^{103_{\mathrm{Ru}}}$ & -- & 22.1 & -- & 22.1 \\
\hline $106_{\mathrm{Ru}}$ & -- & 663 & -- & 663 \\
\hline${ }^{107} \mathrm{Pd}$ & -- & -- & 0.341 & 341 \\
\hline $110 m_{A g}$ & -- & 0.33 & -- & 0.33 \\
\hline${ }^{160} \mathrm{~Tb}$ & -- & 0.10 & -- & 0.10 \\
\hline $166 \mathrm{~m}_{\mathrm{HO}}$ & -- & -- & $1.3 \times 10^{-4}$ & $1.3 \times 10^{-4}$ \\
\hline${ }^{238} \mathrm{Pu}$ & -- & 33.9 & 50.9 & 84.8 \\
\hline${ }^{239} \mathrm{Pu}$ & -- & 10.2 & 1270 & $1.28 \times 10^{3}$ \\
\hline${ }^{240} \mathrm{Pu}$ & -- & 14.8 & 5120 & $5.73 \times 10^{3}$ \\
\hline $241_{\mathrm{Pu}}$ & -- & 327 & 159. & 486 \\
\hline${ }^{242} \mathrm{Pu}$ & -. & $4.31 \times 10^{-2}$ & 4.32 & 4.36 \\
\hline $241_{\mathrm{Am}}$ & -- & 85.4 & $1.06 \times 10^{2}$ & 192 \\
\hline $242 m_{A m}$ & -- & 0.15 & 0.131 & 0.28 \\
\hline${ }^{243}{ }_{A m}$ & -- & 0.57 & 49.6 & 50.2 \\
\hline${ }^{242} \mathrm{Cm}$ & -- & 10.5 & 0.107 & 10.6 \\
\hline${ }^{243} \mathrm{Cm}$ & -- & $1.53 \times 10^{-2}$ & $\cdots$ & $1.5 \times 10^{-2}$ \\
\hline${ }^{244} \mathrm{Cm}$ & -- & 8.77 & $\cdots$ & 8.8 \\
\hline${ }^{245} \mathrm{Cm}$ & -- & $1.1 \times 10^{-2}$ & 0.794 & 0.80 \\
\hline${ }^{246} \mathrm{~cm}$ & -- & -- & 0.162 & 0.16 \\
\hline
\end{tabular}


TABLE C-5. Total Curies Released from 1000 Year Delayed Failure (Cont'd)

\begin{tabular}{|c|c|c|c|c|c|}
\hline Isotope & $\begin{array}{l}\text { Volatile Releases from } \\
\text { Initial } 1 \% \text { Failed Fuel } \\
\text { (Curies) }\end{array}$ & $\begin{array}{l}\text { Release by Leaching } \\
\text { Initial 1\% Failed Fuel } \\
\text { (Curies) }\end{array}$ & $\begin{array}{c}\text { Releases from } 1000 \\
\text { Delayed Failure ( } 99 \% \\
\text { (Curies) }\end{array}$ & $\begin{array}{l}\text { Year } \\
\text { of Fue 1) }\end{array}$ & $\begin{array}{c}\text { Total } \\
\text { (Curies) }\end{array}$ \\
\hline${ }^{247} \mathrm{Cm}$ & -- & -- & -- & & 0 \\
\hline $232_{U}$ & -- & -- & -- & & 0 \\
\hline $233_{U}$ & -- & -- & 0.942 & & 0.94 \\
\hline${ }^{234} U$ & -- & $4.7 \times 10^{-2}$ & 28.3 & & 28.3 \\
\hline $235 v$ & -- & -- & 0.054 & & 0.054 \\
\hline${ }^{236} \mathrm{v}$ & -- & -- & 1.05 & & 1.05 \\
\hline${ }^{237} U$ & -- & -- & $3.97 \times 10^{-3}$ & & $4.0 \times 10^{-3}$ \\
\hline $238_{u}$ & -- & -- & 0.973 & & 0.97 \\
\hline${ }^{233} \mathrm{~Pa}$ & -- & $1.6 \times 10^{-2}$ & 1.14 & & 1.2 \\
\hline${ }^{124} \mathrm{Sb}$ & 0.26 & $2.5 \times 10^{-2}$ & 28.5 & & 28.8 \\
\hline${ }^{125} 5_{S b}$ & 24.8 & 18.9 & $-\cdot$ & & 43.7 \\
\hline${ }^{126} \mathrm{Sb}$ & -- & $1.7 \times 10^{-2}$ & 1.66 & & 1.7 \\
\hline${ }^{125 \mathrm{~m}_{\mathrm{Te}}}$ & 10.0 & 7.8 & -- & & 17.8 \\
\hline${ }^{127} \mathrm{Te}$ & 18.8 & 3.2 & -- & & 22.0 \\
\hline${ }^{127 m_{\mathrm{me}}}$ & 19.1 & 3.2 & -- & & 22.3 \\
\hline${ }^{129} \mathrm{Te}$ & 13.1 & 1.1 & -- & & 14.2 \\
\hline${ }^{129 m} \mathrm{Te}$ & 20.4 & 1.7 & -- & & 22.1 \\
\hline${ }^{129} \mathrm{I}$ & -- & -- & 0.12 & & 0.12 \\
\hline${ }^{134} \mathrm{Cs}$ & 1000 & 359 & -- & & $1.36 \times 10^{3}$ \\
\hline${ }^{135} \mathrm{Cs}$ & $1 \times 10^{-3}$ & $9 \times 10^{-3}$ & 0.887 & & 0.90 \\
\hline${ }^{136} \mathrm{Cs}$ & $1 \times 10^{-2}$ & -- & -- & & $1 \times 10^{-2}$ \\
\hline${ }^{137} \mathrm{Cs}$ & 498 & 448 & $3.1 \times 10^{-5}$ & & 946 \\
\hline $140_{\mathrm{Ba}}$ & 0.13 & -- & -- & & 0.13 \\
\hline${ }^{141} \mathrm{Ce}$ & -- & 14.0 & -- & & 14.0 \\
\hline${ }^{144} \mathrm{Ce}$ & -- & 10.5 & -- & & 10.5 \\
\hline${ }^{144} \mathrm{Pr}$ & -- & 10.5 & -- & - & 10.5 \\
\hline${ }^{147}$ Nd & -- & $1.3 \times 10^{-2}$ & -- & & $1.3 \times 10^{-2}$ \\
\hline${ }^{147} \mathrm{Pm}$ & -- & 227. & -- & & 227. \\
\hline${ }^{237} \mathrm{~Np}$ & -- & $1.6 \times 10^{-2}$ & 2.2 & & 2.2 \\
\hline${ }^{239} \mathrm{Nb}$ & -- & 0.57 & 54.9 & & 55.5 \\
\hline
\end{tabular}


TABLE C.6. Volatile Releases

from $1 \%$ Failed Fuel

\begin{tabular}{ll} 
Isotope & $\begin{array}{c}\text { Volatile Release from } \\
\text { Diffusion (In-Reactor) } \\
\text { (Curies) }\end{array}$ \\
\cline { 2 - 2 }${ }^{89} \mathrm{Sr}$ & 30.1 \\
${ }^{90} \mathrm{Sr}$ & 23.8 \\
${ }^{124} \mathrm{Sb}$ & 0.264 \\
${ }^{125} \mathrm{Sb}$ & 24.8 \\
${ }^{126} \mathrm{Sb}$ & $(\mathrm{a})$ \\
${ }^{125 \mathrm{~m}_{\mathrm{Te}}}$ & 10.0 \\
$127 \mathrm{Te}$ & 18.8 \\
$127 \mathrm{~m}_{\mathrm{Te}}$ & 19.1 \\
$129 \mathrm{Te}$ & 13.1 \\
$129 \mathrm{~m}_{\mathrm{Te}}$ & 20.4 \\
$129 \mathrm{I}$ & $1.2 \times 10^{-4}$ \\
$134 \mathrm{Cs}$ & 999.8 \\
$135 \mathrm{Cs}$ & $1 \times 10^{-3}$ \\
$136 \mathrm{Cs}$ & $1 \times 10^{-2}$ \\
$137 \mathrm{Cs}$ & 497.6 \\
$140 \mathrm{Ba}$ & 0.13 \\
${ }^{79} \mathrm{Se}$ & $1.3 \times 10^{-3}$ \\
$\left.1{ }^{12}\right)_{\mathrm{Very}}$ &
\end{tabular}

TABLE C-7. Cesium Leached from 1\% Failed Rods

$\begin{array}{ccccccccccc}\text { Isotope } & \underline{50 \mathrm{yr}} & \underline{100 \mathrm{yr}} & \underline{150 \mathrm{yr}} & \underline{200 \mathrm{yr}} & \underline{250 \mathrm{yr}} & \underline{300 \mathrm{yr}} & \underline{350 \mathrm{yr}} & \underline{400 \mathrm{yr}} & \underline{450 \mathrm{yr}} & \underline{\text { Total }} \\ { }^{134} \mathrm{Cs} & 359.4 & \text { (a) } & \text { (a) } & \text { (a) } & \text { (a) } & \text { (a) } & \text { (a) } & \text { (a) } & \text { (a) } & 359.4 \\ { }^{135} \mathrm{Cs} & 1.34 \times 10^{-3} & 1.19 \times 10^{-3} & 1.07 \times 10^{-3} & 9.5 \times 10^{-4} & 8.2 \times 10^{-4} & 7.5 \times 10^{-4} & 6.1 \times 10^{-4} & 5 \times 10^{-4} & 4.1 \times 10^{-4} & 9 \times 10^{-3} \\ { }^{137} \mathrm{Cs} & 321.6 & 91.0 & 25.7 & 7.2 & 1.9 & 0.6 & \cdots & \cdots & \cdots & 448\end{array}$

(a)Insignificant amounts. 


\section{C.3 SOLUTION TO THE BOOTH MODEL}

The solution to the Booth diffusion model for stable or long-lived fission products is given by the following equation:

$$
F=1-\frac{1}{T}+\frac{6}{\pi 4 T} \sum_{n=1}^{n=\infty} \frac{\exp \left(-n \pi^{n_{m}}\right)}{\pi 4}
$$

where

$$
\begin{aligned}
& F=\text { release fraction, } \\
& T=D^{\prime} t, \\
& \text { and } \quad D^{\prime}=D_{0} / a^{2} \exp (-Q / R T) \text {, } \\
& t=\text { time, sec, } \\
& \mathrm{D}_{0} / \mathrm{a}^{2}=\text { diffusion constant, } \mathrm{sec}^{-1} \text {, } \\
& Q=\text { activation energy, } \mathrm{kcal} / \mathrm{mole} \text {, } \\
& \mathrm{R}=\text { gas constant, } \\
& T=\text { temperature, }{ }^{\circ} \mathrm{K}
\end{aligned}
$$

Parker ${ }^{(1)}$ has measured the diffusion coefficients of cesium and iodine for the above model to be $D_{0} / a^{2}=1.37 \mathrm{sec}^{-1}$ and $Q=52.3 \mathrm{Kcal} / \mathrm{mole}$, and $D_{0} / \mathrm{a}^{2}=$ $2.94 \mathrm{sec}^{-1}$ and $Q=58.7 \mathrm{Kcal} / \mathrm{mole}$, respectively. He has recommended that the $D^{\prime}$ values calculated from the above equations and numbers be adjusted by two correction factors. The first is to correct for the "burst effect" which is inherent in his post-irradiation annealing data. This correction factor is:

$$
8.8793 \times 10^{-4} \exp \left(-0.91756 \times 10^{4} / \mathrm{T}\right) \text {. }
$$

The second is a correction for the burnup effect which is observed for the gaseous fission products and is expressed in the following manner:

$$
\exp \left[2.303\left(\frac{\mathrm{MWd} / \mathrm{T}}{25,000}-1\right)\right]
$$

This effect is thought to be related to bubble linkup along grain boundaries and resulting in a decrease in the diffusion length.

The corrected diffusion coefficient can thus be expressed in the following manner:

$$
\begin{aligned}
& D^{\prime}(\text { corrected })=D_{0} / a^{2} \exp (-Q / R T) 8.8793 \times 10^{-4} \exp \left(-0.91756 \times 10^{-4} / T\right) \\
& \exp \left[2.303\left(\frac{M W d / T}{25,000}-1\right)\right]
\end{aligned}
$$




\section{C. $4 \quad \underline{U O}_{2}$ LEACH RATES}

The estimate of $\mathrm{UO}_{2}$ leach rates in sea water has been taken from an experiment $^{(2)}$ where highly irradiated, $\sim 54,000 \mathrm{MWd} / \mathrm{MTM}, \mathrm{UO}_{2}$ (enriched $3-5 \%$ ) was placed in both distilled water and Hanford ground water for 60 days. The leach rates of several radioactive isotopes were measured for this time period as shown in Figures C.1 and C.2. The leach rate amount in grams of $\mathrm{UO}_{2}$ is that amount of $\mathrm{UO}_{2}$ fuel containing the amount of the isotope leached away. For example, to get the amount of a particular isotope leached away per $\mathrm{cm}^{2}$ per day at a particular time the value taken from either Figure C.1 or C.2 would be multiplied by the amount of the isotope in $1 \mathrm{~g}$ of fuel (i.e., $2.4 \times 10^{-6} \mathrm{~g} \mathrm{UO}_{2} / \mathrm{cm}^{2}$ day $\times 4.87 \times 10^{-5} \mathrm{Ci}^{241} \mathrm{Am} / \mathrm{g} \mathrm{UO}_{2}=1.22 \times 10^{-10} \mathrm{Ci}$ ${ }^{241} \mathrm{Am} / \mathrm{cm}^{2}$ day).
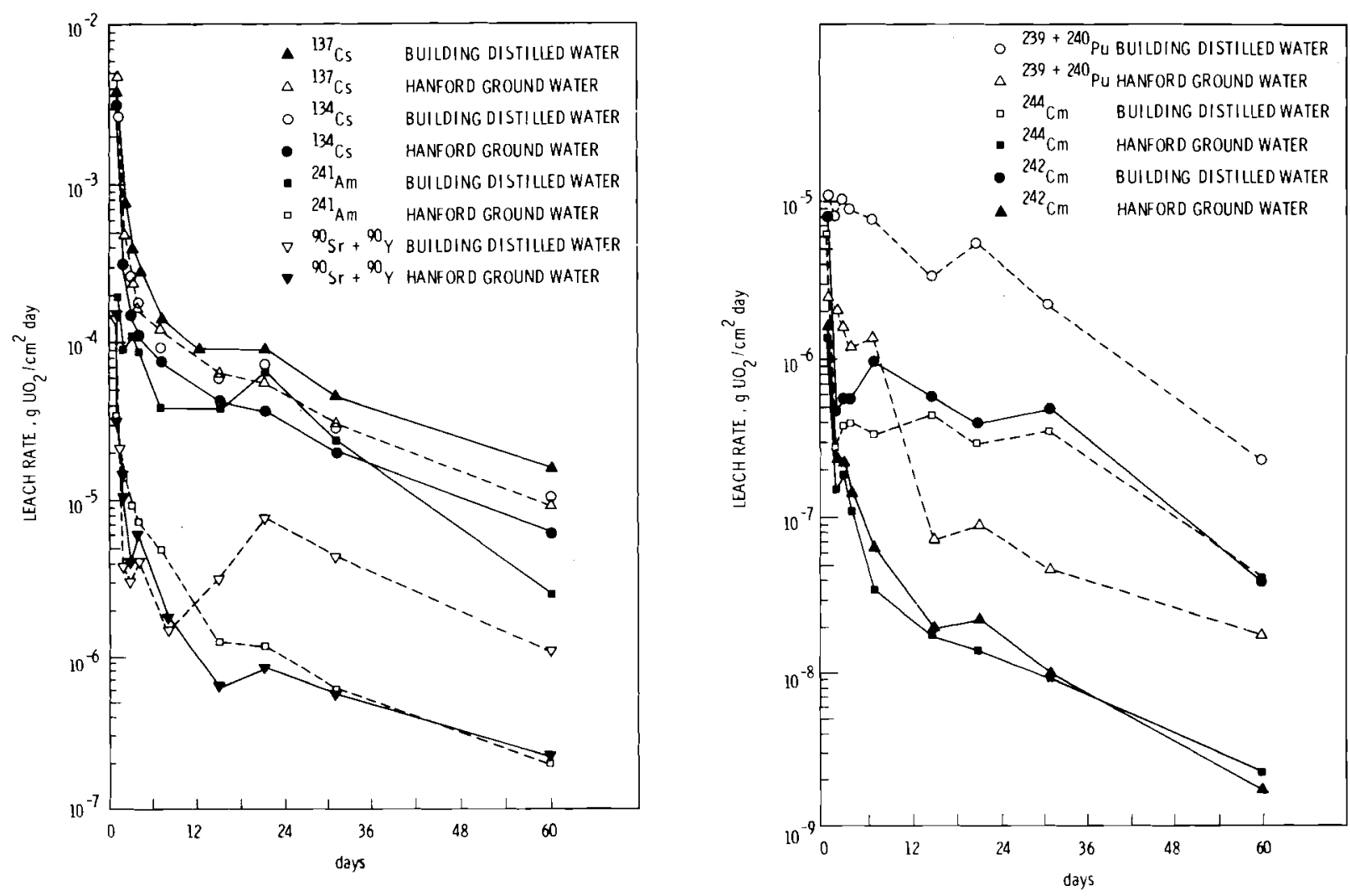

FIGURES C.1 and C.2. Leach Rates of Radioactive Isotopes from an Enriched $\mathrm{UO}_{2}$ Pellet Irradiated to 54,000 Mwd/MTM 
The data in Figures $C .1$ and $C .2$ show a significant drop in leach rates with time (in most cases more than 2 orders of magnitude in the 60-day period). This drop probably occurs because these isotopes are more easily leached than the base material $\left(\mathrm{UO}_{2}\right)$ and thus become selectively leached initially at a fast rate. Eventually an equilibrium leach rate will be obtained which will be dependent on the leach rate of the $\mathrm{UO}_{2}$ base material.

Figures C.1 and C.2 also show higher leach rates for the distilled water versus the groundwater. This is most likely due to the effect of pH. Distilled water in contact with air typically has a $\mathrm{pH}$ near 5 because of $\mathrm{CO}_{2}$ from air, while Hanford groundwater is slightly basic with a $\mathrm{pH} \sim 7.5$ to 8 . Sea water is also slightly basic, $\mathrm{pH}$ 28.3, but has a much higher salt content than Hanford goundwater. However, there are no specific species present within sea water that would be expected to appreciably affect leach rates of $\mathrm{UO}_{2}$, and the $\mathrm{pH}$ of the water will likely have the more dominant effect on leach rates. (a) Consequently, it would be expected that the leach rates of $\mathrm{UO}_{2}$ in sea water would be similar to those in Hanford ground water. However, to maintain conservatism for the release rate we will use the higher leach rates for distilled water in our analysis.

As a result of the relatively short time period over which the data were taken, we cannot accurately estimate the long term leach rates for the base material $\mathrm{UO}_{2}$. Therefore, further conservatisms must be made to maintain an upper bound on release. It has been assumed that the long term leach rates of the $\mathrm{UO}_{2}$ (out to 450 years), are the same as those measured for the ${ }^{137} \mathrm{Cs}$ isotope in distilled water at 60 days. This isotope has shown the largest amount of selective leaching. This is most likely a very conservative assumption because, as discussed earlier, the $\mathrm{UO}_{2}$ leach rates are expected to be significantly less than the selectively leached values observed from the short-term data used in this analysis. For the integral amount leached during the first year we have used the integral leach rates given in Figures $c .1$ and $C .2$ for 0 to 60 days and the leach rates at 60 days for the remaining 60 to 365 days. For those radioactive isotopes not given in Figures $c .1$ and $C .2$ we have assumed they are leached at the same integral rate as the ${ }^{137}$ Cs isotope.

(a)J. L. Ryan, memorandum to C. E. Beyer, March 19, 1976. 


\section{REFERENCES}

1. Parker, G. W., Calculation of Gap Release of Radioactive Fission Products, WASH-1400, (NUREG 75/014) Appendix C of Appendix VII to Reactor Safety Study, October 1975.

2. Katayama, B. Y., Leaching of an Irradiated Fuel Pellet in Deionized Typical Ground Water, BNWL-2057, Battelle, Pacific Northwest Laboratories, Richland, WA (to be published). 


\section{APPENDIX D}

\section{DOSE MODELING}

The general relation which was used to estimate the population dose from contaminated fish or seafood consumption is for the radionuclide $i$. (1)

$$
D_{i}=C_{i} U_{p} B_{i}(D F)_{i}
$$

where $\quad C_{i}=$ concentration of $i$ th radionuclide in water,

$B_{i}=$ concentration factor of $i$ th nuclide in marine organism $(1)$

$U_{p}=$ annual consumption of contaminated seafood by total population,

$(D F)_{i}=$ factor relating dose to amount of radionuclide $i$ ingested $(1,2,3)$

The annual consumption, $U$, is limited by the productivity, P; i.e., the amount of fish or seafood which may be caught in an area of the sea in one year from the surface down to the sea floor. If we assume that one-half of this productivity is eaten by man, then

$$
U_{p}=(1 / 2) P A d
$$

where

$$
\begin{aligned}
& A=\text { area of sea with productivity } P, \text { and } \\
& d=\text { the average depth of the sea at that location. }
\end{aligned}
$$

But the concentration of a particular radionuclide $i$ is simply

$$
c_{i}=\frac{Q_{i}}{V}
$$

where $\quad Q_{i}=$ the total release into water of radionuclide $i$, and

$V=$ the volume of sea water in whicn the nuclide is diluted.

Substituting Equations D.2 and D.3 into D.1, we obtain

$$
D_{i}=\frac{Q_{i}}{V}(1 / 2) P A d B_{i}(D F)_{i}
$$


Now for our purposes of dose estimation, let us assume that the dilution volume and the volume in which the productivity is defined are identical, thus

$$
V=A d
$$

and, therefore, Equation D. 1 becomes

$$
D_{i}=(1 / 2) Q_{i} P B_{i}(D F)_{i}
$$

Thus, the dose is independent of radionuclide concentration which precludes the necessity of estimating concentration at points or regions around the release point, which is in itself a vary arduous task ${ }^{(4)}$ as shown in Table D.1.

TABLE D.1. NuClide Dependent Parameters Use for Dose Calculation (Equation D.5)

T. Body Dose

\begin{tabular}{|c|c|c|c|c|c|}
\hline \multirow[b]{2}{*}{ Nuclide } & \multirow{2}{*}{$\frac{\mathrm{man-rem}}{\mathrm{ci} / \mathrm{yr}}$} & \multicolumn{4}{|c|}{$(\mathrm{Ci} / \mathrm{kg}$ per $\mathrm{C} i / \mathrm{l})$} \\
\hline & & Fish & Crustacea & Mol1uscs & Reference \\
\hline $126 \mathrm{Sb}$ & $3.99 \times 10^{2}$ & 1000 & 1000 & 1000 & Freke ${ }^{(5)}$ \\
\hline${ }^{134}{ }_{C s}$ & $8.49 \times 10^{4}$ & 30 & 50 & 10 & Freke $^{(5)}$ \\
\hline${ }^{137+D_{C S}}(b)$ & $4.70 \times 10^{4}$ & 30 & 50 & 10 & Freke ${ }^{(5)}$ \\
\hline $233+D_{U}$ & $3.70 \times 10^{4}$ & 10 & 10 & 10 & UCRL (derived) ${ }^{(6)}$ \\
\hline $234 U$ & $3.62 \times 10^{4}$ & 10 & 10 & 10 & UCRL (derived) ${ }^{(6)}$ \\
\hline $236_{U}$ & $3.48 \times 10^{4}$ & 10 & 10 & 10 & UCRL (derived) ${ }^{(6)}$ \\
\hline $237_{U}$ & $1.43 \times 10^{1}$ & 10 & 10 & 10 & UCRL (derived) $(6)$ \\
\hline $238+D_{U}$ & $1.10 \times 10^{6}$ & 10 & 10 & 10 & UCRL (derived) $(6)$ \\
\hline${ }^{238} \mathrm{Pu}$ & $8.32 \times 10^{3}$ & 3 & 200 & 200 & UCRL (measured) ${ }^{(6)}$ \\
\hline${ }^{239} \mathrm{Pu}$ & $9.27 \times 10^{3}$ & 3 & 200 & 200 & UCRL (measured) ${ }^{(6)}$ \\
\hline${ }^{240} \mathrm{Pu}$ & $9.27 \times 10^{3}$ & 3 & 200 & 200 & UCRL (measured) ${ }^{(6)}$ \\
\hline $241+D_{\mathrm{Pu}}$ & $1.51 \times 10^{2}$ & 3 & 200 & 200 & UCRL (measured) $(6)$ \\
\hline $241_{A m}$ & $2.63 \times 10^{4}$ & 25 & 1000 & 1000 & UCRL (derived) ${ }^{(6)}$ \\
\hline $243_{\mathrm{Am}}$ & $2.68 \times 10^{4}$ & 25 & 1000 & 1000 & UCRL (derived) ${ }^{(6)}$ \\
\hline
\end{tabular}
Commitment Factor

(a) These values revised September 9, 1976.

(b) The notation $+D$ indicates that the dose contribution from daughters after intersection is included. 
It is assumed that the fish are distributed randomly within the ocean volume so that there is no correlation between density of fish and concentration of radionuclides.

The doses are estimated assuming the contaminated fish are consumed for one year only and noncontaminated foods eaten thereafter. However, the population is exposed for 49 additional years to the nuclide slowly being eliminated from their bodies. The dose from this total exposure has been calculated and is called the "50-year dose commitment".

The release over the 450 years was assumed for calculational purposes to occur over one year in order to estimate a dose value. The resulting population dose is over 450 years, and so does not apply to one set of individuals, but to many generations over 450 years. However, since most of the nuclides are released in the first year, this release affects only one generation of individuals. The 1000-year delayed release was also treated in this manner. 
I 


\section{REFERENCES}

1. Soldat, J. K., N. M. Robinson and D. A. Baker, Models and Computer Codes for Evaluating Environmental Radiation Doses, BNWL-1754, BatteTle Pacific Northwest Laboratories, Richland, WA, February 1974.

2. Soldat, J. K., Modeling of Environmental Pathways and Radiation Doses from Nuclear Facilities, BNWL-SA-3939, Battelle Pacific Northwest Laboratories, Richland, WA, October 1971.

3. Burkholder, H. C., M. D. Cloninger, D. A. Baker and G. Jansen, Incentives for Partitioning High-Level Waste, BNWL-1927, Battelle Pacific Northwest Laboratories, Richland, WA, November 1975.

4. Pritchard, D. W., R. 0. Reid, A. Kubo, H. H. Carter, "Physical Processes of Water Movement and Mixing", Radioactivity in the Marine Environment, National Academy of Sciences, 1971 .

5. Freke, A. M., "A Model for the Approximate Calculation of Safe Rates of Discharge of Radioactive Wastes into Marine Environments", Health Physics. 13:743-758, 1967.

6. Thompson, S. E., C. A. Burton, D. J. Quinn and Y.C. Ng, Concentration Factors of Chemical Elements in Edible Aquatic Organisms, UCRL-50564 Rev. 1, Lawrence Livermore Laboratory, Livermore, CA, October 10, 1972. 
.

. 


\section{DISTRIBUTION}

No. of

Copies

OFFSITE

A. A. Churm

U.S. DOE Chicago Patent Group

Chicago Operations Office

9800 South Cass Avenue

Argonne, IL 60439

163 U.S. DOE Technical Information Center

K. A. Trickett

U.S. DOE Division of Reactor Development and Demonstration

U.S. DOE Headquarters

Germantown, MD 20014

25 W. Brobst

U.S. DOE Division of Environmental Control Technology

Transportation Branch

U.S. DOE Headquarters

Washington, DC 20545

J. Counts

U.S. DOE Division of Environmental Control Technology

Transportation Branch

U.S. DOE Headquarters

Washington, DC 20545

M. Chais

U.S. DOE Division of Environmental Control Technology

Transportation Branch

U.S. DOE Headquarters

Washington, DC 20545

R. Garrison

U.S. DOE Division of Environmental Control Technology

Transportation Branch

U.S. DOE Headquarters

Washington, DC 20545
No. of

Copies

J. A. Sisler

U.S. DOE Division of Environmental

Control Technology

Transportation Branch

U.S. DOE Headquarters

Washington, DC 20545

R. M. Moser

U.S. DOE Chicago Operations Office 9800 South Cass Avenue

Argonne, IL 60439

W. G. O'Quinn

U.S. DOE Savannah River Operations Office

P.0. Box A

Aiken, SC 29801

N. Stetson

U.S. DOE Savannah River Operations Office

P.0. Box A

Aiken, SC 29801

L. L. Turner

U.S. DOE Savannah River Operations Office

P.0. Box A

Aiken, SC 29801

D. Davis

U.S. DOE Albuquerque Operations Office

P.0. Box 5400

Albuquerque, NM 87115

J. A. Lamb

U.S. DOE Oak Ridge Operations Office P.0. Box E

Oak Ridge, TN 37830 
No. of

Copies

J. J. Schreiber

U.S. DOE Oak Ridge Operations Office

P.0. Box E

Oak Ridge, TN 37830

R. C. Dove

University of California

Los Alamos Scientific Laboratory

P.0. Box 1663

Los Alamos, NM 87545

T. K. Keenan

University of California

Los Alamos Scientific Laboratory

P.0. Box 1663

Los Alamos, NM 87545

T. A. Butler

University of California

Los Alamos Scientific Laboratory

P.0. Box 1663

Los Alamos, NM 87545

W. C. Bright

U.S. DOE Albuquerque Operations Office

Rocky Flats Area Office

P.0. Box 928

Golden, C0 80401

L. Benner

Nationa 1 Transportation Safety Board

Washington, DC 20594

A. L. Schmieg

National Transportation Safety Board

Washington, DC 20594

J. Power

Westinghouse Electric Corp.

P.0. Box 355

Pittsburgh, PA 15230
No. of

Copies

P. J. Eicker

Sandia Laboratories, Livermore

Livermore, CA 94550

J. W. Langhaar

E. I. Dupont de Nemours \& Company Savannah River Plant

Aiken, SC 29801

J. Curtis

Department of Transportation

Materials Transportation Bureau

2100 Second St. S.W.

Washington, DC 20590

A. Grella

Department of Transportation

Materials Transportation Bureau

2100 Second St. S.W.

Washington, DC 20590

W. Rowe

Environmental Protection Agency

401 M. Street

Washington, DC 20460

A. J. Nertney

Aerojet Nuclear Company

550 2nd St.

Idaho Fal1s, ID 83401

R. G. Bradley

U.S. DOE Division of Nuclear Fuel

Cycle and Production

U.S. DOE Headquarters

Germantown, MD 20014

C. Starr

Electrical Power Research Inst.

P.0. Box 10412

Palo Alto, CA 94304

C. Comar

Electrical Power Research Inst.

P.0. Box 10412

Palo Alto, CA 94304 
No. of

Copies

E. Zebrowksi

Electrical Power Research Inst.

P.0. Box 10412

Palo Alto, CA 94034

Ichiro Yabe

Japan Nuclear Safety Research Association

Room 1037, National Press Bidg.

14 th and $F$ Streets NW

Washington, DC 20004

G. W. Cunningham

Asst. Admin. for Nuclear Energy U.S. DOE

Washington, DC 20545

J. L. Russell

Office of Radiation Programs

AW-459, EPA

401 M. St. S.W.

Washington, DC 20460

R. Williams

Electrical Power Research Inst.

P.0. Box 10412

Palo Alto, CA 94304

Combustion Engineering, Inc.

Windsor, CT 06095

J. Desmond

Babcock \& Wilcox, Co.

P.0. Box 1260

Lynchburg, VA 24505

C. Woods

Babcock \& Wilcox Co.

P. 0. Box 1260

Lynchburg, VA 24505

Prof. liorian C. Rasmussen

Massachusetts Institute of

Technology

Cambridge, MA 02139
No. of

Copies

L. Bonzon

Sandia Laboratories

P.0. Box 5800

Albuquerque, NM 87115

J. K. Cole

Sandia Laboratories

P.0. Box 5800

Albuquerque, NM 87115

J. T. Foley

Sandia Laboratories

P.0. Box 5800

Albuquerque, NM 87115

J. Freedman

Sandia Laboratories

P.0. Box 5800

Albuquerque, NM 87115

W. F. Hartmann

Sandia Laboratories

P.0. Box 5800

Albuquerque, NM 87115

R. M. Jefferson

Sandia Laboratories

P.0. Box 5800

Albuquerque, NM 87115

R. Luna

Sandia Laboratories

P.0. Box 5800

Albuquerque, NM 87115

T. G. Priddy

Sandia Laboratories

P.0. Box 5800

Albuquerque, NM 87115

A. W. Snyder

Sandia Laboratories

P.0. Box 5800

Aibuquerque, NM 87115

D. S. Moulder

Marine Biological Association

UNITED KINGDOM 
No. of

Copies

R. Yoshimura

Sandia Laboratories

P.0. Box 5800

Albuquerque, NM 87115

H. C. Thompson

2030 M. St. N.W.

Washington, DC 20036

R. F. Barker

Nuclear Regulatory Commission

Washington, DC 20555

C. B. Bartlett

Nuclear Regulatory Commission

Washington, DC 20555

S. H. Hanauer

Nuclear Regulatory Commission

Washington, DC 20555

S. Levine

Nuclear Regulatory Commission Washington, DC 20555

R. B. Minogue

Nuclear Regulatory Commission

Washington, DC 20555

C. MicDonald

Nuclear Regulatory Commission

Washington, DC 20555

D. A. Nussbaumer

Nuclear Regulatory Commission Washington, DC 20555

W. E. Vesely

Nuclear Regulatory Commission Washington, DC 20555

I. Wall

Nuclear Regulatory Conmission Washington, DC 20555
No. of

Copies

M. J. Steindler

Argonne National Laboratory

9700 South Cass Avenue

Argonne, IL 60439

S. J. Basham

Battelle Memorial Institute

Columbus Operations

$505 \mathrm{King}$ Avenue

Columbus, $\mathrm{OH} 43201$

E. C. Lusk

Battelle Memorial Institute

Columbus Operations

505 King Avenue

Columbus, $\mathrm{OH} 43201$

R. A. Robinson

Battelle Memorial Institute

Columbus Operations

505 King Avenue

Columbus, $\mathrm{OH} 43201$

Atomics International

8900 Desoto Avenue

Conoga Park, CA 91304

A. L. Kaplan

General Electric Co.

Nuclear Fuel Division

P.0. Box 780

Wilmington, NC 28401

G. Lapier

Babcock \& Wilcox, Co.

Apo 110, PA 15613

D. Pence

General Atomic

P.0. Box 92138

San Diego, CA 92138

R. D. Seagren

Union Carbide Corporation

Oak Ridge National Laboratories

P.0. Box X

Oak Ridge, TN 37830 
L. Shappert

Union Carbide Corporation

Oak Ridge National Laboratories

P.0. Box $X$

Oak Ridge, TN 37830

J. Duckworth

Nuclear Fuel Services, Inc.

P.0. Box 124

West Valley, NY 14171

G. L. Stukenbroeker

N. L. Industries, Inc.

Nuclear Transportation Department

919 Market St., Suite 1701

Wilmington, DE 19801

H. G. Sheaty

Bureau of Radiological Health

South Carolina Department of Health and Environmental Control

Columbia, SC 29405

J. S. Corbett

ChemNuclear Systems, Inc.

P.0. Box 1866

Bellevue, WA 98009

J. A. Hebert

Battelle Seattle Research Center

P.0. Box 5395

Seattle, WA 98105

P. T. Tuite

Hittman Nuclear and Development Corporation

9190 Red Branch Rd.

Columbia, MD 21045

D. A. Edling

Mound Laboratories

P.0. Box 32

Miamisburg, $\mathrm{OH} 45342$
J. W. Doty

Mound Laboratories

P.0. Box 32

Miamisburg, $\mathrm{OH} 45342$

D. Okrent

Department of Engineering and Applied Science

University of California

Los Angeles, CA 90024

M. Gordon

Atomic Industrial Forum

7101 Wisconsin Ave.

Washington, DC 20014

A. L. Babb

Department of Nuclear Engineering

Benson Hall

University of Washington

Seattle, WA 98195

W. S. Fellows

Southern Interstate Nuclear Board

7 Dunwoody Park, Suite 104

AtTanta, GA 30341

D. G. Maxwe 11

N. L. Industries

Nuclear Division

111 Broadway

New York, NY 10006

W. R. Teer

Transnuclear Inc.

One N. Broadway

White Plains, NY 10601

S. Hartwig

Battelle Institute, e.v.

Am Romerhof 35

600 Frankfurt Ma in 90

GERMANY 
No. of

Copies

Gerald R. Swindell

International Atomic Energy Agency

A-1011 Vienna

AUSTRIA

G. Kinchin

UKAEA

Risley, Lancaster

ENGLAND

E. J. Wilson

Department of Transportation

Dangerous Goods Branch

2 Marsham St.

London SW 1

ENGLAND

Dr. Josef Jaquemin

Office of Minister für Arbeit, Gesundheit and Sociales des Landes, NRW

Landeshaus

4000 Dusseldorf

FED. REPUBLIC OF GERMANY

M. Stammler

Battelle Institute, e.v.

Am Romerhof 35

600 Frankfurt Main 90

GERMANY

R. S. Lowrie

Union Carbide Corporation

Office of Waste Isolation

P.0. Box $Y$

Oak Ridge, TN 37930

D. Turner

Union Carbide Corporation

office of Waste Isolation

P.0. Box $Y$

Oak Ridge, TN 37830

S. C. Cohn

Teknekron

4701 Sangamore Rd.

Washington, DC 20016
No. af

Copies

I. N. Lafontaine

Belgonucleaire

Rue du Champ de Mars 25

B-1050 Buxe17es

BELGIUM

K. R. Shultz

Atomic Energy Control Board

P.0. Box 1046

Ottawa KIF $5 S 9$

CANADA

W. R. Taylor

Atomic Energy of Canada Ltd.

Chalk River Laboratories

Chalk River, Ontario K0JIJ0

CANADA

$Y$. Sousselier

CEA/CEN

B.P. No. 6

F-92260 Fontenay-aux-Roses

FRANCE

W. K. Baskin

Industrial Health Branch

Division of Public Health

Box "M"

Balboa Heighrs, Canal Zone

H. Hubner

Bundesanstalt für Materialprufung

Unter den Eichen 87

$0-1000$ Berlin 45 (West)

FED. REPUBLIC OF GERMANY

B. Schulz-Forberg

Bundesanstalt für Materialprufung

Unter den Eichen 87

D-1000 Berlin 45 (West)

FED. REPUBLIC OF GERMANY

R. G. Deshparide

Isotope Division

Bhabha Atomic Research Centre

Trombay, Bombay 400085

INDIA 
No. of

Copies

S. Aoki

Research Laboratory for Nuclear Reactors

Tokyo Institute of Technology

Ookayama, Meguroku, Tokyo 152 JAPAN

G. D. Bell

United Kingdom Atomic Energy Authority

Safety and Reliability

Directorate

Warrington WA3 4NE

UNITED KINGDOM

A. Onedera

Hitachi Shipbuilding and

Engineering Co., Ltd.

5-4 Sakurajima, Kitano-cho

Konohana-ku, Osaka-shi

JAPAN

K. Ikeda

Science and Technology Agency

2-2-1 Kasumigaseki,

Chiyoda-ku, Tokyo

JAPAN

M. Tomlinson

White Shell Nuclear Research Establishment

Pinewa, Manitoba ROE ILO

CANADA

S. A. Mayman

Fuel Recycle Waste

Management Program

Whiteshell Nuclear Research Establ ishment

Pinewa, Manitoba ROE ILO

CANADA

Dr. F. Girardi

Euratom

21020 Centro Euratomdi

Ispra (Varesse)

ITALY
No. of

Copies

E. J. Wilson

Department of Transport

2 Marsham St. London SWIP 3EB

ENGLAND

Ake Hultgren

AB Atomenergi, Studsvik

Fack

S-611 ol Nyköping 1

SWEDEN

B. Gustafson

$\%$ Ake Hultgren

AB Atomenergi, Studsvik

Fack

S-61 1 o1 Nyköping 1

SWEDEN

Dr. Schmidt-Kuester

Beim Bundesminister für

Forschung and Technologie

Stresemannstrasse 2

5300 Bonn

GERMANY

W. J. Shelley

Kerr-McGee Corporation

Oklahoma City, OK 73071

R. W. Peterson

All ied General Nuclear Services

P.0. Box 847

Barnwell, SC 29812

A. Carson

General Electric Company

175 Curtner Avenue

San Jose, CA 95125

R. A. Koynenburg

University of California

Lawrence Livermore Laboratories

P.0. Box 808

Livermore, CA 94551 
No. of

Copies

\section{H.E.H.S. Wardelmann IMCO \\ 101-104 Piccadilly London WIV OAE \\ ENGLAND}

R. Berlin

Dames \& Moore

White Plains, NY 10601

W. E. Pollock

Oregon Department of Energy

Salem, OR 97301

K. Woods

Oregon Department of Energy

Salem, OR 97301

W. M. Rogers

Western Interstate Nuclear Board

1300 Carr

Denver, CO 80226

G. P. Jones

University of Southern

California

University Park

Los Angeles, CA 90007

L. L. Philipson

University of Southern California

University Park

Los Angeles, CA 90007

C. V. Hodges

Holmes \& Narver

400 E. Orangethrope Ave.

Anaheim, CA 92801

E. A. Straker

Science Applications, Inc.

P.0. Box 2351

La Jolla, CA 92038
No. of

Copies

R. C. Erdman

Science Applications, Inc.

2680 Hanover St.

Palo Alto, CA 94304

A. Unione

Science Applications, Inc.

2680 Hanover St.

Palo Alto, CA 94304

G. Waymire

Exxon Nuclear Company, Inc.

P.0. Box 3990

MS 8A-68

Seattle, WA 98124

R. Dyer

Environmental Protection Agency

Washington, DC 20460

K. Tamura

Manager, Atomic Power Department

Kimura Chemical Plants Co., LTD

1-1 Ueshima, Kuise

Amagasaki, 650

JAPAN

H. Akiyama

Senior Project Engineer

Plutonium Conversion Laboratory Construction Office Tokai Works

Tokai-Mura Ibaraki - Ken

JAPAN

0 . Terada

Applied Mechanics Section

Mitsui Engineering \& Shipbuilding Co., LTD

Tamano Works

16-1 Tamahara 3-Chome, Tamano JAPAN 
No. of

Copies

ONSITE

U.S. DOE Richland Operations Office Programs Division

H. E. Ransom

6 U.S. DOE Richland Operations

T. A. Bauminan

W. A. Burns

R. B. Goranson

P. E. Lamont

J. M. Peterson

D. J. Squires

3 Rockwell Hanford Operations

W. G. Bevan

W. M. Harty

D. D. Woodrich

3 United Nuclear Industries, Inc.

J. A. Adams

P. A. Crosetti

T. E. Dabrowski

2 Washington Public Power Supply System

G. F. Bailey

J. B. Vetrano

2 Exxon Nuclear Company, Inc.

R. Nilsen

R. K. Robinson

2 Hanford Engineering Development Laboratory

A. W. DeMerschman

C. E. Beyer
No. of

Copies

55 Battelle-Northwest

W. B. Andrews

W. J. Bair

D. A. Baker

C. L. Brown

S. H. Bush

N. E. Carter

J. G. DeSteese

H. K. Elder

L. G. Faust

J. R. Friley

R. J. Hall

H. Harty

25 S. W. Heaberlin

H. L. Henry

J. F. Johnson

W. S. Kelley

S. N. Liu

E. S. Murphy

P. L. Peterson

R. E. Rhoads

F. A. Simonen

E. C. Watson

R. D. Widrig

L. D. Williams

W. K. Winegardner

Technical Information (5)

Technical Publications 


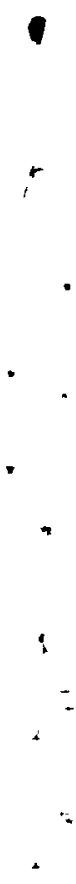

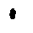

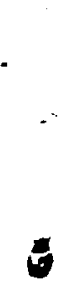

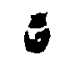

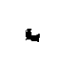

